NRRI 96-12

\title{
ANTITRUST CONCERNS IN THE MODERN PUBLIC UTILITY ENVIRONMENT
}

\author{
James E. Meeks \\ Professor of Law \\ The Ohio State University \\ College of Law \\ THE NATIONAL REGULATORY RESEARCH INSTITUTE \\ 1080 Carmack Road \\ Columbus, Ohio 43210 \\ $614 / 292-9404$
}

April 1996

This report was prepared by The National Regulatory Research Institute (NRRI) with funding provided by participating member commissions of the National Association of Regulatory Utility Commissioners (NARUC). The views and opinions of the author do not necessarily state or reflect the views, opinions, or policies of the NRRI, the NARUC, or NARUC member commissions. 


\section{DISCLAIMER}

Portions of this document may be illegible in electronic image products. Images are produced from the best available original document. 


\section{DISCLAIMER}

This report was prepared as an account of work sponsored by an agency of the United States Government. Neither the United States Government nor any agency thereof, nor any of their employees, make any warranty, express or implied, or assumes any legal liability or responsibility for the accuracy, completeness, or usefulness of any information, apparatus, product, or process disclosed, or represents that its use would not infringe privately owned rights. Reference herein to any specific commercial product, process, or service by trade name, trademark, manufacturer, or otherwise does not necesarily constitute or imply its endorsement, recommendation, or favoring by the United States Government or any agency thereof. The views and opinions of authors expressed herein do not necessarily state or reflect those of the United States Government or any agency thereof. 


\section{EXECUTIVE SUMMARY}

Direct regulation of public utility activity and behavior has been the predominant approach to protect the public interest in this country. Changes in technology, as well as new thinking about the optimum role of regulation, have created a changing atmosphere in all of the traditional public utility industries. Competitive markets for many of the products and services in these industries have been developing. While monopoly power will continue to exist in certain parts of these industries and require direct regulation, in many areas a growing reliance upon competition as the best method of serving the public interest is developing.

With this shift in emphasis from regulation to free markets, the antitrust laws take on new importance for these industries. In the absence of direct regulatory control, those laws are our society's primary method of insuring the markets necessary to make competition an effective device for protecting the public interest.

This study provides an overview of the antitrust laws, briefly describes the applicable theoretical underpinnings, and then turns to areas where public utility activity may pose special problems or conflicts with prevailing antitrust policy. The following problems and related cases are discussed.

(1) Recent cases have tended to downplay the antitrust significance of price squeezes and predatory pricing for both theoretical and practical reasons, particularly where all the prices involved are subject to direct regulation. However, it is recognized that such behavior may make economic sense and create a real threat to competition when the firm operates in two different markets, one regulated and one unregulated. Increasingly that kind of situation will be common, given the changes occurring in these industries. Both regulatory law and antitrust law should take account of this danger. 
(2) Territorial division has been a hallmark of traditional regulation, reflecting the general view that a protected monopoly served the public interest better than a mixed system of regulated monopoly and competition at the fringe (especially "cream skimming"). On the other hand, territorial division, and other customer allocation systems, have long been held to be one of the clearest violations of the antitrust laws.

As we move from a largely regulated environment to a mixed competition/regulation environment, these two opposed positions will have to be reconciled. Where the territorial exclusivity scheme is clearly dictated by a regulatory program, it should be protected by the state action doctrine, but with the move to deregulate large parts of these markets, territorial schemes are clearly in jeopardy.

(3) Tying arrangements and other vertical distribution restraints are illegal under the antitrust laws, at least when the firm has market power in the relevant market and can thus coerce the consumer to purchase an unwanted product. In the utility industries, it has long been customary to "bundle" various services and products when offering them to the consumer. Such bundling has already been challenged in a number of situations, both under the antitrust laws and also as a matter of public utility regulatory policy. As deregulation proceeds and we depend more and more on competition to protect the public interest, marketing policies by dominant firms that bundle products and services become more and more vulnerable under the antitrust laws. This is especially true when a firm's remaining monopoly/regulated market is used to force the purchase of a product in the free market.

One of the first issues that must be faced, of course, is the definition of a product. Frequently in these businesses, it is not obvious whether one is dealing with one product or service rather than two or more products or services that have been bundled. 
(4) The Robinson-Patman Act prohibits some forms of price discrimination. The Act's application, however, is limited in various ways. For example, the Act only applies to the sale of commodities; it does not apply to the sale of services. A first question in the public utility context is whether one is dealing with a commodity or a service. The problem is posed, in part, by the traditional bundling of transportation or transmission service with product. While the transporting function of gas and water are clearly services, natural gas and water are themselves clearly products. Similarly, the equipment component and the content of messages in telecommunications are clearly products. The problem posed by electricity is much more difficult since the generation function supports transmission and distribution. With the unbundling of products and services in modern utilities, this issue takes on even more importance.

Also, to have a violation of the Robinson-Patman Act, one must have the sale of the same product to two or more purchasers at different prices. The identity of the product and its discrete price is critical and poses special issues for public utilities.

(5) Joint ventures pose special problems in all business settings under the antitrust laws. Often this method of organizing activity is particularly appropriate for achieving some important public benefit. However, since joint ventures frequently involve collaborative agreements among competitors, they may also be suspect under the antitrust laws. The public utility context demonstrates well the dilemma in public policy. There is a strong justification for highly integrated operations among the various participants in the industry. The telecommunications industry and the electric power industry are presently particularly marked by "network" characteristics.

Generally, such joint ventures can be justified under the antitrust laws, since the public benefit outweighs the anticompetitive danger, if care is taken not to include provisions or practices that are unnecessary to achieving the legitimate purpose of the joint venture and go no further than necessary to achieve the desirable purpose. 
Perhaps the most problematic areas involve access to membership in the joint venture or at least access to the benefits enjoyed by the members. In this and other contexts the "essential facilities" doctrine comes into consideration. That doctrine holds that one may be guilty of an antitrust violation if one uses, in a way that harms competition, market power over some factor essential to successfully engaging in the business involved. Here again, because of the mixed monopoly/competitive markets developing in the traditional public utilities, the possibility of antitrust problems with the essential facilities doctrine are particularly acute.

(6) With the vast changes in these industries, it perhaps is not surprising that a large number of mergers and acquisitions have been proposed or accomplished. A business realignment, based upon the new needs and opportunities, is inevitable in dynamic markets such as these. The antitrust concern is to assure that the mergers and acquisition do not create market structures that will harm competition or potential competition in these markets.

(7) Finally there are some defenses to antitrust charges that have special relevance in the public utility context. The "state action doctrine" reflects the accommodation, not only of antitrust concepts to the regulated markets involved, but also the accommodation of sometimes diverse federal and state legal policy objectives. The "filed rate doctrine" reflects the policy that a price set by a regulatory agency that has the jurisdiction to set that price, may not be attacked collaterally in an antitrust case. The "Noerr-Pennington doctrine" reflects the accommodation of collective political action, which may enjoy constitutional protection, with the normal antitrust concern with collective action that injures competition. Finally, standing and statute of limitation aspects of antitrust law may present special problems in the public utility context.

Each of these ideas and related issues are explored in this study. 


\section{TABLE OF CONTENTS}

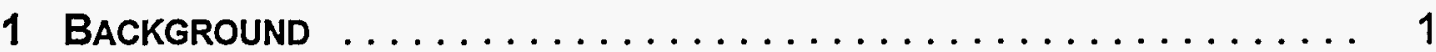

2 Modern DeVelopments in the Key Industries: Telecommunications, NATURAL GAS, AND Electric PoWER $\ldots \ldots \ldots \ldots \ldots \ldots \ldots, 5$

3 AN OVERVIEW OF THE ANTITRUST LAWS $\ldots \ldots \ldots \ldots \ldots \ldots \ldots \ldots$

Section One of the Sherman Act and Related Sections of the Clayton Act ............................... 13

Requirement of an Agreement .................. 13

Unreasonable Restraints of Trade ................ 14

The Per Se/Rule-of-Reason Distinction .............. 15

Horizontal Arrangements . . . . . . . . . . . . . . . . . 17

Vertical Arrangements . . . . . . . . . . . . . . . . . 23

Monopolization and Attempts to Monopolize: Section Two of the Sherman Act ................................. 27

Predatory Pricing ........................... 32

Horizontal Merger and Acquisition Activity ............. 34

Anticipating Demand Growth by Building Excess Capacity .... . . 35

Failure to Share New Research and Development ........... 36

Vertical Integration by Acquisition or Merger Foreclosing Markets

to Potential Competitors .......................... 36

Other Instances of Vertical Integration ............. 37

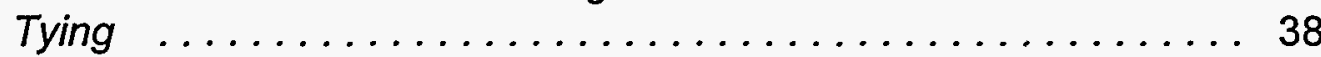

Boycotts or Refusals to Deal .................... 38

Price Discrimination: The Robinson-Patman Act ........... 39

Mergers and Acquisitions: Section Seven of the Clayton Act . . . . . 41 


\section{TABLE OF CONTENTS - Continued}

4 AN EXCURSION INTO THEORIES OF ANTITRUST VIOLATIONS

Cartel, Monopoly, and Oligopoly Theory as the Basis for Antitrust

Enforcement

The Leverage Theory .......................... 51

The Foreclosure Theory ......................... 57

New Strategic Behavior Theories ................. 58

5 Special Applications $\ldots \ldots \ldots \ldots \ldots \ldots \ldots \ldots \ldots \ldots \ldots \ldots$

Price Squeeze .......................... 61

Predatory Behavior in the Public Utility Context $\ldots \ldots \ldots \ldots \ldots \ldots 68$

Territorial Divisions ....................... 71

Restrictive Vertical Distribution Policies and Tying Arrangements . . . 73

Price Discrimination under the Robinson-Patman Act . . . . . . . 77

Joint Ventures . . . . . . . . . . . . . . . . . . . . . . . . 79

Access and the Essential Facilities Doctrine $\ldots \ldots \ldots \ldots \ldots \ldots 86$

Mergers and Acquisitions $\ldots \ldots \ldots \ldots \ldots \ldots \ldots \ldots \ldots \ldots$

6 Defenses of Special Relevance in the Public Utility Industries ... 99

The State Action Doctrine . . . . . . . . . . . . . . . . . . . . . 99

The Filed Rate Doctrine . . . . . . . . . . . . . . . . 100

Other Possible Defenses .......................... 104

Standing .............................. 104

Statute of Limitations . . . . . . . . . . . . . . . . . . . . . 105

Noerr-Pennington Doctrine ..................... 106

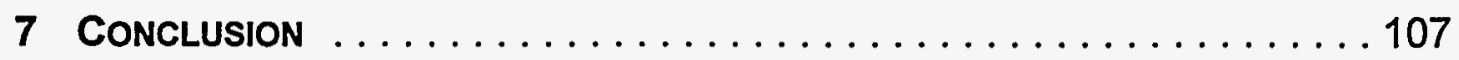




\section{ACKNOWLEDGMENTS}

The author expresses appreciation for the work of his research assistants, Greg Bauer, Alex Lattin, and Mark Owens, all law students at The Ohio State University, College of Law. I also appreciate the comments and suggestions of Robert E. Burns, Esq. and Dr. Douglas N. Jones of The National Regulatory Research Institute, as well as Dr. Christopher Klein of the Tennessee Public Service Commission. 



\section{FOREWORD}

As the current trend in public utility regulation toward more open and competitive markets becomes a reality, state and federal regulators may find that resultant "less than perfect" competition could itself be a major source of trouble. Utilities will maintain significant market power over distribution and transmission and over various services and market segments. This provides the utilities with opportunities to engage in exclusionary behavior, as well as to leverage monopoly power. State and federal utility regulators will want to familiarize themselves with antitrust principles and laws in the course of their consumer protection responsibilities. This NRRI report is the first in a series that deals with antitrust laws and principles in a variety of contexts that comprise the world of the public utility commissioners.

Douglas N. Jones

Director, NRRI

April 1996

Columbus, Ohio 


\section{CHAPTER 1}

\section{BACKGROUND}

Antitrust law was adopted and developed pursuant to a philosophy that, for most of the economy, the free market would best serve consumer interests and that the government should only be involved to ensure that competitive markets are preserved. To quote Justice Black, speaking for the Supreme Court in 1958, the antitrust laws were passed "on the premise that the unrestrained interaction of competitive forces will yield the best allocation of our economic resources, the lowest prices, the highest quality and the greatest material progress." ${ }^{11}$ However, it has also been generally recognized that some market situations are such that competition cannot be relied upon to protect consumer and societal interests. In these special situations, direct regulation has generally been considered a better solution to protect the public's economic interests.

Given that dichotomy in approach, one would expect that the antitrust laws, designed as they are to protect competitive markets so that the free market can work, would not be applied to regulated industries - those in which direct government regulation is substituted for the free market. For many years, that was the general impression of the legal accommodation. However, it has probably never been the law, at least on its face. The Supreme Court early on applied the antitrust laws to regulated industries ${ }^{2}$ and in several modern cases has explicitly discussed the issue and held that

1 Northern Pac. Ry. v. United States, 356 U.S. 1, 4 (1958).

2 See Northern Sec. Co. v. United States, 193 U.S. 197 (1904); United States v. Trans-Missouri Freight Ass'n, 166 U.S. 290 (1897). United States v. Terminal R.R. Ass'n of St. Louis, 224 U.S. 383 (1912). 
the antitrust laws do apply. ${ }^{3}$ The law, in general, provides no automatic exemption from the antitrust laws for regulated industries. As the Supreme Court has consistently said we have favored the free market, protected by the antitrust laws, as our basic economic framework, and only turn from that course where Congress has expressly chosen to exempt a practice or activity from antitrust coverage or where Congress or a state legislature ${ }^{4}$ has adopted a regulatory scheme that cannot be reconciled with the application of the relevant antitrust rule. ${ }^{5}$ In those rare situations, an exemption must either be implied or the legislative regulatory objective would be unattainable.

Such implied exemptions are strongly disfavored, however. ${ }^{6}$ There must be a finding that there is no way to reconcile the two legislative mandates before a court will recognize an implied exemption from the antitrust regime. ${ }^{7}$ Thus an uneasy

3 See, e.g., Otter Tail Power Co. v. United States, 410 U.S. 366, 372-77 (1973) ("Activities which come under the jurisdiction of a regulatory agency nevertheless may be subject to scrutiny under the antitrust laws." Id. at 372.); United States v. El Paso Natural Gas Co., 376 U.S. 651 (1964); Phonetele, Inc. v. American Tel. \& Tel. Co., 664 F.2d 716 (9th Cir. 1981), cert. denied., 459 U.S. 1145 (1983).

4 We shall return later to a discussion of the "state action" doctrine by which the "exemption" concept has been reconciled with the federalism concerns presented by our dual national-state sovereignty and resulting dual regulatory policies. See notes 277-81, infra, and accompanying text.

5 See generally, 1 Areeda \& Turner, Antitrust Law $\S \S 222-23$ (Little, Brown \& Co. 1978). In the electric power industry, this position was reinforced in the legislative debate preceding passage of the Public Utility Regulatory Policies Act of 1978 (PURPA):

... it is not intended that the courts defer actions arising under the antitrust laws pending a resolution of such matters by [the Federal Energy Regulatory Commission, (FERC)]. . . .Courts have jurisdiction to proceed with antitrust cases without deferring to the Commission for the exercise of primary jurisdiction.

House Conference Report No. 95-1750, 95th Cong., 2d Sess. 63, 1978 U.S. Code Cong. and Ad. News 7802.

Moreover, Section 712(e)(2) of the Energy Policy Act of 1992, 16 U.S.C. $\S 824(k)$, amending $\S 212$ of the Federal Power Act, provides that "Sections 210, 211, 213, 214, and this section [of the Federal Power Act], shall not be construed to modify, impair, or supersede the antitrust laws"....

6 "'Repeals of the antitrust laws by implication from regulatory statute are strongly disfavored, and have only been found in cases of plain repugnancy between the antitrust and regulatory provisions'.... Activities which come under the jurisdiction of a regulatory agency nevertheless may be subject to scrutiny under the antitrust laws." Otter Tail Power Co. v. United States, 410 U.S. 366, 372, 375 (1973) (quoting from United States v. Philadelphia Nat'l Bank, 374 U.S. 321, 350-51 (1963)).

7 See, e.g., Pan American World Airways v. United States, 371 U.S. 296, 304-5 (1963). 
accommodation of the antitrust approach, preserving free market activity, and direct government economic regulation has developed over the years. Where competition is possible without sacrificing the public interest goals of direct regulation, the antitrust laws are applied and a substantial jurisprudence in each of the regulated industries has emerged. ${ }^{8}$

8 In addition to the many other sources cited to specific matters to be discussed herein, see Green \& Bouknight, "Electric Utility Antitrust Issues in an Era of Bulk Power Market Competition," 8 Nat. Res. \& Env. 20 (Winter 1994); LaRue, "Antitrust and the Natural Gas Industry," 11 Energy L.J. 37 (1990); Gagax \& Nowotny, "Competition and the Electric Utility Industry: An Evaluation," 10 Yale J. on Reg. 63 (1993); Werner, "Something's Gotta Give: Antitrust Consequences of Telephone Companies' Entry into Cable Television," 43 Fed. Comm. L.J. 215 (1991). 



\section{CHAPTER 2}

\section{MODERN DEVELOPMENTS IN THE KEY INDUSTRIES: TELECOMMUNICATIONS, ${ }^{9}$ NATURAL GAS, AND ELECTRIC POWER}

Starting in the late 1970s and early 1980s the key public utility industries, with which this study is concerned, started to undergo significant technological and economic change. ${ }^{10}$ One aspect of that change has been to open broad new avenues for the possible role of competition. In all three major industries we have witnessed in recent years the evolution of substantial competition in significant parts of each industry.

Simultaneously, economic thinking about the efficacy of economic regulation has been changing, first by legal and economic theorists and then by the regulatory agencies and the courts. ${ }^{11}$ Thus, coincident with the development of more feasible competitive markets in these industries, the questions about effectiveness of regulation has spawned a significant move toward deregulation and reliance upon free competitive market forces to protect the consumer and the public interest. These developments in turn call into play a potentially much greater role for the antitrust laws - to ensure the integrity of those free market forces. These new contexts require a rethinking of the way that the antitrust concepts should be applied and adapted to these newly emerging, partially competitive and partially regulated, industries.

9 The key industries for purposes of this study are gas, electricity, and telecommunications. The latter shall include the entire modern information transmission industry, as it now clearly includes more than the traditional telecommunications segment. Specifically, as used here, it will include at least telephone, data transmission, and picture transmission, including the cable industry.

${ }^{10}$ These changes are traced out in NRRI, Status of the Four Utility Sectors: Background WriteUps (Prepared for the NRRI/NARUC Summit Conference "PUCs at 2000," Denver, Colorado, April 4-5, 1995); Phillips, "The Regulation of Public Utilities" (Pub. Util. Rpts. 1993).

11 See Phillips, supra note 10, at 11-27; Pierce, Economic Regulation (Anderson 1994); Pierce, "Reconsidering the Roles of Regulation and Competition in the Natural Gas Industry," 97 Harv. L. Rev. 345 (1983); Pierce, "A Proposal to Deregulate the Market for Bulk Power," 72 Va. L. Rev. 1183 (1986). 
An array of only partially related circumstances occurred over a relatively short period of time that transformed each of these industries. In telecommunications, technological development, related to the fast changing world of electronics, has been perhaps the most important factor. ${ }^{12}$ However, the antitrust case that resulted in the vertical disintegration of American Telephone and Telegraph Company (AT\&T) was also a major factor in leading to the technological advances to transform the industry. ${ }^{13}$

Until the 1980s this industry was dominated by AT\&T's control over long-distance and local service in most areas of the country, as well as equipment production and system engineering. Now, only a few years later, most equipment and many services, including all long-distance service, are offered competitively. We also have become somewhat less dependent upon the local wire system to connect users with the network necessary to have universal or near universal communications. The development of the microwave and satellite transformed long-distance communication. The development of cellular phones and cable television systems has the potential, already apparent in some locations, to transform the local market. ${ }^{14}$

Moreover, until recently, legal restrictions prevented AT\&T from entering into many related information program-creation and transmission businesses, such as cable

12 The evolution of this industry is traced out in Phillips, supra note 10 , at Chapter 15 . See also Davis, Kruse, Pollard \& Reed, Competition and Interconnection: The Case of Personal Communications Services (Mono. \#94-11 NRRI 1994); Brent, Kruse \& Landsbergen, The Impact of Alternative Technologies on Universal Service and Competition in the Local Loop (Mono. \#92-16 NRRI 1992); Borrows \& Graniere, An Open Network Architecture Primer for State Regulators (Mono. \#91-20 NRRI 1991); Lawton, Telecommunications Modernization: Issues and Approaches for Regulators (Mono. \#87-14 NRRI 1987).

${ }^{13}$ United States v. American Tel. \& Tel. Co., 524 F. Supp. 1336 (D.D.C. 1981) and 552 F. Supp.131 (D.D.C. 1982), aff'd mem. sub. nom., Maryland v. United States, 460 U.S. 1001 (1983). The case is discussed in detail by two of the architects of the government's case in Noll \& Woen, The Anticompetitive Uses of Regulation: United States v. AT\&T in The Antitrust Revolution, at 290 (Kwoka \& White, eds., Scott, Foresman 1989). See also MCl Communications Corp. v. American Tel. \& Tel. Co., 708 F.2d 1081 (7th Cir.), cert. denied, 464 U.S. 891 (1983).

${ }^{14}$ See the Order of the Ohio PUC permitting competition in the local telephone market. Re Time Warner Communications of Ohio L.P., 163 P.U.R.4th 326 (PUC of Ohio, Oct. 9, 1995). The antecedents of that decision are discussed in Darr, "Deregulation of Telephone Services in Ohio," 24 Akron L. Rev. 229 (1990). See also, e.g., Dugger, "TeleKansas and the Future of Alternative Telecommunications Regulation in Kansas," 43 U. Kan. L. Rev. 687 (1995); Siembab, "Opening the IntraLATA Market in California: Tolls Drop but Casualties Rise," 28 Loy. L.A. L. Rev. 1453 (1995); In re Rochester Telephone Corp., Docket Nos. 94071/93C0033, 93C01103, reported in PUR Util. Wkly., Oct. 14, 1994. 
television service. These walls are now collapsing ${ }_{1}^{15}$ resulting in the possible coalescence of much of the entertainment, information management and transmission, and telecommunication industries. ${ }^{16}$

Turning to the natural gas industry, ${ }^{17}$ political events affecting the world oil market in the 1970s, coupled with the failure of field price regulation, led to shortages of natural gas that affected all aspects of life and the economy in the United States. The cost of natural gas shot up, shortages necessitated the curtailment of services, and predictions were common that we were about to run out of natural gas.

At the same time, environmental concerns led to very significant efforts to decrease the use of energy. With the abandonment of the ill-starred policy of field price regulation, leading to higher prices and increased rewards for discovery of new gas substantial new reserves were discovered and available to the market. Meanwhile the market had, relatively speaking, shrunk, creating a large surplus of natural gas, available in the market at substantially reduced prices from those prevailing during the shortage period.

${ }^{15}$ The Telecommunications Act of 1996, Pub. Law 104-104, signed into law on Feb. 8, 1996, essentially eliminates any restrictions on the lines of business that a telecommunications firm may enter. Even prior to that the FCC had significantly reduced the constraints. See FCC Final Rule Concerning Network Financial Interest and Syndication Rules, 60 Fed. Reg. 48,907 (1995) (repealing financial interest and syndication ["fin/syn"] rules in their entirety). See also Schurz Communications, Inc. v. FCC, 982 F.2d 1043 (7th Cir. 1992).

The Communications Policy Act of 1984, 47 U.S.C. $\S 533(b)$, had prohibited firms from engaging in both the television cable business and the telephone business. That Act had been declared unconstitutional even before passage of the 1996 Act made the issue moot. See, Chesapeake \& Potomac Tele. Co. v. FCC, 42 F.3d 181 (4th Cir. 1994), judgment vacated, __ U.S. _ 1996 WL 79701 (1996); U S West, Inc. v. United States, 48 F.3d 1092 (9th Cir. 1994), cert. granted and judgment vacated, U.S. 1996 WL 89112 (1996); cf., National Cable Television Assoc. v. FCC, 33 F.3d 66 (1994).

${ }^{16}$ Indeed these industries have experienced a rash of mergers and acquisitions of late that demonstrate this coalescence and from most reports, the restructuring of these industries is just beginning. See, e.g., "Telecom Vote Signals Competitive Free-For-All: Likely Mergers Herald an Era of Megacarriers," Wall St. J., Feb. 2, 1996, at B1; Phillip L. Zweig et al., "The Case Against Mergers," Bus. Wk., Oct. 30, 1995, at 122; Rita Koselka (interviewing Michael J. Wolf), "Mergermania in Medialand," Forbes, Oct. 23, 1995, at 252.

${ }^{17}$ See, e.g., Phillips, supra note 10, at Chapter 14; Pierce, "Reconsidering the Roles of Regulation and Competition in the Natural Gas Industry," 97 Harv. L. Rev. 345 (1983); Pierce, "Reconstituting the Natural Gas Industry From Wellhead to Burnertip," 9 Energy L.J. 1 (1988); Duann, The FERC Restructuring Rule: Implications for Local Distribution Companies and State Public Utility Commissions (Mono. \#93-12 NRRI 1993). 
In this industry, too, there was technological progress with regard to discovery, exploitation of new gas fields, and storage. However, the primary force for change was the economics of the market place. Large industrial users, who had other options, began to press very hard for cheaper prices. After trying some less drastic approaches, the Federal Energy Regulatory Commission (FERC) ultimately created a completely competitive wholesale supply market by forcing the interstate pipelines to move from a buy-sell "merchant" function to a contract-carrier/common-carrier transportation function. ${ }^{18}$ Moreover, in much of the country there developed new pipeline capacity that provided competition even for the transportation function. Finally, competition to serve the local retail market in some states is developing as a result of changes in state regulation, and a whole new industry of gas marketers/brokers is developing to replace the merchant function formerly provided by the pipelines. ${ }^{19}$

The electric power industry also was hit by the energy crisis of the early 1970 s, but environmental concerns and safety issues (related to nuclear power) perhaps are playing an even greater role in its transformation. ${ }^{20}$ Technology is permitting a greater and greater degree of integrated system management, while at the same time the ability to transmit power efficiently over longer and longer distances has been

${ }^{18}$ See FERC, Pipeline Services Obligations and Revisions to Regulations Governing Selfimplementing Transportation; and Regulation of Natural Gas Pipelines After Partial Wellhead Decontrol, 18 C.F.R. § 284 (1992).

${ }^{19}$ Duann, Restructuring Local Distribution Services: Possibilities and Limitations (NRRI Mono. \#94-13 1994).

${ }^{20}$ For a description of the changes in the electric power industry, see, e.g., Phillips, supra note 10, at Chapter 13; Pierce, "A Proposal to Deregulate the Market for Bulk Power," 72 Va. L. Rev. 1183 (1986); Black \& Pierce, "The Choice between Markets and Central Planning in Regulating the U.S. Electricity Industry," 93 Colum. L. Rev. 1339 (1993); Pierce, "Using the Gas Industry as a Guide to Reconstituting the Electricity Industry," 13 J. Res. Law \& Econ. 7 (1991). The following NRRI monographs are also helpful in tracing these developments: Costello, Burns \& Hegazy, Overview of Issues Related to the Retail Wheeling of Electricity (NRRI Mono. \#94-09 1994); Rose, Burns, \& Eifert, Implementing a Competitive Bidding Program for Electric Power Supply (NRRI Mono. \#90-15 1990); Kelly, Hobbs, \& Eifert, Electricity Transmission Access and Pricing Policies: Issues and a Game-Theoretic Evaluation (NRRI Mono \#90-10 1990); Duann, Burns, Jones \& Eifert, Competitive Bidding for Electric Generating Capacity: Application and Implementation (NRRI Mono. \#88-12 1988); Kelly, Non-Technical Impediments to Power Transfers (NRRI Mono. \#87-08 1987); Kelly, Henderson, Nagler \& Eifert, Some Economic Principles for Pricing Wheeled Power (NRRI Mono. \#87-07 1987); Lindsay \& Pfeffer, Deregulation of the Electric Power Industry: Perspective of State Regulation (NRRI Mono. \#83-06 1983). 
developing. In addition, the cost comparison between very large, expensive centralstation generating units and various smaller generation options has changed - to a large extent a result of new health, safety, and environmental regulations that have added enormous costs to the construction of large generating facilities of all kinds.

In addition, starting in the early 1970 s real increases in the price for electric power led to a significant relative drop in demand for electric power. It became clear over a fairly short period of time that demand for electricity was much more price elastic than had previously been thought. Meanwhile, Congress acted. In 1978 it passed legislation aimed at encouraging conservation and decreases in demand at the same time it encouraged the development of alternative generation sources that were less threatening to environmental concerns and safety. ${ }^{21}$

Suddenly, electric power companies found themselves with substantial excess capacity, either in existence or under construction. Many of these construction projects were terminated, but many were completed, although there was no ready market for the power produced - at least, not at the price necessary to pay their costs under traditional ratemaking formulae. ${ }^{22}$

In addition, the effective deregulation of the field price of natural gas helped to cause a change in the fundamental calculations of the cost of new capacity. Gas-fired generation suddenly became very attractive and with the technical improvements in small gas-fired generation units, the prior advantages of large-scale generation units ceased to exist. This not only altered the cost calculations for generating companies but provided a competitive option for customers that used enough power to justify their own installation of these new, small units.

${ }^{21}$ Public Utility Regulatory Policies Act of 1978,46 U.S.C. $\S \S 2601-2645$.

${ }^{22}$ See, e.g. Burns, Poling, Whinihan \& Kelly, The Prudent Investment Test in the 1980s (NRRI Mono. \#84-16 1984); Canaday, Construction Cost Overruns in Electric Utilities: Some Trends and Implications (NRRI Mono. \#80-08 1980); Pierce, "The Regulatory Treatment of Mistakes in Retrospect: Canceled Plants and Excess Capacity," 132 U. Pa. L. Rev. 497 (1984). Cases dealing with some of the problems posed by these projects include Mississippi Power \& Light Co. v. Mississippi ex rel. Moore, 487 U.S. 354 (1988); Kansas Gas \& Elec. Co. v. State Corp. Comm'n of Kansas, 239 Kan. 483, 720 P.2d 1063 (1986). 
With Congressional and FERC encouragement these forces have produced a significant market, or at least potential market, for wholesale electric power. Congress encouraged the development of a competitive wholesale market with the passage of the Energy Policy Act of 1992 (EPAct), which gave the FERC power for the first time to order regulated firms to transmit wholesale power for other companies over their transmission facilities. ${ }^{23}$ The FERC has followed that up with a proposed rule. This rule would require open access for wholesale transactions at the transmission level much like what has happened in the gas industry, although it must be understood that there are much greater technical problems to such open access to transmission in the electric power industry. ${ }^{24}$ In addition, some states are proposing various forms of competition at the retail level as well. ${ }^{25}$

${ }^{23}$ This is referred to as "wheeling power." See Energy Policy Act of 1992, Title VII, $\S 7721$ and 722, Pub. Law 102-486, 106 Stat. 2776 (1992), 16 U.S.C. § 824j. See generally, Watkiss \& Smith, "The Energy Policy Act of 1992 - A Watershed for Competition in the Wholesale Power Market," 10 Yale J. on Reg. 447 (1993).

${ }^{24}$ See FERC Notice of Proposed Rulemaking, 60 Fed. Reg. 17,662 (1995) (to be codified at 18 C.F.R. § 35) (proposed April 7, 1995); "FERC Seeks More Fully Competitive Wholesale Electric Power Market," Util. L. Rep. (CCH) No. 1108 (April 13, 1995). The Commission has ordered a number of public hearings on the many technical problems that must be confronted. Se Util. L. Rep. (CCH) No. 1129 (Sept. 7, 1995).

${ }^{25}$ See, e.g., Order Instituting Rulemaking and Order Instituting Investigation, I.94-04-032 (Cal. PUC April 20, 1994) \& D.95-05-045 (Cal. PUC May 24, 1995). Henney, "The Power Exchange: California Goes Competitive?" Pub. Util. Fort., at 22 (March 1, 1996). An article by the Chair of the Michigan Public Service Commission describes developments in Michigan and California as of mid-1994. Strand, "Retail Wheeling: A View from Michigan," Pub. Util. Fort., at 29 (Sept. 15, 1994). For a survey of state legislative action, see Legislative Energy Advisory Program, Q. Legis. Letter (Winter 1996). See also, Arny and James, "New Attitudes Toward Transmission - Wisconsin Style," Pub. Util. Fort., at 12 (Sept. 15, 1991). 


\section{CHAPTER 3}

\section{AN OVERVIEW OF THE ANTITRUST LAWS ${ }^{26}$}

The statutory sections of the antitrust laws most relevant for the purposes of this study are the Sherman Act Sections One and Two, ${ }^{27}$ the Clayton Act Section Two (customarily referred to as the Robinson-Patman Act), ${ }^{28}$ Section Three, ${ }^{29}$ and Section

\footnotetext{
${ }^{26}$ Two excellent one-volume treatises on antitrust law are Hovenkamp, Federal Antitrust Policy (West 1994) and Ross, Principles of Antitrust Law (Foundation Press 1993). A much more extensive treatment can be found in the multi-volume treatise Areeda \& Turner, Antitrust Law (Little, Brown \& Co. 1978).

${ }^{27}$ Section 1 of the Sherman Act, 15 U.S.C. $\$ 1$, provides:

Every contract, combination in the form of trust or otherwise, or conspiracy, in restraint of trade or commerce among the several States, or with foreign nations, is hereby declared to be illegal. ...
}

Section 2 of the Sherman Act, 15 U.S.C. § 2, provides:

Every person who shall monopolize, or attempt to monopolize, or combine or conspire with any other person or persons, to monopolize any part of the trade or commerce among the several states, or with foreign nations, shall be deemed guilty of a felony. ...

${ }^{28}$ Section 2 of the Clayton Act, commonly referred to as the Robinson-Patman Act, 15 U.S.C. $\S 13(a)$, provides, in part:

(a) Price; selection of customers. It shall be unlawful for any person engaged in commerce, in the course of such commerce, either directly or indirectly, to discriminate in price between different purchasers of commodities of like grade and quality, where either or any of the purchases involved in such discrimination are in commerce, where such commodities are sold for use. . . within the United States. . and where the effect of such discrimination may be substantially to lessen competition or tend to create a monopoly in any line of commerce, or to injure, destroy, or prevent competition with any person who either grants or knowingly receives the benefit of such discrimination, or with customers of either of them. ...

${ }^{29}$ Section 3 of the Clayton Act, 15 U.S.C. $§ 14$, provides:

Sale. . on agreement not to use goods of competitor. It shall be unlawful for any person engaged in commerce, in the course of such commerce, to lease or make a sale or contract for sale of goods, wares, merchandise, machinery, supplies or other commodities, whether patented or unpatented, for use, consumption or resale within the United States. . ., or fix a price charged therefore, or discount from, or rebate upon, such price, on the condition, agreement or understanding that the lessee or purchaser thereof shall not use or deal in the goods. .., where the effect of such lease, sale, or contract for sale or such condition, agreement or understanding may be to substantially lessen competition or tend to create a monopoly in any line of commerce.

Note that Section 1 of the Sherman Act covers the same kind of arrangements except that the Sherman Act requires an agreement and the Clayton Act only applies to products. 
Seven. ${ }^{30}$ These laws in general are enforceable by the Antitrust Division of the United States Department of Justice (Justice Department), the Federal Trade Commission (FTC), ${ }^{31}$ by state attorneys general suing as parens patriae for their citizens, ${ }^{32}$ and/or by any private party who is injured by the alleged violation. ${ }^{33}$ The suit may be in the form of a class action. ${ }^{34}$ If damages are awarded in a private-party action, they are trebled, which can make a violation that damages others a very expensive proposition. ${ }^{35}$ The

${ }^{30}$ Section 7 of the Clayton Act, 15 U.S.C. $§ 18$, provides:

Acquisition by one corporation of stock of another. No person engaged in commerce or in any activity affecting commerce shall acquire, directly or indirectly, the whole or any part of the stock or other share capital and no person subject to the jurisdiction of the Federal Trade Commission shall acquire the whole or any part of the assets of another person engaged also in commerce or in any activity affecting commerce, where in any line of commerce or in any activity affecting commerce in any section of the country, the effect of such acquisition may be substantially to lessen competition, or to tend to create a monopoly.

... Nothing contained in this section shall apply to transactions duly consummated pursuant to authority given by the Secretary of Transportation, Federal Communications Commission, Federal Power Commission, Interstate Commerce Commission, the Securities and Exchange Commission in the exercise of its jurisdiction under Section 10 of the Public Utility Holding Company Act of 1935 [15 U.S.C. § 79j], the United States Maritime Commission, or the Secretary of Agriculture under any statutory provision vesting such power in such Commission or Secretary.

${ }^{31}$ The Federal Trade Commission Act $\S 5(2)(2), 15$ U.S.C. $\S 45$, provides, in pertinent part: The commission is empowered and directed to prevent persons, partnerships, or corporations. . . from using unfair methods of competition in or affecting commerce and unfair or deceptive acts or practices in or affecting commerce.

The Federal Trade Commission does not have direct enforcement power but the "unfair methods of competition" language of Section 5 has been interpreted as including all activities that would violate the other antitrust acts, thus giving the FTC enforcement power over the whole range of antitrust laws unless otherwise provided. See, e.g., FTC v. Cement Institute, 333 U.S. 683, 708-09 (1948).

${ }^{32}$ Section $4 \mathrm{C}(\mathrm{a})(1)$ of the Clayton Act, 15 U.S.C. $\S 15 \mathrm{C}$, provides this power.

${ }^{33}$ Section 4 of the Clayton Act, 15 U.S.C. $\$ 15$, provides, in pertinent part: "[A]ny person who shall be injured in his business or property by reason of anything forbidden in the antitrust laws may sue therefore in any district court of the United States. . ."

${ }^{34}$ Rule 23 of the Federal Rules of Civil Procedure.

${ }^{35}$ Section 4 of the Clayton Act, 15 U.S.C. $\S 15$, provides, in pertinent part: "[A]ny person who shall be injured. . . shall recover threefold the damages by him sustained, and the cost of the suit, including a reasonable attorney's fee. .." 
Justice Department may sue for civil remedies or enforce the criminal provisions of the Sherman Act. ${ }^{36}$

\section{Section One of the Sherman Act and Related Sections of the Clayton Act}

\section{Requirement of an Agreement}

Section One makes illegal "Every contract, combination. . .or conspiracy in restraint of trade." Therefore to prove a Section One offense, one must prove some form of collective action. A single firm's action cannot violate Section One. Joint action by two or more entities is essential. Moreover, after many years in which the courts held otherwise, the Supreme Court has now clearly held that the requisite contract, combination, or conspiracy must be between separate business entities. It is no longer sufficient to prove only an "agreement" between a parent business entity and its whollyowned or controlled subsidiary or between subsidiaries of the same parent organization. ${ }^{37}$ Of course, the agreement can be proven by circumstantial evidence or inferred from the situation. It need not be set out in writing or other explicit terms. A tacit agreement is enough, although after some uncertainty, it now appears that mere parallel behavior, even if interdependent, is not enough. ${ }^{38}$

${ }^{36}$ See 15 U.S.C. $§ 16$.

${ }^{37}$ See Copperweld Corp. v. Independence Tube Corp., 467 U.S. 752, 777 (1984) ("We hold that Copperweld and its wholly owned subsidiary Regal are incapable of conspiring with each other for purposes of Section 1 of the Sherman Act. To the extent that prior decisions of this Court are to the contrary, they are disapproved and overruled.").

${ }^{38}$ Compare Interstate Circuit, Inc. v. United States, 306 U.S. 208 (1939) and Triangle Conduit \& Cable Co. v. FTC, 168 F.2d 175 (7th Cir. 1948), affd by an equally divided Court, sub nom., Clayton Mark \& Co. v. FTC, 336 U.S. 956 (1949), with Theatre Enterprises v. Paramount Film Distributing Corp., 346 U.S. 537 (1954) ("[T]his Court has never held that proof of parallel business behavior conclusively establishes agreement or, phrased differently, that such behavior itself constitutes a Sherman Act offense."); Boise Cascade Corp. v. FTC, 637 F.2d 573 (9th Cir. 1980); E.I. du Pont de Nemours \& Co. v. FTC, 729 F.2d 128 (2d Cir. 1984). See generally, Turner, "The Definition of Agreement Under the Sherman Act: Conscious Parallelism and Refusals to Deal," 75 Harv. L. Rev. 655 (1962). 


\section{Unreasonable Restraints of Trade}

Once the agreement requirement is satisfied, one turns to the question of whether the agreement is in restraint of trade. The first cases brought under this section read the language literally ${ }^{39}$ but very early the Supreme Court recognized that such a reading would make illegal almost any business arrangement. As a result, the courts modified the language to cover only "unreasonable" restraints of trade. ${ }^{40}$ Much of the subsequent case law has dealt with the attempt to define unreasonable.

Today, the term has been read to mean any interference with the free market process for determining price, quality, quantity of output, or other important term of a transaction. ${ }^{41}$ The Supreme Court has now articulated classic economic price theory to be the touchstone, the standard, for all antitrust analysis. ${ }^{42}$

During an earlier time, "unreasonable restraint of trade" was read more broadly to include political-social objectives other than those dictated by a competitive market as defined in classical economic terms. Particularly, there was a concern for the plight of the small, local business person confronted by giants of trade or industry. The concern was for a preservation of the Jeffersonian model of a political-social world built

${ }^{39}$ See, e.g., United States v. Trans-Missouri Freight Ass'n, 166 U.S. 290, 328 (1897) ("When, therefore, the body of an act pronounces as illegal every contract in restraint of trade or commerce among the several states, etc., the plain and ordinary meaning of such language is not limited to that kind of control alone which is in unreasonable restraint of trade, but all contracts are included in such language, and no exception or limitation can be added without placing in the act that which has been omitted by Congress.").

${ }^{40}$ See Board of Trade of Chicago v. United States, 246 U.S. 231, 238 (1918) ("But the legality of an agreement or regulation cannot be determined by so simple a test, as whether it restrains competition. Every agreement concerning trade, every regulation restrains. To bind, to restrain, is of their very essence. The true test of legality is whether the restraint imposed is such as merely regulates and perhaps thereby promotes competition or whether it is such as may suppress or even destroy competition."); Standard Oil Co. v. United States, 221 U.S. 1 (1911).

${ }^{41}$ See, e.g., Nat'I Soc'y of Professional Eng'rs v. United States, 435 U.S. 679 (1978); Continental T.V., Inc. v. GTE Sylvania, Inc., 433 U.S. 36 (1977).

${ }^{42}$ See, e.g., Brooke Group Ltd. v. Brown \& Williamson Tobacco Corp., 509 U.S. 209 (1993); Matsushita Elec. Indus. Co. v. Zenith Radio Corp., 475 U.S. 574 (1986). 
upon individual initiative and entrepreneurial spirit. This approach was taken to the point at times of subsidizing inefficient market situations in the interest of protecting small business operations. ${ }^{43}$ Whether such goals were ever intended to be part of antitrust law jurisprudence, they have been largely repudiated in the Supreme Court case law since the mid-1970s, except as those social goals are served by the classical price theory approach. ${ }^{44}$ Today, the end sought is the creation or protection of the free market. One looks at the potential for harm to the competitive process and assesses that against any procompetitive business justification in deciding the reasonableness issue..$^{45}$

\section{The Per Se/Rule-of-Reason Distinction}

The Supreme Court has also declared some practices and conduct to be illegal per se; that is, so likely to be pernicious and so unlikely to convey any consumer-

${ }^{43}$ See Brown Shoe Co. v. United States, 370 U.S. 294 (1962); United States v. Von's Grocery Co., 384 U.S. 270 (1966); United States v. Aluminum Co. of Am., 148 F.2d 416 (2d Cir., sitting in lieu of the Supreme Court, 1945); Topps Chewing Gum, Inc. v. Major League Baseball Players Ass'n, $641 \mathrm{~F}$. Supp. 1179 (S.D.N.Y. 1986). See also 1 Areeda \& Turner, supra note 26, at fIT 109-12; Bork, Bowman, Blake \& Jones, "The Goals of Antitrust: A Dialogue on Policy," 65 Colum. L. Rev. 363 (1965).

${ }^{44}$ See Brooke Group Ltd. v. Brown \& Williamson Tobacco Corp., 509 U.S. 209 (1993); Continental T.V., Inc. v. GTE Sylvania, Inc., 433 U.S. 36 (1977) (see especially the Court's footnote 21). The Court has also articulated this same basic approach in applying Section 2 of the Sherman Act. In Spectrum Sports, Inc. v. McQuillan, 506 U.S. 447, 458 (1993), an attempt to monopolize the case, the Court said:

The purpose of the Act is not to protect businesses from the working of the market; it is to protect the public from the failure of the market. The law directs itself not against conduct which is competitive, even severely so, but against conduct which unfairly tends to destroy competition itself.

It does so not out of solicitude for private concerns but out of concern for the public interest.

See also 1 Areeda \& Turner, supra note 26, at ITा 103-13.

${ }^{45}$ See, e.g., National Collegiate Athletic Ass'n v. Board of Regents of Univ. of Okla., 468 U.S. 85 (1984); Continental T.V., Inc. v. GTE Sylvania, Inc., 433 U.S. 36 (1977); Broadcast Music, Inc. v. Columbia Broadcasting Sys., Inc., 441 U.S. 1, 19-20 (1979):

"[O]ur inquiry must focus on whether the effect and, here because it tends to show effect, the purpose of the practice are to threaten the proper operation of our predominately free-market economy - that is whether the practice facially appears to be one that would always or almost always tend to restrict competition and decrease output, and in what proportion to the market, or instead one designed to 'increase economic efficiency and render markets more, rather than less, competitive."' (Citations omitted.) 
welfare benefits that one can presume the conduct to be unreasonable. ${ }^{46}$ In such cases, the court infers the anticompetitive consequences of the conduct without the necessity of actual proof. The type of conduct that qualifies for per se treatment has shifted somewhat over the years ${ }^{47}$ and the Court has, at times, carved out exceptions for certain groups because of unique considerations. ${ }^{48}$

As a practical matter, proof of conduct categorized as presenting a per se offense raises at least a presumption of guilt and is enough to get to a jury on the issue, if not a summary judgment. The burden of proof is effectively shifted to the defense to prove some procompetition justification or defense.

If the per se rule does not apply, then the courts will use what is called a "rule of reason" analysis. ${ }^{49}$ The courts have not been particularly clear on what this analysis means, but at least in rule of reason cases the courts are willing to listen to business defenses for the conduct and weigh the possible anticompetitive consequences against

${ }^{46}$ United States v. Socony-Vacuum Oil Co., 310 U.S. 150, 218 (1940) ("Thus for over forty years this court has consistently and without deviation adhered to the principle that price-fixing agreements are unlawful per se under the Sherman Act and that no showing of so-called competitive abuses or evils which those agreements were designed to eliminate or alleviate may be interposed as a defense."); Northern Pac. Ry. v. United States, 356 U.S. 1 (1958) (tying arrangements); Catalano, Inc. v. Target Sales, Inc., 446 U.S. 643 (1980) (credit terms); Palmer v. BRG of Ga., Inc., 498 U.S. 46 (1990) (horizontal territorial arrangements); Arizona v. Maricopa County Medical Soc'y, 457 U.S. 332 (1982) (maximum price fixing); Continental T.V., Inc. v. GTE Sylvania, Inc., 433 U.S. 36 (1977) (dictum, vertical price fixing).

${ }^{47}$ For example, note the Court's contrasting treatment of vertically imposed marketing restrictions in White Motor Co. v. United States, 372 U.S. 253 (1963) (no per se rule applicable); United States v. Arnold, Schwinn \& Co., 388 U.S. 365 (1967) (per se rule applicable); Continental T.V., Inc. v. GTE Sylvania, Inc., 433 U.S. 36 (1977) (overruling Schwinn on applicability of per se rule). See also Jefferson Parish Hosp. Dist. No. 2 v. Hyde, 466 U.S. 2 (1984) (narrowing the application of the per se rule in tying cases).

${ }^{48}$ E.G. Goldfarb v. Virginia State Bar, 421 U.S. 773 (1975) (legal profession); National Collegiate Athletic Ass'n v. Board of Regents of Univ. of Okla., 468 U.S. 85 (1984) (league sports); National Soc'y of Professional Eng'rs v. United States, 435 U.S. 679 (1978) (engineering profession).

49 The classic formulation is in Board of Trade of Chicago v. United States, 246 U.S. 231 (1918), in which Justice Brandeis lists several factors, some even inconsistent, which should be considered. See also Continental T.V., Inc. v. GTE Sylvania, Inc., 433 U.S. 36 (1977); National Collegiate Athletic Ass'n v. Board of Regents of Univ. of Okla., 468 U.S. 85 (1984); Broadcast Music, Inc. v. Columbia Broadcasting Sys., Inc., 441 U.S. 1 (1979). See generally, Ross, supra note 26, at 123-27, 134-43. 
the procompetition, consumer-welfare justification..$^{50}$ However, the Supreme Court has made very clear that the justification must be some competition creating or promoting defense; it is not acceptable to argue that the competitive market fails to protect the consumer welfare and therefore the challenged collective action should be substituted for the competitive market. ${ }^{51}$ The Court, in recent years, has consistently held that only Congress can make the decision that the public interest demands exemption of the conduct from antitrust coverage. ${ }^{52}$

\section{Horizontal Arrangements}

The instances in which the courts have imposed the most severe per se rules are those involving agreements among competitors to fix prices or restrain output. ${ }^{53}$ The latter is illustrated by agreements among competitors to allocate territories or to impose customer limitation or output quotas upon themselves. Illegal price fixing includes price floors, price ceilings, any agreement on a pricing formula, or otherwise tampering with anything that directly affects the financial terms of a deal between seller

${ }^{50}$ See, e.g., Broadcast Music, Inc. v. Columbia Broadcasting Sys., Inc., 441 U.S. 1 (1979); Rothery Storage \& Van Co. v. Atlas Van Lines, Inc., 792 F.2d 210 (D.C. Cir. 1986); Vogel v. American Soc'y of Appraisers, 744 F.2d 598 (7th Cir. 1984); Mozart Co. v. Mercedes-Benz of N. Am., Inc., 833 F.2d 1342 (9th Cir. 1987), cert. denied, 488 U.S. 870 (1988).

${ }^{51}$ See FTC v. Indiana Fed'n of Dentists, 476 U.S. 447 (1986); Arizona v. Maricopa County Medical Soc'y, 457 U.S. 332 (1982); Nat'l Soc'y of Professional Eng'rs v. United States, 435 U.S. 679 (1978).

52 The Court has also clearly held that state legislatures can adopt alternative regulatory schemes that may substitute for the application of the antitrust laws. This rule is referred to as the "state action doctrine" and will be discussed later in the text that accompanies footnotes, 277-281.

${ }^{53}$ See, e.g., United States v. Socony-Vacuum Oil Co., 310 U.S. 150 (1940); Arizona v. Maricopa County Medical Soc'y, 457 U.S. 332 (1982); Catalano, Inc. v. Target Sales, Inc. 446 U.S. 643 (1980); Palmer v. BRG of Ga., Inc., 498 U.S. 46 (1990). 
and buyer. For example, the terms for extending credit have been classified as a price fixing agreement. ${ }^{54}$

The Supreme Court, however, has carved out one important exception to the per se treatment of horizontal agreements, even though such usually taboo subjects as price may be involved. The Court has approved agreements that are necessary to, or that facilitate, a workable market; a market that would not exist but for the arrangement under attack. ${ }^{55}$ These agreements are said to serve, rather than interfere with, the free market goal of efficiency and consumer welfare.

In the BMI case, the Court approved the agreement among composers to market their copyrighted creations through the joint venture arrangements that constitute BMI and ASCAP. The Court found that without these agreements among competitors, which included the formula for pricing and the nature of the product offered by the joint venture, no realistic market would have been available to the thousands of composers for their compositions. Thus, a new product was created that would not have been available to consumers without the agreement among competitor-composers. ${ }^{56}$

${ }^{54}$ Catalano, Inc. v. Target Sales, Inc., 446 U.S. at 648 ("It is virtually self evident that extending interest-free credit for purchases is equivalent to giving a discount equal to the value of the use of the purchase price for that period of time. Thus, credit terms must be characterized as an inseparable part of price. An agreement to terminate the practice of giving credit is thus tantamount to an agreement to eliminate discounts, and thus falls squarely within the traditional per se rule against price fixing."). See also Paramount Famous Lasky Corp. v. United States, 282 U.S. 30 (1930); United States v. First Nat'I Pictures, Inc., 282 U.S. 44 (1930).

${ }^{55}$ See Broadcast Music, Inc. v. Columbia Broadcasting Sys., Inc., 441 U.S. 1 (1979); National Collegiate Athletic Ass'n v. Board of Regents of Univ. of Okla., 468 U.S. 85 (1984) (dicta); Molinas v. National Basketball Ass'n, 190 F. Supp 241 (S.D.N.Y. 1961); National Bancard Corp. v. Visa U.S.A., Inc., 779 F.2d 592 (11th Cir.), cert. denied, 479 U.S. 923 (1986); Structural Laminates, Inc. v. Douglas Fir Plywood Ass'n, 261 F. Supp. 154 (D. Ore. 1966) affd 399 F.2d 155 (9th Cir. 1968), cert. denied, 393 U.S. 1024 (1969) (setting standards for products to facilitate marketing); United States v. Realty Multi-List, Inc., 629 F.2d 1351 (5th Cir. 1980); San Francisco Seals, Ltd. v. National Hockey League, 379 F. Supp. 966 (C.D. Cal. 1974); cf., N. Am. Soccer League v. National Football League, 505 F. Supp. 659 (S.D.N.Y. 1980) aff'd in part, rev'd in part, 670 F.2d 1249 (2d Cir.), cert. denied, 459 U.S. 1074 (1982) (finding that provisions of the agreement violated the antitrust laws). See generally, VII Areeda \& Turner, supra note 26, at ๆी 1478, 1504, 1505; Carlton \& Klamer, "The Need for Coordination Among Firms, with Special Reference to Network Industries," 50 U. Chi. L. Rev. 446 (1983).

${ }^{56}$ In theory a market was available. Each composer could have individually negotiated with each user of his/her compositions. As a practical matter, however, this was impossible on the massive scale of the entertainment industry. Moreover, composers had no ready means of policing any license that they had given, so protection and enforcement of their copyright interests was central to the justification for the agreement. 
It is important, however, to note that the agreement explicitly permitted any composer that wished to subscribe to the arrangement to become a participant. Thus there was no question of access by any competitor to the benefits of this marketing scheme. Also, most importantly, the participants were free to ignore the marketing arrangement and deal on their own. ${ }^{57}$ In other words, the arrangement was not exclusive. The Court found that this agreement facilitated competition, by creating a market that otherwise would not exist, rather than harming it.

This same basic idea was explored again in National Collegiate Athletic Ass'n v. Board of Regents of Univ. of Oklahoma. ${ }^{58}$ The Court, in dicta, approved of the basic agreement among otherwise competing colleges and universities creating the rules for amateur college athletics. Here, too, the Court found that without the collaborative activity, no market for amateur sports would exist. The basic agreement created, rather than harmed, competition. However, the Court went on to analyze that part of the agreement actually challenged in the case - the terms under which television broadcast rights for games were sold. The Court held these to be illegal because they were not related to, or necessary for, the basic market creating justification for the NCAA itself. In other words, the agreements were more restrictive of competition than was necessary to serve the market.

Thus, while joint action can be justified when necessary to facilitate a market, the terms of the agreement, to the extent they deviate from the free market model, must not exceed the minimum deviation necessary to make the market work. The justification cannot be used as an umbrella to cover practices not necessary to the market-serving rationale. As will be developed later, this concept and its limitations are critically important to the development of joint ventures in the public utility industries.

${ }^{57}$ This is important because if consumer welfare would be served in a particular instance by an ad hoc arrangement, the parties were free to negotiate a different deal. In other words, no party was being forced into a specific arrangement if they would be better off in a different arrangement.

${ }^{58} 468$ U.S. 85 (1984). 
An area of concern over the years has been the exchange among competitors of detailed information. ${ }^{59}$ It is recognized that the exchange of some information may improve the market and help to serve consumer's interests. ${ }^{60}$ Normal trade association exchanges of general market information have generally been permitted but are watched very closely to make sure the exchange of information is not used to facilitate a price fixing or output restricting agreement. We will return to this topic later, as it may be very important to current developments in the utility businesses.

Another group of cases in which a per se rule has often been applied involves agreements among competitors not to deal with some other business entity. These agreements are referred to as concerted refusals to deal and there is significant case law that holds such agreements per se illegal under Section One. ${ }^{61}$ Although courts frequently deal with such boycotts on their face, it should be noted that almost invariably the boycott is merely a means to an end. Arguably, it is the end that is

${ }^{59}$ See, e.g., American Column \& Lumber Co. v. United States, 257 U.S. 377 (1921) (plan requiring . members to report any price changes); United States v. Container Corp. of Am., 393 U.S. 333 (1969) (agreement to disclose most recent price offered when requested); United States v. United States Gypsum Co., 438 U.S. 422 (1978) (inter-seller price verification regarding specific customers); United States v. Airline Tariff Publishing Co., 1994-2 Trade Cas. (CCH) I 70,686 (D.D.C. 1994), judgment entered after settlement, 1994-2 Trade Cas. (CCH) I 70,687 (D.D.C. 1994) (dealing with the exchange of price change information among members of a joint venture of airlines that published fare data).

${ }^{60}$ In the economist's model of perfect competition all participants in the market have complete information, thus the exchange of information among competitors is irrelevant. In real markets, however, information is not always readily available and the exchange of information among competitors can facilitate overt or tacit collusion. However, in many instances having information will enhance the ability of a firm to compete. The difficulty is in drawing the line between the healthy exchange and that with anticompetitive consequences.

See Maple Flooring Mfrs. Ass'n v. United States, 268 U.S. 563 (1925) ("freight book" containing price, inventory, and sales information was permitted since the information did not reveal individual transactions); Cement Mfrs. Protective Ass'n v. United States, 268 U.S. 588 (1925) (information exchanged to prevent "fraudulent" bidding on contracts); Wilcox v. First Interstate Bank of Or., 815 F.2d 522 (9th Cir. 1987) (dissemination of prime interest rate information over wire services is permissible); Hanson v. Shell Oil Co., 541 F.2d 1352 (9th Cir. 1976), cert. denied, 429 U.S. 1074 (1977) (exchange of readily accessible public information is not a violation). See also VI Areeda \& Turner, supra note 26, at $\pi$ 1422.

${ }^{61}$ Fashion Originators' Guild of Am. v. United States, 312 U.S. 457 (1941); Klor's, Inc. v. Broadway-Hale Stores, Inc., 359 U.S. 207 (1959); Radiant Burners, Inc. v. Peoples Gas Light \& Coke Co., 364 U.S. 656 (1961); FTC v. Indiana Fed'n of Dentists, 476 U.S. 447 (1986); FTC v. Superior Court Trial Lawyers Ass'n, 493 U.S. 411 (1990). 
important for antitrust purposes, not the means, and some of the more recent cases have come to recognize that principle. ${ }^{62}$

Such agreements fall generally into two types; type one involves an agreement among some competitors to exclude another competitor from access to some beneficial position that the members of the agreement enjoy, for example, membership in a beneficial joint venture. ${ }^{63}$ The problem of appropriate access to such benefits is very important in the public utilities context and will be discussed in detail later. ${ }^{64}$

The second form of refusal to deal involves an agreement among competitors not to deal with one or more potential customers, that is, a vertical boycott. ${ }^{65}$ However, the refusal to deal, or threat of a refusal to deal, in a vertical relationship may well involve coercion of the target of the boycott to get that person not to deal with a competitor of those imposing the boycott. ${ }^{66}$ The anticompetitive effect is horizontal. Although this kind of agreement has been treated as per se illegal in many situations, in recent case law illegality has usually been limited to applications where the boycotting group has market power of some form. ${ }^{67}$ If the firm boycotted by the group has alternative sources with which to deal, because the boycotting group does not have

${ }^{62}$ See Northwest Wholesale Stationers, Inc. v. Pacific Stationary \& Printing Co., 472 U.S. 284 (1985); FTC v. Superior Court Trial Lawyers Ass'n, 493 U.S. 411 (1990) (boycott to enforce a blatant price fixing agreement); but cf., FTC v. Indiana Fed'n of Dentists, 476 U.S. 447 (1986) (the Court's analysis is ambiguous on this point).

${ }^{63}$ This is a direct horizontal boycott. Such cases may pose an appropriate application of the "essential facilities" doctrine in a collective action context. This doctrine also may be applicable in single firm monopoly situations under Section 2 of the Sherman Act. That aspect of doctrine will be discussed below in connection with monopolization.

${ }^{64}$ See infra note $227-43$, and accompanying text.

${ }^{65}$ Vertical arrangements in general will be treated below.

${ }^{66}$ See Fashion Originators' Guild of Am. v. United States, 312 U.S. 457 (1941); Radiant Burners, Inc. v. Peoples Gas Light \& Coke Co., 364 U.S. 656 (1961).

${ }^{67}$ See Northwest Wholesale Stationers, Inc. v. Pacific Stationary \& Printing Co., 472 U.S. 284, 296 (1985) ("Unless the cooperative possesses market power or exclusive access to an element essential to effective competition, the conclusion that expulsion is always likely to have an anti-competitive effect is unwarranted."); Rothery Storage \& Van Co. v. Atlas Van Lines, 792 F.2d 210 (D.C. Cir. 1986). 
market power, there is no injury to competition and the boycott will not be illegal per se. $^{68}$

If the boycotting group has market power, there will normally be per se illegality. Competition will either be injured in the buying market or, because the boycott is to coerce a buyer into not dealing with a potential competitor of the boycotting group, the injury to competition will be in the sellers market. However, it would appear that the courts will permit a refusal to deal where (1) its purpose is to enforce an agreement or rule that is otherwise legal and (2) the boycott goes no further than necessary to accomplish the permissible purpose.

Another area of concern under Section One is agreements forming joint ventures among competitors. ${ }^{69}$ These agreements may also fall under Section Seven of the Clayton Act scrutiny regarding the formation of the joint venture. The Court was at one time approaching virtual per se illegality for such cooperative action. ${ }^{70}$ However, in recent years it has been recognized that joint ventures can be very useful, and at times necessary, to get a market developed. ${ }^{71}$ Thus the case law has been more conducive to such ventures when they can be justified as necessary to the development of a better market or product. Moreover, to encourage innovation and development, Congress has specifically modified the antitrust laws as applied to certain joint

${ }^{68}$ See Northwest Wholesale Stationers, 472, at 298 ("When the plaintiff challenges expulsion from a joint buying cooperative, some showing must be made that the cooperative possesses market power or unique access to business element necessary for effective competition.").

${ }^{69}$ See, e.g., "Piraino, Reconciling Competition and Cooperation: A New Antitrust Standard for Joint Ventures," 35 Wm. \& Mary L. Rev. 871 (1994); Baker, "Compulsory Access to Network Joint Ventures Under the Sherman Act: Rules or Roulette?" 1993 Utah L. Rev. 999; Kattan \& Balto, Analyzing Joint Ventures' Ancillary Restraints, Vol. 8. \#1 Antitrust (ABA Section of Antitrust Law, Fall 1993); Pitofsky, "A Framework for Antitrust Analysis of Joint Ventures," 74 Geo. L.J. 1605 (1986); Brodley, "Joint Ventures and Antitrust Policy," 95 Harv. L. Rev. 1521 (1982).

70 See United States v. Penn-Olin Chem. Co., 378 U.S. 158 (1964); United States v. Topco Assocs., 405 U.S. 596 (1972); United States v. Sealby, Inc., 388 U.S. 350 (1967); American Fed'n of Tobacco Growers v. Neal, 183 F.2d 869 (4th Cir. 1950); Gamco, Inc. v. Providence Fruit \& Produce Bldg., 194 F.2d 484 (1st Cir.), cert. denied, 344 U.S. 817 (1952).

${ }^{71}$ See Piraino, "Reconciling Competition and Cooperation: A New Antitrust Standard for Joint Ventures," 35 Wm. \& Mary L. Rev. 871 (1994); Jorde \& Teece, "Innovation, Cooperation and Antitrust," 4 High Tech. L.J. 1 (1989). 
ventures. ${ }^{72}$ Congress and the courts have again been careful, however, not to let a valid justification serve to piggyback anticompetitive activity unnecessary to the central justification for the joint venture. ${ }^{73}$ If the predominant reason for the joint venture is to control price or marketing competition, its nature as a joint venture will not save it. ${ }^{74}$ The reason for the adoption of the joint venture form must relate to some efficiency in production or marketing that would otherwise be infeasible.

\section{Vertical Arrangements}

Section One deals not only with horizontal agreements but also with vertical agreements - those between buyer and seller. However, in the vertical context the courts have retreated significantly from the use of per se rules, treating most cases under the rule of reason approach. ${ }^{75}$

The major difference in treatment between horizontal and vertical agreements in modern case law is a recognition that vertical intrabrand, restrictive marketing arrangements may actually be an effective form of interbrand, horizontal competition. One participant in the vertical marketing chain is less likely to have an incentive to harm others in the vertical chain, as compared with competitors, since they are all dependent upon one another in reaching the ultimate consumers. It is much harder to draw an

\footnotetext{
72 See 15 U.S.C. $\S \S 4301-4304$. The Act initially only applied to research and development joint ventures. However, in 1993 the Act was amended to cover production joint ventures, as well.

${ }^{73}$ ld.; see cases cited in note 55 , supra.

74 Timken Roller Bearing Co. v. United States, 341 U.S. 593 (1951): Nor do we find any support in reason or authority for the proposition that agreements between legally separate persons and companies to suppress competition among themselves and others can be justified by labeling the project a "joint venture." Perhaps every agreement and combination to restrain trade could be so labeled.

75 See Continental T.V., Inc. v. GTE Sylvania, Inc., 433 U.S. 36 (1977); see also Monsanto Co. v. Spray-Rite Serv. Corp., 465 U.S. 752 (1984); Copy-Data Systems, Inc. v. Toshiba Am., Inc., 663 F.2d 405 (2d Cir. 1981) (involving a dual distribution situation); International Logistics Group Ltd. v. Chrysler Corp., 884 F.2d 904 (6th Cir. 1989), cert. denied, 494 U.S. 1066 (1990); Ryko Mfg. Co. v. Eden Servs., 823 F.2d 1215 (8th Cir. 1987), cert. denied, 484 U.S. 1026 (1988); Chuck's Feed \& Seed v. Ralston Purina Co., 810 F.2d 1289 (4th Cir.), cert. denied, 484 U.S. 827 (1987).
} 
automatic inference of bad motive or effect from the superficial evidence of conduct, which may appear on its face to interfere with the competitive market. One practice has remained clearly subject to per se illegality, however. Resale price maintenance, a form of price fixing, remains for the most part automatically illegal despite criticism by scholars and occasional reservations expressed by the courts. ${ }^{76}$ The continuation of per se illegality here may be primarily the result of clear political pressure from Congress. ${ }^{77}$

Tying arrangements, the practice of offering for sale one product or service only on the condition that another product or service be taken, have also been held illegal per se under Section One of the Sherman Act. Tying arrangements may fall within the coverage of Section Three of the Clayton Act, as well. ${ }^{78}$ For many years the courts took a very harsh view of tying arrangements in general, ${ }^{79}$ although some defenses were acknowledged. ${ }^{80}$ As the law has evolved, however, it has come to be recognized that only where the firm has power in the market for the tying product is the tying

${ }^{76}$ See Monsanto Co. v. Spray-Rite Serv. Corp., 456 U.S. 752 (1984) where the Court noted the criticism but reaffirmed the per se treatment of vertical price fixing. Two cases that appear to undercut the rule are Business Elec. v. Sharp Elec., 485 U.S. 717 (1988) (by implication) and Eastern Scientific Co. v. Wild Heerbrugg Instruments, Inc., 572 F.2d 883 (1st Cir. 1978), cert. denied, 439 U.S. 833 (1978). The Justice Department advocated retreat from the per se treatment in an amicus brief in the Monsanto case. Among the critical commentary on the rule is Posner, "The Next Step in the Antitrust Treatment of Restricted Distribution: Per Se Legality," 48 U. Chi. L. Rev. 6 (1981) (written after Spray-Rite but before Monsanto); Bork, The Antitrust Paradox, 280-298 (Basic Books 1978).

${ }^{77}$ Congress expressed it displeasure at the possibility of federal enforcement agencies advocating retreat from the per se treatment in several contexts, including a rider to an appropriation bill specifically forbidding the Justice Department from seeking to overturn the per se rule.

${ }^{78}$ However, Section 3 of the Clayton Act only applies where the transaction involves goods or commodities. It does not apply to services.

79 Northern Pac. Ry. v. United States, 356 U.S. 1, 4 (1958); International Salt Co. v. United States, 332 U.S. 392 (1947); International Business Machs. Corp. v. United States, 298 U.S. 131 (1936); United Shoe Mach. Corp. v. United States, 258 U.S. 451 (1922); but cf., Times-Picayune Pub. Co. v. United States, 345 U.S. 594 (1953).

${ }^{80}$ See, e.g., FTC v. Sinclair Refining Co., 261 U.S. 463 (1923); Pick Mfg. Co. v. General Motors Corp., 299 U.S. 3 (1936); United States v. Jerrold Elec. Corp., 187 F. Supp. 545 (E.D. Pa. 1960), aff'd, 365 U.S. 567 (1961); Dehydrating Process Co. v. A.O. Smith Corp., 292 F.2d 653 (1st Cir.), cert. denied, 368 U.S. 931 (1968). 
arrangement likely to have any effect upon the market for the tied product. ${ }^{81}$ In other words, if consumers have a realistic choice of other suppliers of the tying product, they are only likely to opt for the combination product if they choose that option.

The definition of market power in the tying context has not been clearly worked out. In Jefferson Parish, the Court held that 30 percent market share was not enough, but it is reasonably clear that the firm or group engaged in tying need not have monopoly power.

Moreover, the question whether there is a tie of two products or only one "bundled" product is also presented in many cases. ${ }^{82}$ The test that the majority of the Supreme Court uses in Jefferson Parish looks primarily at whether the two products or services could feasibly be marketed separately. One important item of evidence on this question is whether in fact the two are marketed separately by some. The minority position on the Supreme Court has been to look at whether consumers normally view the two products or services as separate or whether the consumer rarely buys the one without also buying the other. ${ }^{83}$ Alternatively, one looks to see if the two are sold in exact proportions to each other, in which case the two should be treated as one. ${ }^{84}$

In the recent Kodak case ${ }^{85}$ the Court reversed a summary judgment for the defendant, where the defendant had sold parts to some purchasers of its copying machines only if the purchaser also used the firm's repair service. It was alleged that tying service to the purchase of parts harmed competition in the independent service business and that Kodak had monopoly power in the parts market. Kodak defended on

${ }^{81}$ See, e.g., United States Steel Corp. v. Fortner Enter., 429 U.S. 610 (1977) (Fortner II); Jefferson Parish Hosp. Dist. No. 2 v. Hyde, 466 U.S. 2 (1984); Eastman Kodak Co. v. Image Technical Servs., Inc., 504 U.S. 451 (1992) (dicta); Mozart Co. v. Mercedes-Benz of N. Am., Inc., 833 F.2d 1342 (9th Cir. 1987), cert. denied, 488 U.S. 870 (1988).

${ }^{82}$ See, e.g., United States Steel Corp. v. Fortner Enter., 394 U.S. 495 (1969) (Fortner I); Jefferson Parish Hosp. Dist. No. 2 v. Hyde, 466 U.S. 2 (1984); Eastman Kodak Co. v. Image Technical Servs., Inc., 504 U.S. 451 (1992).

${ }^{83}$ This is the position taken in the dissent in Jefferson Parish.

${ }^{84}$ This was a major factor for the dissent in Kodak.

${ }^{85}$ Eastman Kodak Co. v. Image Technical Servs., Inc., 504 U.S. 451 (1992). 


\section{CHAPTER 3}

the ground that since it did not have market power in the underlying copy machine market, it could not have power in the aftersale parts market, it being directly tied to previous ownership of the Kodak equipment. Purchasers, it was claimed, would assess the long-run cost of machines coupled with service and arrive at a service life price to compare to the similar prices of other machines with which Kodak concededly competed. Calculated in this integrated way consumers have many options and Kodak, it was argued, did not have market power in the tying product; that is, parts for its machines.

It is important to note, however, that Kodak did not impose the tying arrangement on sophisticated buyers - those that had their own service capability. Moreover, the evidence demonstrated that many consumers were not happy with the forced choice and thought the independent service organizations were less expensive and qualitatively superior. Finally, the defendant made no attempt to justify the practice on any efficiency or proconsumer grounds. Had there been some logical explanation for the tying arrangement, consistent with a competitive market performance, the Court might well have allowed the summary judgment to stand. ${ }^{86}$

Given the traditional practice of bundling many services and products in the utility businesses, this area of antitrust concern may be very important in the new arenas of competitive markets. The topic will be discussed in greater specificity later. ${ }^{87}$

Exclusive dealing arrangements of various kinds - exclusive outlets, exclusive distributorships, exclusive or limited territorial clauses, exclusive customer clauses, and so forth - in the vertical chain of distribution may also fall under either Section One of the Sherman Act or Section Three of the Clayton Act. The law under both sections has developed virtually the same in recent years. Thus, in cases to which Section. Three does not apply, Section One can usually be used, always dependent, however, upon an "agreement" being present. Although in the earlier period, these practices had been

\footnotetext{
${ }^{86}$ Eastman Kodak Co., 504 U.S. at 484-86. See Mozart Co. v. Mercedes-Benz of N. Am., Inc., 833 F.2d 1342 (9th Cir. 1987), cert. denied, 488 U.S. 870 (1988).

${ }^{87}$ See notes $212-218$, infra, and accompanying text. Of particular importance in the electric power industry is the question of what constitutes different transmission services. That will be discussed at notes 214-218, infra.
} 
successfully challenged and the courts had approached per se illegality in a number of instances, ${ }^{88}$ it has now been recognized by scholars, government enforcement agencies, and the courts that such arrangements may often be a healthy part of interbrand competition and thus serve the consumer's interests and the goal of efficient marketing. ${ }^{89}$

The earlier law, reflecting concern about such arrangements curtailing competition because they might hurt a competitor or might foreclose outlets at another level of the marketing chain, has been significantly modified in recent years. Here, like tying cases, the courts now rely heavily upon a showing of market power before the practice will be condemned. Concern is limited to those situations in which market power may significantly curtail outlets or suppliers for competitors, which present a real threat to the competitive market structure itself, not just to intrabrand competitors.

These cases are now handled under a rule of reason approach with the anticompetitive potential weighed against the competitive gain.

\section{Monopolization and Attempts to Monopolize: Section Two of the Sherman Act}

Section Two of the Sherman Act prohibits monopolization and attempts to monopolize. It is aimed primarily at single firm behavior. ${ }^{90}$ Note that monopoly itself is

${ }^{88}$ See, e.g., Standard Fashion Co. v. Magrane-Houston Co., 258 U.S. 346 (1922); Standard Oil Co. of Cal. v. United States, 337 U.S. 293 (1949); United States v. Arnold, Schwinn \& Co., 388 U.S. 365 (1967); United States v. General Motors Corp., 384 U.S. 127 (1966); Timken Roller Bearing Co. v. United States, 341 U.S. 593 (1951).

${ }^{89}$ See Continental T.V., Inc. v. GTE Sylvania, Inc., 433 U.S. 36 (1977). See cases cited note 75, supra. See also the Department of Justice Vertical Restraint Guidelines, 50 C.F.R. 6263 (1985) (note should be taken, however, that these Guidelines were withdrawn shortly after the Clinton Administration took control in 1993). See generally, Vill Areeda \& Turner, supra note 26, at Chapter 16; Hovenkamp, supra note 26 , at $\S \S 11.2,11.6,11.7$.

${ }^{90}$ While Section 2 also makes illegal combinations and conspiracies to monopolize, these will also fall under Section 1 and, therefore, Section 2, as applied to such collective action, adds nothing and is seldom used as a practical matter. 
not made illegal. Rather, it is the act of monopolizing a market that is addressed. The courts have held that it is necessary to establish two elements:

"(1) the possession of monopoly power in the relevant market and (2) the willful acquisition or maintenance of that power as distinguished from growth or development as a consequence of a superior product, business acumen, or historic accident."191

Monopoly power is usually defined as an extreme case of market power - the ability to reduce output and raise prices above marginal cost for a sustained period of time. While theoretically it is possible to calculate the relevant marginal cost and to compare price and profit data to determine whether monopoly power is being exercised, as a practical matter such calculations are virtually impossible. Therefore, the courts have generally adopted a structural analysis as a surrogate. First, the relevant market must be identified and then the defendant's share of that market must be determined.

Establishing the relevant market here, as elsewhere in antitrust law, involves identifying both the product or service market involved and also the geographic market. The concept is relatively simple - one is trying to identify those available products or services that are fairly interchangeable in meeting the consumer's need or desire. Then, one is trying to determine the geographic area in which these substitutes are reasonably available to the buyer. This concept is referred to as the cross-elasticity of demand. If that cross-elasticity is high, then those substitutes are included in the relevant market. If the cross-elasticity is low, then they are not.

The goal, however, is to determine whether the defendant has sufficient market power to raise prices or curtail output. This involves, then, not only the cross-elasticity of demand, but also the cross-elasticity of supply. This part of the inquiry requires examining whether other firms, either presently in the market or potential entrants, would expand or enter with relative ease and take the business away from the defendant if the defendant were to try to raise price or reduce output. We are trying to

${ }^{91}$ United States v. Grinnell Corp., 384 U.S. 563, 570-71 (1966). See generally, III Areeda \& Turner, supra note 26, at Chapters 6, 7, \& 8; Hovenkamp, supra note 26, at Chapters 6 \& 7 . 
determine whether the buyer has a reasonable opportunity to turn to other sources to satisfy demand. Drawing the precise market is often very difficult and the courts make mistakes ${ }^{92}$ but nevertheless, one can usually do a pretty good job of approximating the relevant market analysis.

The next step is to figure the percentage of the just determined relevant market that the defendant controls. The percentage is usually based upon percent of sales, but in extraordinary circumstances, where sales is not a good indicator of power, percent of capacity or reserves or some other measure may be used. If the defendant's share is above about 70 percent it will be presumed that monopoly power exists. ${ }^{93}$

Once it is determined that the defendant has monopoly power, the analysis turns to the second issue: Has that power been used in an abusive manner? Here, too, the law has evolved significantly in recent years. In the 1950s and 1960s the courts came very close to applying a rule that would have meant that anytime a firm with monopoly power did anything, it would satisfy this requirement and the inquiry would move to

92 See, e.g., United States v. E.I. du Pont de Nemours \& Co., 351 U.S. 377 (1956); United States v. Grinnell Corp., 384 U.S. 563 (1966); United States v. Corn Products Ref. Co., 234 F. 964 (S.D.N.Y. 1916); cf., TV Communications Network, Inc. v. Turner Network Television, Inc., 964 F.2d 1022 (10th Cir.), cert. denied, 506 U.S. 999 (1992) (alleging monopoly market over one's own television network did not allege a relevant market). See generally, llA Areeda \& Turner, supra note 26 , at III 530,530a, 531a, 533c); Hovenkamp, supra note 26, at $\S 3.4$; Turner, "Antitrust Policy and the Cellophane Case," 70 Harv. L.. Rev. 281 (1956).

${ }^{93}$ The precise share of the market that constitutes monopoly power has never been specifically set. Rather the courts have talked in terms of ranges of power. Judge Hand's formulation in the Alcoa case is typical and often cited. He wrote:

[ninety] percentage is enough to constitute a monopoly; it is doubtful whether sixty or sixty-four percent would be enough; and certainly thirty-three percent is not.

United States v. Aluminum Co. of Am., 148 F.2d 416, 424 (2d Cir., sitting in lieu of the Supreme Court, 1945). See also United States v. Grinnell Corp., 384 U.S. 563, 571 (1966) ("In the present case, 87\% of the accredited central station service business leaves no doubt that the congeries of these defendants have monopoly power. . ."); American Tobacco Co. v. United States, 328 U.S. 781, 797 (1946) ("a substantial monopoly amounting to over two-thirds of the entire domestic field and over $80 \%$ of the field of comparable cigarettes. . ."); United States v. United Shoe Mach. Corp., 110 F. Supp 295 (D. Mass. 1953), aff'd, 347 U.S. 521 (1954).

See also, Metro Mobile CTS, Inc. v. Newvector Communications, Inc., 892 F.2d 62 (9th Cir. 1989) (firm with $100 \%$ of market does not have monopoly power if entry barriers are very low). 
defense or justification. ${ }^{94}$ However, the courts have generally backed away from this position recognizing that such an approach would virtually make monopoly itself illegal, rather than monopolization and would, in fact defeat rather than serve consumer welfare in some situations..$^{95}$ More recently, emphasis has shifted to the conduct, the "monopolization," part of the equation. One court has characterized the analysis as follows:

Like many courts and commentators, we refer to improper methods of acquiring or maintaining monopoly power as "exclusionary conduct." Borrowing from Professors Areeda and Turner, we have defined "exclusionary conduct" as "conduct, other than competition on the merits or restraints reasonably 'necessary' to competition on the merits, that reasonably appears capable of making a significant contribution to creating or maintaining monopoly power." ${ }^{.96}$

A major problem, recognized in many modern cases, is that of drawing the line between monopoly power innocently exercised simply to engage in a normal business activity (including monopolies that may have been innocently acquired, economically dictated, or even legally created, as in the case of a patent) on the one hand, and the abuse of that power, on the other. Much of what was once regarded as abusive or exclusionary behavior is now recognized as legitimate proconsumer activity, designed to keep or gain business by aggressively trying to attract customers with better prices,

94 United States v. Aluminum Co. of Am., 148 F.2d 416 (2d Cir., sitting in lieu of the Supreme Court, 1945). In United States v. Grinnell Corp., 236 F. Supp. 244, 247-48 (D.R.I. 1964), affd, 384 U.S. 563 (1966), Judge Wyzanski, at the trial level, found a violation under the conventional approach, but suggested, as an alternative, a rebuttable presumption approach once monopoly power is found.

95 Illinois, ex rel. Burris v. Panhandle E. Pipe Line Co., 935 F.2d 1469 (7th Cir. 1991), cert. denied, 502 U.S. 1094 (1992); Transamerica Computer Co. v. International Business Machs., 698 F.2d 1377 (9th Cir.), cert. denied, 464 U.S., 955 (1983); Memorex Corp. v. International Business Machs., 636 F.2d 1188 (9th Cir. 1980), cert. denied, 452 U.S. 972 (1981); California Computer Prods., Inc. v. International Business Machs., 613 F.2d 727 (9th Cir. 1979); Olympia Equip. Leasing Co. v. Western Union Tel. Co., 797 F.2d 370 (7th Cir. 1986), cert. denied, 480 U.S. 934 (1987); Berkey Photo, Inc. v. Eastman Kodak Co., 603 F.2d 263 (2d Cir. 1979), cert. denied, 444 U.S. 1093 (1980); Barry Wright Corp. v. ITT Grinnell Corp., 724 F.2d 227 (1st Cir. 1983); Telex v. International Business Machs., 510 F.2d 894 (10th Cir. 1975); SCM Corp. v. Xerox Corp., 645 F.2d 1195 (2d Cir. 1981), cert. denied, 455 U.S. 1016 (1982).

${ }^{96}$ Barry Wright Corp., 724 F.2d at 230, and referring to 3 Areeda \& Turner, supra note 26, ๆ 626 at 83 . 
higher quality, better service, and so forth - all actions that, if they succeed, are likely to hurt competitors or potential competitors, but at the same time produce performance that society wants to encourage, even when engaged in by a firm with market power. Thus the more recent cases have defined the conduct requirement as calling for conduct other than what would be consistent with normal market behavior in a competitive market. It is not enough that the conduct has an exclusionary effect. At least one court has also required that the conduct be such as could only occur as a result of the use of the monopoly power. ${ }^{97}$ It also is not enough that conduct hurts or disadvantages competitors or takes business away from them, if that happens as a result of a superior product, service, price, and so forth. This approach has made it much more difficult to make out a violation of Section Two.

Intent or motive have also played a strong role in Section Two jurisprudence. Courts had de-emphasized these elements in some earlier cases. ${ }^{98}$ In other cases, the result on the conduct issue turned on the apparent intent that accompanied the conduct, with the courts using evidence of motive to injure competitors as very persuasive in satisfying the bad conduct element. ${ }^{99}$

Most courts, however, have now recognized that intent to take business away from competitors, and therefore hurt them, is the essence of competitive behavior. Nevertheless, intent or motive evidence can still be persuasive in some situations and even recent cases have used such evidence to explain motive, and support a monopolization charge, where there is no attempt to explain or justify the conduct on

${ }^{97}$ See Telex Corp. v. International Business Machs., 510 F.2d 894 (10th Cir.), cert. dismissed, 423 U.S. 802 (1975).

${ }^{98}$ See, e.g., United States v. Aluminum Co. of Am., 148 F.2d 416, 432 (2d Cir., sitting in lieu of the Supreme Court, 1945):

[Where it has been established that the defendant has acquired monopoly power] the issue of intent ceases to have any importance; no intent. is relevant except. . .an intent to bring about the forbidden act. ... [N]o monopolist monopolizes unconscious of what he is doing.

${ }^{99}$ See, e.g., Lorain Journal Co. v. United States, 342 U.S. 143 (1951); Union Leader Corp. v. Newspapers of New England, Inc., 284 F.2d 582 (1st Cir. 1960), cert. denied, 365 U.S. 833 (1961); Great W. Directories, Inc. v. Southwestern Bell Tel. Co., 63 F.3d 1378 (5th Cir. 1995) (upheld jury verdict of predatory behavior based in part on intent to recapture lost business by getting "rid of some [competing] publishers" of phone directories), modified on reh'g, 74 F.3d 613 (1996) (damages for possible future violations are not permitted). 
any consumer welfare basis. ${ }^{100}$ In other words, where there is some evidence of anticompetitive motive or intent, the burden may well shift to the defendant to come forward with some justification or explanation for the conduct consistent with consumer welfare.

Section Two also covers attempts to monopolize a market. The elements of a cause of action under this heading have recently been re-articulated and interpreted by the Supreme Court: ${ }^{101}$

[T]o demonstrate attempted monopolization a plaintiff must prove (1) that the defendant has engaged in predatory or anticompetitive conduct with (2) a specific intent to monopolize and (3) a dangerous probability of achieving monopoly power. In order to determine whether there is a dangerous probability of monopolization, courts have found it necessary to consider the relevant market and the defendant's ability to lessen or destroy competition in that market:

To make out an attempt case today, therefore, one must prove predatory conduct, much like that discussed above as required under a monopolization charge, plus the specific intent in using that conduct to achieve a monopoly position, and, as a result of market structure analysis, evidence that the defendant is close to achieving that goal. Next we turn to specific areas of Section Two concern.

\section{Predatory Pricing}

One form of conduct that has generally been regarded as satisfying the conduct requirement of Section Two is predatory pricing. While few predatory pricing cases had

${ }^{100}$ See, e.g., Aspen Skiing Co. v. Aspen Highlands Skiing Corp., 472 U.S. 585 (1985); Berkey Photo, Inc. v. Eastman Kodak Co., 603 F.2d 263 (2d Cir. 1979), cert. denied, 444 U.S. 1093 (1980).

${ }^{101}$ Spectrum Sports, Inc. v. McQuillan, 506 U.S. 447, 456, (1993) (citation omitted). See also Colorado Interstate Gas Co. v. Natural Gas Pipeline Co. of Am., 885 F.2d 683 (10th Cir. 1989), cert. denied, 498 U.S. 972 (1990); Nugget Hydroelectric v. Pacific Gas \& Electric Co., 981 F.2d 429 (9th Cir. 1992), cert. denied, 508 U.S. 908 (1993) (a private power producer case); Pastore v. Bell Tel. Co. of Pa., 24 F.3d 508 (3d Cir. 1994). 
actually been brought until recent years, the practice was generally regarded as one of the prime examples of abusive use of monopoly power to achieve or preserve that power. Supposedly, a firm would lower its prices to a point where competition would be eliminated (or a competitor precluded from entering the market). The firm would then be able to raise its prices to a monopoly level, enjoying monopoly returns for a sustained period of time. In a path breaking article Professors Areeda and Turner analyzed the circumstances in which such a practice could succeed and found that only in rare circumstances did such a course of action make sense.

Areeda and Turner pointed out that putative predatory pricing always involves price cuts and therefore has a clearly proconsumer welfare aspect, at least in the short run. Moreover, it was often difficult to objectively distinguish between a predatory price cut and simple price competition; that is, a cheaper-cost firm taking advantage of its position to cut prices and take business away from its higher-cost competitors. They were clearly concerned that proceeding too aggressively against "predatory pricing" would chill healthy price competition. Thus, they proposed that only when the prices were below an appropriate measure of cost for a significant period of time should the prices be regarded as predatory. They argued that the most appropriate measure of cost should be marginal cost but, since use of marginal cost posed such difficult proof problems, ${ }^{102}$ that average variable costs should be used as an acceptable surrogate in most cases.

Areeda and Turner also pointed out that such a strategy was expensive to the firm engaging in the predatory pricing. The firm had to forego profits caused by the lower prices used to drive out or prevent the competition. This loss was presumably taken in anticipation of recouping those losses once competition was driven out of the market and prices could be raised to a monopoly maximizing level. Of course, the strategy would only make sense if the firm was assured that those higher later prices would not attract new entrants into the market that would force the price back down and make it impossible to recoup the loss and deprive the firm of the sought for long-term

\footnotetext{
${ }^{102}$ Marginal cost is the hypothetical cost of producing the next unit of production. Given its theoretical and hypothetical nature, it is very difficult to establish with precision in most situations.
} 
monopoly profits. Thus, there had to be present some combination of low exit barriers, making it relatively cheap to force competitors out, and high entry barriers, to prevent new competitors from being attracted to and entering the market once the firm raised its prices up to the monopoly level.

The legal rule that has generally emerged is that to present a predatory pricing case, satisfying the conduct requirement of Section Two, one must be pricing below average variable cost and there must be a reasonable expectation that the firm has some realistic possibility of recouping the short-term losses and maintaining the longterm monopoly profits. While the Supreme Court has now twice endorsed this approach in dicta, ${ }^{103}$ it has not directly ruled on the matter in a Section Two case. The lower courts have generally followed the approach, although the exact rules vary somewhat from court to court. ${ }^{104}$ The result is that today it is very difficult to present a successful predatory pricing case. As will be developed in more detail later, there are circumstances in the public utility industries where there may be more opportunity for successful predatory pricing. ${ }^{105}$

\section{Horizontal Merger and Acquisition Activity}

Early in the application of Section Two, several cases were brought in which the requisite conduct was proven by the mergers or acquisitions that established the firm's

${ }^{103}$ Brooke Group Ltd. v. Brown \& Williamson Tobacco Corp., 509 U.S. 209 (1993); Matsushita Elec. Indus. Co. v. Zenith Radio Corp., 475 U.S. 574 (1986).

${ }^{104}$ Barry Wright Corp. v. ITT Grinnell Corp., 724 F.2d 227 (1st Cir. 1983); Transamerica Computer Co. v. International Business Machs., 698 F.2d 1377 (9th Cir. 1983), cert. denied, 464 U.S. 955 (1983) (the court surveys the approach of the other circuit courts in footnote 8); Southern Pac. Communications Co. v. American Tel. \& Tel. Co., 740 F.2d 980 (D.C. Cir. 1984), cert. denied, 470 U.S. 1005 (1985); but see, McGahee v. Northern Propane Gas Co., 858 F. 2d 1487 (11th Cir. 1988), cert. denied, 490 U.S. 1084 (1989) (relying heavily on intent evidence); A.A. Poultry Farms v. Rose Acre Farms, 881 F.2d 1396 (7th Cir. 1989), cert. denied, 494 U.S. 1019 (1990) (relying on a structure/end-result test).

105 See notes 195-203, infra, and accompanying text. 
monopoly power. ${ }^{106}$ Clearly such conduct satisfied the requirement. After the passage of the Cellar-Kefauver Act in 1950, ${ }^{107}$ however, it became much easier to challenge mergers or acquisitions directly under the new merger law rather than proving a violation of Section Two. As a practical matter, therefore, cases relying on such conduct for a Section Two violation are now rarely brought. One aspect, however, may have special importance in the Section Two context, especially when combined with other suspect conduct. A merger or acquisition that is followed by closing down the plant and retiring equipment of the acquired firm suggests an intentional program of curtailing supply of the product - conduct at the very heart of concern about abuse of monopoly power. In such situations, a Section Two approach is clearly possible and may in some circumstances be preferable to a Section Seven case.

\section{Anticipating Demand Growth by Building Excess Capacity}

In the Alcoa case, ${ }^{108}$ one of the elements of conduct that the court found as proof of the abuse of monopoly power was the policy of Alcoa to anticipate demand with the construction of new capacity (and then incidentally work hard to create the demand to use the capacity). The court referred to this as an exclusionary practice, since it had the affect of preempting markets that might have otherwise attracted entry of competitors. This view has fallen into disfavor in recent years, however, because it obviously penalizes good planning and anticipation, even creation, of consumer demand. ${ }^{109}$ The approach also arguably accomplished little because the "monopolist" still had to price at or near competitive prices since high prices, irrespective of excess capacity, might invite new entrants to the market.

${ }^{106}$ See, e.g., Standard Oil Co. v. United States, 221 U.S. 1 (1911); United States v. United States Steel Corp., 251 U.S. 417 (1920).

${ }^{107}$ The Cellar-Kefauver Act of 1950 amended Section 7 of the Clayton Act, 15 U.S.C. $§ 18$.

${ }^{108}$ United States v. Aluminum Co. of Am., 148 F.2d 416 (2d Cir., sitting in lieu of the Supreme Court, 1945).

${ }^{109}$ See cases cited in note 95, supra. 


\section{Failure to Share New Research and Development}

It has been argued that a monopolist may entrench its position by engaging in significant research and development of new products and improvements in existing products. The argument is then made that the firm must, in order to avoid Section Two liability, predisclose to competitors or potential competitors such developments, perhaps with reasonable access to any patents that result. This argument was tried in a series of cases in recent years and the courts have almost uniformly ruled that this conduct does not satisfy the Section Two requirement, despite the fact that such conduct is clearly designed to, and in fact does, result in enhancing or re-enforcing monopoly power and excluding competitors. ${ }^{110}$ The point is that this conduct also promotes consumer welfare and such an interpretation of Section Two would chill research and development activity clearly in society's interest. Moreover, this is the perfect example of activity that is legitimately competitive and that anyone could engage in. There is nothing special about the presence of market power that makes innovation possible.

\section{Vertical Integration by Acquisition or Merger Foreclosing Markets to Potential Competitors}

This conduct is similar to an exclusive dealing arrangement, treated now generally under the rule of reason analysis. ${ }^{111}$ When market power is present, there is concern about the potential foreclosure of outlets or sources of supply for potential competitors in the monopolized market. Otherwise, there is little concern of an anticompetitive result. Moreover, since the integration may create efficiencies for the

${ }^{110}$ Berkey Photo, Inc. v. Eastman Kodak Co., 603 F.2d 263 (2d Cir. 1979), cert. denied, 444 U.S. 1093 (1980); Transamerica Computer Co. v. International Business Machs., 698 F.2d 1377 (9th Cir.), cert. denied, 464 U.S. 955 (1983); California Computer Prod. v. International Business Machs., 613 F.2d 727 (9th Cir. 1979); 3 Areeda \& Turner, supra note 26, at ๆ 738.3.

111 See Continental T.V., Inc. v. GTE Sylvania, Inc., 433 U.S. 36 (1977). 
firm, which are of potential benefit to society, such vertical integration does not carry the negative stigma it once did. This is reflected in the treatment of vertical mergers and acquisition in the most recent version of the Justice Department and FTC merger guidelines. $^{112}$

\section{Other Instances of Vertical Integration}

A related concern arises when the monopoly firm operates at more than one vertical level of an industry, whether as the result of acquisition or not. The concern is that the monopoly firm will engage in a price squeeze or supply squeeze, selling the monopolized good or service at a higher price to those competing with the firm at the other level of the distribution process than it "sells" to itself at "wholesale," thus permitting the retail level to underprice competitors. The theory behind this idea and its associated criticism is discussed elsewhere in this study in some detail. ${ }^{113}$ Suffice it to say here that in general this kind of conduct, while still suspect, is not now thought to pose as serious a threat in most instances as it once did. There is much greater concern that trying to prevent the behavior will lead to higher prices for consumers, either because the monopoly firm will not "lower" its prices in the retail market or because failure to permit the vertical integration will sacrifice efficiencies in marketing. Price squeezing is a course of conduct that has a special litigation history in the public utility field and will be discussed in more detail later in this study. ${ }^{114}$

${ }^{112}$ See 57 Fed. Reg. 41,552 (1992), announcing that there was no change in the Guidelines as related to vertical mergers since the 1984 Guidelines, 49 Fed. Reg. 26,834 (1984).

${ }^{113}$ See notes 102-05, supra, and 175-203, infra, and accompanying text.

${ }^{114}$ See notes $175-202$, infra, and accompanying text. 


\section{Tying}

Tying arrangements, discussed earlier, may also furnish the conduct requirement of Section Two but treatment of the practice is no different than under Section One and Section Three of the Clayton Act. ${ }^{115}$ The discussion will not be repeated here.

\section{Boycotts or Refusals to Deal}

There is substantial case law that holds that a refusal to deal or boycott may satisfy the conduct requirement when engaged in by a monopolist. ${ }^{116}$ The "boycott" may be either primary or secondary. ${ }^{117}$ While the general rule under the Colgate case doctrine, ${ }^{118}$ is that one may unilaterally refuse to deal with anyone, including a competitor, a series of cases has suggested that one holding market power has a special obligation not to behave in a way that prevents possible competition from developing or continuing. The Aspen Ski case, for example, appears to hold that a monopolist cannot refuse to deal, even with a direct competitor, if there is no legitimate business reason for the refusal, other than the mere desire to deprive the competitor of

${ }^{115}$ See notes 78-87, supra, and accompanying text.

${ }^{116}$ See, e.g., Aspen Skiing Co. v. Aspen Highlands Skiing Corp., 472 U.S. 585 (1985); Otter Tail Power Co. v. United States, 410 U.S. 366 (1973).

${ }^{117}$ A primary boycott is one in which the antitrust concern is for the market of the direct target of the boycott. See Otter Tail Power Co. v. United States, 410 U.S. 366 (1973). A secondary boycott is one in which a seller, for example, refuses to deal with a buyer unless the buyer refuses to deal with a competitor of the seller. Thus, the antitrust concern is for the market of the seller, but the buyer is being used as the means of achieving the goal. Lorain Journal Co. v. United States, 342 U.S. 143 (1951).

118 United States v. Colgate \& Co., 250 U.S. 300 (1919) ("In the absence of any purpose to create or maintain a monopoly, the act does not restrict the long recognized right of a trader or manufacturer engaged in an entirely private business, freely to exercise his own independent discretion as to parties with whom he will deal; and of course, he may announce in advance the circumstances under which he will refuse to sell."). 
business. In other words, the monopolist must justify the refusal to deal on some legitimate business basis.

One subset of the refusal to deal cases is referred to as the "essential facilities" doctrine. Access to essential facilities has become a most important issue in the modern public utility context. As a result, this doctrine and its ramifications will be discussed in substantial detail later in this study. ${ }^{119}$

\section{Price Discrimination: The Robinson-Patman Act}

Price discrimination is specifically covered by the Robinson-Patman Act. ${ }^{120}$ Passed in 1936 as a direct reaction to the impact of large firms on small businesses during the depression, its philosophy and language, at least under some interpretations, is inconsistent with the asserted goals of the other antitrust laws - putting trust in the workings of competitive markets. Nevertheless, most courts and the federal enforcement agencies, in recent years, have tried to enforce the price discrimination prohibitions so as to maintain consistency between the Robinson-Patman Act and the rest of the antitrust laws. ${ }^{121}$

To make out a case of illegal price discrimination, one must show that (1) a commodity of (2) like grade and quality was (3) sold to two different buyers (4) in interstate commerce (5) at different prices (6) where the affect may be substantially to lessen competition. In addition, if the action is brought by a private party seeking damages, the plaintiff must also prove that the price discrimination specifically caused the plaintiff damages. The courts have generally applied these requirements relatively

${ }^{119}$ See notes 244-55, infra, and accompanying text.

${ }^{120}$ Clayton Act Section 2, 15 U.S.C. § 13. See footnote [28] for the text of the Act.

121 See, e.g., Brooke Group, Ltd. v. Brown \& Williamson Tobacco Corp., 509 U.S. 209 (1993); United States v. United States Gypsum Co. 438 U.S. 422, 458 (1978) (the "Robinson-Patman Act should be construed so as to ensure its coherence with the broader policies that have been laid down by Congress" in the antitrust laws generally). 
strictly, which poses difficult threshold barriers to many price discrimination law suits. ${ }^{122}$ Three of the requirements may pose special questions in the public utility context, the commodity requirement, the like grade and quality requirement, and the requirement that at least one of the sales was made in interstate commerce (Note: not that it affected interstate commerce, the broader standard of the Sherman Act). These will be discussed in more detail later in this study. ${ }^{123}$

The Act also contains some express defenses. ${ }^{124}$ Price discrimination is not illegal if the lower price is offered to meet a lower price of a competitor. However, the

122 (1) "Commodities": The Act does not specifically define commodities, but the Act has been held to cover tangible products or goods and to not cover services, such as transportation; see Shippers, Inc. v. Southern Pac. Transp. Co., 673 F. Supp. 1005 (C.D. Cal. 1986), affd, 858 F.2d 567 (9th Cir. 1988), and nontangible products, such as securities. When both goods and services are included, the "dominant nature of the transaction" will govern. First Comics, Inc. v. World Color Press, Inc., 884 F.2d 1033 (7th Cir. 1989), cert. denied, 493 U.S. 1075 (1990).

(2) "Like grade and quality": see, e.g., FTC v. Borden Co., 383 U.S. 637 (1966).

(3) "Sold to two different buyers": see, e.g., Caribe BMW, Inc. v. Bayerische Motoren Werke, AG, 19 F.3d 745, 750-51 (1st Cir. 1994).

(4) "Different prices": see, e.g., FTC v. Anheuser-Busch, Inc., 363 U.S. 536 (1960); Texaco, Inc. v. Hasbrouck, 496 U.S. 543 (1990); but cf.,.Edward J. Sweeney \& Sons, Inc. v. Texaco, Inc., 637 F.2d 105 (3d Cir. 1980), cert denied, 451 U.S. 911 (1981); FLM Collision Parts, Inc. v. Ford Motor Co., 543 F.2d 1019 (2d Cir. 1976), cert. denied, 429 U.S. 1097 (1977).

(5) The "interstate commerce" requirement has been held to mean that at least one of the sales at issue must have been across state lines. See, e.g., Gulf Oil Corp. v. Copp Paving Co., 419 U.S. 186 (1974); Spencer v. Sun Oil Co., 94 R. Supp. 408 (D. Conn. 1950); McCallum v. City of Athens, Ga., 976 F.2d 649 (11th Cir. 1992) (involving a municipal water system).

(6) "Injury to competition"; see, e.g., Brooke Group, Ltd. v. Brown \& Williamson Tobacco Corp., 509 U.S. 209 (1993); Falls City Indus. v. Vanco Beverage, Inc., 460 U.S. 428 (1983).

(7) "Injury to plaintiff": see, e.g., J. Truett Payne Co. v. Chrysler Motors Corp., 451 U.S. 557 (1981); Interstate Cigar Co. v. Sterling Drug, Inc., 655 F.2d 29 (2d Cir. 1981).

${ }^{123}$ See notes $219-26$, infra, and accompanying text.

${ }^{124}$ Section 2(a) of the Robinson-Patman Act, 15 U.S.C. $§ 13(a)$, provides: [N]othing herein contained shall prevent differentials which make only due allowances for differences in the cost of manufacture, sale or delivery resulting from the differing methods or quantities in which such commodities are to such purchasers sold or delivered. ...

[N]othing herein contained shall prevent price changes from time to time where in response to changing conditions affecting the market for or the marketability of the goods concerned, such as but not limited to actual or imminent deterioration of perishable goods, obsolescence of seasonal goods, distress sales under court process, or sales in good faith in discontinuance of business in the goods concerned.

Section 2(b) of the Act, 15 U.S.C. $\$ 13(b)$, provides:

[N]othing herein contained shall prevent a seller rebutting the prima facie case thus made by showing that his lower price or the furnishing of services or facilities to any purchaser or purchasers was made in good faith to meet an equally low price of a competitor, or the services or facilities furnished by a competitor. 
lower price cannot be any lower than the defendant in good faith thought was necessary to meet the competitor's price. The Act also does not cover a price difference that reflects changed conditions affecting the marketability of the product such as perishable goods, obsolescence, distress sales, discontinuance from business, and the like.

The Act also provides a defense for different prices that reflect different costs of manufacture or distribution. However, this requirement has been read strictly and it is very difficult to establish the requisite difference in cost. ${ }^{125}$ The Supreme Court has also recently held that the fact that the different prices were used on sales to different levels in the distribution process is not a defense unless the different prices can be cost justified. ${ }^{126}$ Thus, "functional discounts," as such, are not permitted.

In addition to price discrimination itself, the Robinson-Patman Act also prohibits discriminatory brokerages, promotional and advertising allowances, and promotional services. ${ }^{127}$ Finally, Section Two(f) of the Act prohibits a buyer from knowingly inducing or receiving a discriminatory price that violates the Act. ${ }^{128}$

\section{Mergers and Acquisitions: Section Seven of the Clayton Act}

The Cellar-Kefauver Act of 1950 amended Section Seven of the Clayton Act to expand and clarify its coverage of mergers and acquisitions. The legislative history also reflects a high point in concern about size for its own sake and a "trend" toward concentration. As a result, antitrust law, and Section Seven specifically, was interpreted during the 1960 s in such a way that any significant merger - horizontal, vertical, or conglomerate (at least those conglomerate mergers that involved elimination

${ }^{125}$ See, e.g., United States v. Borden Co., 370 U.S. 460 (1962). In Texaco, Inc. v. Hasbrouck, 496 U.S. 543,561 (1990), the Supreme Court, in dicta, referred to the "rigorous requirements of the cost justification defense."

${ }^{126}$ Texaco, Inc. v. Hasbrouck, 496 U.S. 543 (1990).

${ }^{127}$ Robinson-Patman Act, Sections 2(c), (d), \& (e), 15 U.S.C. §§ 13(c), (d) \& (e).

${ }^{128} 15$ U.S.C. § 13(f). See, e.g., Great Atl. \& Pac. Tea Co. v. FTC, 440 U.S. 69, 78 (1979). 
of significant potential competition) - was highly suspect, if not per se illegal. ${ }^{129}$ The Act made illegal any merger or acquisition the effect of which "may be substantially to lessen competition, or to tend to create a monopoly." This language was read to include a strong policy of attacking trends toward concentration in their incipiency.

In the 1970s, thinking started to change and it was recognized that many mergers and acquisitions actually resulted in more efficient operations, beneficial to consumers, and did not necessarily result in anticompetitive structures. In fact, it was suggested that trends toward concentration probably were caused not by any anticompetitive objectives, but because cost factors created economies of scale in the industry involved. Also, mergers and acquisitions could be used as a very effective way to enhance the quality of management. Moreover, a strict construction hampers the sale of businesses that have either become inefficient or whose owners wish to cash in their investment and leave the market. Such a result perversely hurts business and a healthy economic market. Today, however, both the courts and the enforcement agencies are more demanding in their requirement that, in fact, the merger or acquisition does threaten competition and that significant efficiencies are not sacrificed by antitrust enforcement. ${ }^{130}$

As a practical matter, moreover, very few merger cases get litigated today. The Supreme Court has held that an injured competitor only has standing to bring a private suit if the competitor can show injury as a result of injury to the competitive process. ${ }^{131}$ It is not sufficient to show that one will be hurt by being underpriced by a more efficient firm emerging from the acquisition or merger; and, of course, a competitor is not hurt if

${ }^{129}$ See, e.g., Brown Shoe Co. v. United States, 370 U.S. 294 (1962); United States v. Pabst Brewing Co., 384 U.S. 546 (1966); FTC v. Proctor \& Gamble Co., 386 U.S. 568 (1967); United States v. Aluminum Co. of Am., 377 U.S. 271 (1964); United States v. Von's Grocery Co., 384 U.S. 270 (1966). In his dissent in Von's Grocery, Justice Stewart said: "The sole consistency that I can find is that in litigation under $\S 7$, the Government always wins."

${ }^{130}$ See generally, IV Areeda \& Turner, supra note 26 , at Chapters $9,10 \& 11$; Hovenkamp, supra note 26 , at $12 \& 13$.

${ }^{131}$ Cargill, Inc. v. Monfort of Colo., Inc., 479 U.S. 104 (1986); Brunswick Corp. v. Pueblo Bowl-O-Mat, Inc., 429 U.S. 477 (1977). 
the "mergered" firm will be charging higher prices. Thus, enforcement of merger law is now almost exclusively in the hands of the public enforcement agencies.

In addition, the 1976 Hart-Scott-Rodino Antitrust Improvements Act changed the whole world of merger law enforcement. ${ }^{132}$ On its face the Act appears to tighten federal enforcement by requiring firms of any size to notify the Justice Department or the FTC of any planned mergers and then to wait thirty days before consummation of the deal to allow time for the enforcement agencies to decide whether to challenge it. The practical effect has been to make every merger a matter of negotiation between the enforcement agency and the firms involved. Now routinely, if the enforcement agency finds problems with the merger, the firms either negotiate an acceptable solution, for example, by spinning off some part of the business that possesses a potential antitrust problem, or by dropping the merger on the grounds that it is not worth the cost to challenge the enforcement agency's objection. There is the possibility, however, that a state attorney general, suing in the capacity of parens patria, may challenge a merger, even though it has been approved by the federal enforcement agency. ${ }^{133}$

Turning to the substance of merger and acquisition law, here also developments have tended to take cases away from the litigation process. The federal agencies, as well as the National Association of Attorneys General, have, since the mid-1970s published merger enforcement guidelines, rather clearly setting out the situations in which mergers will be challenged. With this clarity of enforcement intentions, parties can avoid mergers and acquisitions that are likely to attract antitrust enforcement attention.

The federal guidelines for horizontal mergers and acquisitions ${ }^{134}$ are based primarily upon the policy objective of avoiding market structures that significantly

13215 U.S.C. $\S \S 1311-1314$.

${ }^{133}$ This too was provided for in the 1976 Hart-Scott-Rodino Antitrust Improvements Act, supra. See California v. American Stores Co., 495 U.S. 271 (1990).

${ }^{134}$ The most recent iteration of the Department of Justice Merger Guidelines, in which the FTC concurred, appear at 57 Fed. Reg. 41,552 (1992). They are reproduced in Appendix A to the 1995 Supplement to Areeda \& Turner, supra note 26. See generally, Id. at $\mid 901$; Hovenkamp, supra note 26, at $\S \S 12.1-12.8,441-497$. 
increase the possibility of successful express or tacit collusion among the firms, as well as those that actually approach monopoly power. The concern is to avoid mergers in markets that are highly concentrated or will become so as a result of the merger. In approaching the analysis, one must first define the relevant market, both product and geographic, and then using the Herfindahl-Hirschman Index $(\mathrm{HHI}),{ }^{135}$ one measures the current level of concentration in the market and the increase in that level that will result from the merger.

The guidelines provide that the relevant market will be determined by taking the product or service offered by the merging firms, assuming that it is the only firm in the market making that product, hypothesizing a "small but significant" price increase and then estimate the number of buyers that would shift to some substitute. If the number switching is relatively high, the demand for the product tested is relatively elastic and the relevant market must include the products to which these consumers switched. One keeps broadening the product market until one reaches a point at which, making the assumptions, few consumers would be willing to shift. That gives one the demand side of the analysis.

Next one looks at the supply side, this time estimating the number of firms that would enter the market if the target firm raised price by a small but significant amount. These potential entry firms are then added to the relevant market. The next step is to ascertain the target firm's share of relevant market identified. The same principles are used to determine the geographic market. ${ }^{136}$

${ }^{135}$ The HHI is calculated by first squaring the market shares of each competitor, expressed as a percent. These figures are then added to yield a single number expressing the level of concentration in the market. For example, in a market of five competitors, each with equal shares, the $\mathrm{HHI}$ is computed as: $\left(20^{2}+20^{2}+20^{2}+20^{2}+20^{2}\right)$, which equals 2000 . Larger HHls are indicative of a more concentrated market; smaller are indicative of a less concentrated market.

${ }^{136}$ See generally the discussion in Hovenkamp, supra note 26, at 463-97 (West 1994).

This approach has a couple of weaknesses. First, it relies to a substantial extent upon estimating in hypothetical situations. This obviously presents a large margin for error in identifying the relevant market. Second, it incorporates, to some extent, what has come to be referred to as the Cellophane Fallacy, named after the monopolization case in which the Supreme Court first used this basic approach. The analysis is fallacious because it assumes that the price at which the analysis starts is a competitive price. If the firm, either as a result of its monopoly power or express or tacit cartelization, is 
Once the relevant market is determined, the market shares of each of the firms in the market is identified, usually by sales volume but at times a more appropriate measure is used, such as production capacity. Then the market shares of the merging firms are identified. The federal guidelines set out the levels of concentration in the market and levels of increases in that concentration, as a result of the merger or acquisition, that may trigger greater concern and possible enforcement action to prevent the merger. ${ }^{137}$ However, in addition to the $\mathrm{HHI}$ itself, the guidelines suggest other market factors that may influence the ultimate enforcement decision. These nonmarket share factors include barriers to entry, ${ }^{138}$ adequacy of irreplaceable raw materials, ${ }^{139}$ excess capacity, degree of product homogeneity, marketing and sales method, and perhaps, whether either firm qualifies as a "failing company." ${ }^{140}$

\section{(... Continued)}

already charging a higher than competitive price, it will already be maximizing its position by charging a price in the elastic portion of the market demand curve, giving the appearance of a competitive market, but in fact capturing the maximum optimum monopoly rent. Nevertheless, this approach to identifying the relevant market is still valuable if the user keeps in mind consideration of the fallacy involved.

${ }^{137}$ The Guidelines since 1984 have provided that a post-merger HHI of less than 1000 is unlikely to be challenged. A clear safe harbor has been provided for mergers and acquisitions in unconcentrated markets. If the post-merger $\mathrm{HHI}$ is between 1000 and 1800 , the merger is unlikely to be challenged unless the increase in the $\mathrm{HHI}$ from before to after is greater than 100 , although the government will also consider the nonmarket share factors, discussed below, in making the decision. If the post-merger $\mathrm{HHI}$ is over 1800 and the increase is greater than 100 , the government is likely to challenge the merger or acquisition, unless the nonmarket share factors clearly suggest no anticompetitive threat (such as very low entry barriers). If the $\mathrm{HHI}$ is above 1800 but the increase is between 50 and 100 , the decision to challenge will rest on the nonmarket share factors. If the increase in the post-merger $\mathrm{HHI}$ is less that 50 , the government is not likely to challenge the merger or acquisition.

${ }^{138}$ See United States v. Waste Management, Inc. 743 F.2d 976 (2d Cir. 1984) (low entry barriers prevented prediction of adverse consequences); United States v. Baker Hughes, Inc., 908 F.2d 981 (D.C. Cir. 1990) (same); United States v. Country Lake Foods, Inc., 754 F. Supp. 669 (D. Minn. 1990) (same); FTC v. Elders Grain, 868 F.2d 901 (7th Cir. 1989) (entry barriers high because of need to have expensive, highly specialized plant with little salvage value). Recent monopolization cases treat potential entry similarly. See United States v. Syufy Enters., 903 F.2d 659 (9th Cir. 1990); Sunbelt Television, Inc. v. Jones Intercable, Inc., 795 F. Supp. 333 (C.D. Cal. 1992).

${ }^{139}$ See United States v. General Dynamics Corp., 415 U.S. 486 (1974).

${ }^{140}$ The "failing company" defense has a significant litigation history discussed in Hovenkamp, supra note 26 , at $494-97$. 
Vertical mergers and acquisitions are analyzed for the most part very differently. While the acquisition of monopoly power or the increase in concentration that might facilitate either tacit or express collusion is the main objective in horizontal merger law, the primary concern in vertical merger cases is possible foreclosure of the market for competitors. As the law has developed, what is important is the potential for making it much more difficult for competitors to find sufficient outlets at the next level of the distribution chain, either forward or backward, to permit the competitor to continue to compete on even terms.

In earlier times, these concerns led to very aggressive opposition to vertical mergers by both the courts and the federal enforcement agencies. ${ }^{141}$ In more recent years, it has been recognized that vertical mergers are probably most often undertaken in order to capture economies in the production and distribution process, rather than for any monopolization or anticompetitive purpose. ${ }^{142}$ While the Supreme Court has not spoken in a vertical merger case since 1972, the lower courts and the federal enforcement agencies have substantially abandoned opposition to vertical mergers, except in very extreme cases. ${ }^{143}$ The federal Guidelines provide that there will be no challenge to a vertical merger unless the firm already has substantial market power or the market is highly concentrated ${ }^{144}$ and the cost of entry by a potential competitor would be substantially greater because of a possible need to enter at both levels. The Guidelines, in addition, note that a merger or acquisition that provides the merged firm with the realistic potential to circumvent rate regulation may be challenged. ${ }^{145}$ Recently there has been some rethinking about the anticompetitive potential of vertical mergers

${ }^{141}$ See, e.g., Brown Shoe Co. v. United States, 370 U.S. 294 (1962); Ford Motor Co. v. United States, 405 U.S. 562 (1972); United States v. E.I. du Pont de Nemours \& Co., 353 U.S. 586 (1957).

142 See Bork, The Antitrust Paradox, 225-245 (Basic Books 1978); Hovenkamp, supra note 26, at $\S \S 9.1-9.5,329-349$; Ross, supra note 26, at 376-386; Landes \& Posner, "Market Power in Antitrust Cases," 94 Harv. L. Rev. 937 (1981).

${ }^{143}$ See Alberta Gas Chems. Ltd. v. E.I. du Pont de Nemours \& Co., 826 F.2d 1235 (3d Cir. 1987), cert. denied, 486 U.S. 1059 (1988).

${ }^{144} \mathrm{An} \mathrm{HHI}$ of at least 1800.

${ }^{145}$ See Vertical Merger Guidelines, 49 Fed. Reg. 26,834 (1984). 
and some renewed interest in possible enforcement has developed. ${ }^{146}$ The concern is still aimed, however, at the proper balance between efficiencies and the impact of such mergers on unintegrated competitors or potential entrants.

Conglomerate mergers, those between firms that are neither competitors nor in a buy-sell relationship with each other, have also seen a significant shift in enforcement approach in the past twenty years. While there was a time when mere size alone was thought enough to justify challenging conglomerate mergers and acquisition, today such a merger or acquisition will only be challenged by the federal authorities if it eliminates a strong potential entrant sitting on the edge of an otherwise concentrated industry. ${ }^{147}$ In one sense, this approach simply reflects the fact that the relevant market should have included this potential entrant and the problem can be handled at that level of the inquiry. Nevertheless, the federal guidelines still set out the potential competition merger as one that might be challenged under certain circumstances. In practice there has been little interest on the part of the enforcement agencies in conglomerate mergers and acquisitions in recent years and even the guidelines provide that no action will be taken unless the target market is a highly concentrated one. ${ }^{148}$

${ }^{146}$ See, "Report from Officialdom: 60 Minutes with Anne K. Bingaman, Assistant Attorney General, Antitrust Division, U.S. Department of Justice," 63 A.B.A. Antitrust L.J. 323, 327-28, 343 (Fall 1994); Stempel, "Moving Beyond the ' 84 Guidelines: Government Shows Increasing Concern with Vertical Mergers," 9 Antitrust 17 (ABA Section of Antitrust Law, Fall 1994); Riordan \& Salop, "Evaluating Vertical Mergers: A Post-Chicago Approach," 63 Antitrust L.J. 513 (1995).

${ }^{147}$ The courts have recognized two different types of potential competition mergers, the perceived potential entrant and the actual potential entrant. In the first case, the presence of the firm on the fringe of the market is viewed by the firms in the market as a potential competitor, perhaps even if the firm has never thought of entering, on the theory that the firm could and would get interested if price were raised to take a monopoly rent, making entry into the market profitable for the fringe firm. See, FTC v. Proctor \& Gamble Co., 386 U.S. 568 (1967); United States v. Falstaff Brewing Corp., 410 U.S. 526 (1973); Tenneco, Inc. v. FTC, 689 F.2d 346 (2d Cir. 1982) (court approved merger on the ground that entry barriers were so high that they made it unlikely that even the acquiring firm could be viewed as a potential entrant except by acquisition or merger). The actual potential entrant theory applies when there is evidence that the firm would have actually entered the market independently, creating a more competitive market, if the merger route of entry was unavailable. See United States v. Marine Bancorporation, Inc., 418 U.S. 602 (1974) (Court allowed merger despite evidence of entry interest because of the difficulty of de novo entry under state banking laws).

${ }^{148}$ With an $\mathrm{HHI}$ above 1800. 
The potential competition concept was first articulated by the Supreme Court in a merger case of special importance in the public utility industries and is worth a special note. The case was United States V. El Paso Natural Gas Co. ${ }^{149}$ El Paso had acquired stock in Pacific Northwest, another gas transmission company. El Paso and Pacific Northwest did not directly compete to deliver gas in any markets. However, several times Pacific Northwest had been the unsuccessful bidder to supply gas in the Southern California market where El Paso was an active seller. The Court challenged the acquisition and sent the case back to the District Court for a closer look at the potential competition concept. An important point of the case for present purposes is its recognition of an antitrust interest when there is competition in bidding for the right to serve, and only one firm can succeed.

${ }^{149} 376$ U.S. 651 (1964). 


\section{CHAPTER 4}

\section{AN EXCURSION INTO THEORIES OF ANTITRUST VIOLATIONS}

\section{Cartel, Monopoly, and Oligopoly Theory as the Basis for Antitrust Enforcement}

The basic thrust of the antitrust laws are bound up in the attempt to protect the public from firms, either singly (monopoly theory) or together (cartel and oligopoly theory), that impose or attempt to impose monopoly prices upon consumers. Such prices lead to the inefficient use of resources in satisfying consumer desires by diverting funds from more desired products and services that would be available if prices were set by a competitive market, that is, at or near marginal cost. These higher prices lead to a curtailment of supply of such goods and services to the detriment of society.

From the beginning it was recognized that collective behavior of competitors in a market could lead to such exploitation of the public welfare. Cartel behavior has become, perhaps, the clearest example of behavior the antitrust laws were designed to prevent. It is the most obvious situation in which the self interest of the firms involved can lead to the exercise of collective monopoly behavior. ${ }^{150}$ As a result, there has grown up a very strong presumption that whenever there is agreement among competitors it must be examined very closely to insure that the competitive process will not be defeated or compromised.

Similarly, exploitation of market power by a single firm monopoly is generally regarded as undesirable. However, here there are greater problems in identifying the culprit: What is a monopoly and do we have one here? What remedy is appropriate to

150 "People of the same trade seldom meet together, even for merriment or diversion but the conversation ends in a conspiracy against the public, or in some contrivance to raise prices." Adam Smith, The Wealth of Nations 232 (Pelican reprint 1980). 
the particular situation? How do we protect certain monopolies that are regarded as serving the public interest, for example patent monopolies?

A concern has developed regarding oligopoly behavior that may result in the same kind of exploitation of the consuming public. Oligopoly theory is premised upon the fact that where only a few firms dominate an industry or market, they are very aware of each other's behavior and it is highly interdependent. Through consciously parallel behavior the firms may maintain higher than competitive prices and curtail production or service. ${ }^{151}$ The behavior pattern is also completely consistent with each firm's individual interest, given the market structure. There is considerable dispute about how prevalent such behavior is and whether it can persist for very long in a dynamic market situation.

Over the years of antitrust enforcement there have been attempts to get at the oligopoly problem. Direct attempts have generally failed. A serious legislative initiative occurred in the late 1970s to deal with market structures that might give rise to oligopoly behavior, but the effort failed. The FTC attempted to confront the problem in a series of cases in the 1970s. These cases also ended up in failure. ${ }^{152}$

As noted earlier, the 1950 amendment of Section Seven of the Clayton Act was directed specifically to try to avoid mergers and acquisition that would create or exacerbate oligopoly market structures. The enforcement of Section Seven to this day reflects a primary concern for preventing oligopoly; that is, concentrated markets. This may be the only area in which enforcement has successfully dealt with oligopoly power.

One problem in dealing with oligopoly behavior, if the attempt is made under Section One of the Sherman Act, is the difficulty of establishing any "contract,

${ }^{151}$ Hovenkamp, supra note 26, at $\S \S 4.2-4.6,151-180$; Turner, "The Definition of Agreement Under the Sherman Act: Conscious Parallelism and Refusals to Deal," 75 Harv. L. Rev. 655 (1962); Turner, "The Scope of Antitrust and Other Economic Regulatory Policies," 82 Harv. L. Rev. 1207 (1969); Posner, "Oligopoly and the Antitrust Laws: A Suggested Approach," 21 Stan. L. Rev. 1592 (1969).

${ }^{152}$ See, e.g., E.I. du Pont de Nemours \& Co. v. FTC, 729 F.2d 128 (2d Cir. 1984); Boise Cascade Corp. v. FTC, 637 F.2d 573 (9th Cir. 1980); In the matter of Kellogg Co., 99 FTC 8 (1982), complaint dismissed; McDavid, "Oligopolies, Cereal and Section Five of the Federal Trade Commission Act," 61 Geo. L.J. 1145 (1973). 
combination, or conspiracy." ${ }^{.153}$ By definition the pricing policies are accomplished by independent, but interdependent, behavior. Nevertheless, competitors may enter into agreements or act in parallel fashion on matters other than price which facilitate the oligopoly pricing. Such "facilitating" behavior has been, from time to time challenged, with mixed results. ${ }^{154}$ The behavior that has been most often successfully attacked is the behavior that cannot be justified by any legitimate business objective. For example, both base point pricing ${ }^{155}$ and the exchange of very detailed information ${ }^{156}$ have been successfully challenged.

\section{The Leverage Theory}

During the period from the 1940 s to the early 1970 s a far reaching theory of antitrust liabilitly had developed in a series of cases, mostly, but not always, authored for the Court by Justice Douglas. ${ }^{157}$ This theory is now referred to as the leverage theory. It was premised on the misuse of market power and was used in applications of

text.

${ }^{153}$ The agreement requirement of Section One is set out supra, notes 37-38, and accompanying

${ }^{154}$ See generally, Salop, "Practices that (Credibly) Facilitate Oligopoly Coordination," in Stiglitz, New Developments in Market Structure (Macmillan 1985); Hovenkamp, supra note 26, at \$4.6, 170-180; Weiner, "Facilitating Practices: Distinguishing the Legitimate from the Unlawful," 7 Antitrust 22 (ABA Section of Antitrust, Summer 1993).

155 See FTC v. Cement Inst., 333 U.S. 683 (1948) (holding illegal a combination involving multiple base point pricing such that for any given locality, the price would be the same); see also Triangle Conduit \& Cable Co. v. FTC, 168 F.2d 175 (7th Cir. 1948) affd by an equally divided Court sub nom., Clayton Mark \& Co. v. FTC, 336 U.S. 956 (1949). Base-point pricing is a practice distinct from delivered pricing, which can be justified as having legitimate business purposes. For cases involving delivered pricing, see E.I. du Pont de Nemours \& Co. v. FTC, 729 F.2d 128 (2d Cir. 1984); Boise Cascade Corp. v. FTC, 637 F.2d 573 (9th Cir. 1980) (although on the facts, the case, perhaps, presented a basing point scheme rather than merely delivered pricing).

${ }^{156}$ See, e.g., United States v. Container Corp. of Am., 393 U.S. 333 (1969) (agreement to disclose most recent price offered when requested); cf., United States v. United States Gypsum Co., 438 U.S. 422 (1978) (interseller price verification regarding specific customers); Sugar Institute, Inc. v. United States, 297 U.S. 553 (1936) (exchange of price information and other agreed to practices).

${ }^{157}$ See, e.g., United States v. Griffith, 334 U.S. 100 (1948); United States v. Paramount Pictures, Inc., 334 U.S. 131 (1948); American Tobacco Co. v. United States, 328 U.S. 781, 797 (1946); Otter Tail Power Co. v. United States, 410 U.S. 366 (1973). 
both Sections One and Two of the Sherman Act and also Section Three of the Clayton Act. The basic idea was that power in one market was used to attain or preserve power in a second market. Thus, one who held a monopoly in one market, for example the result of a patent or copyright, would use that power to force consumers to buy products or services from the monopolist in a second, potentially competitive, market. This was said to violate Section Two because the use of the leverage was a predatory use of monopoly power to enhance or augment the monopoly power in the first market and thus satisfied the monopolization/conduct requirement of Section Two. Moreover, under Sherman Act Section One and Clayton Act Section Three, such use of leverage was regarded as clearly an "unreasonable" restraint of trade because it harmed competitors in the second market.

The leverage theory lies at the heart of many Section Two monopolization cases, most Sherman Act Section One and Clayton Act Section Three tying cases, many vertical exclusive dealing cases, and much of the jurisprudence involving both vertical and horizontal refusal to deal cases. By the early 1970 s the Supreme Court had so firmly adopted the theory that many per se violations were premised in part upon this basic idea of increasing market power by leveraging into related markets.

Critics, and then the courts, started to retreat from the more extreme applications of the leverage theory in the mid-1970s. ${ }^{158}$ The main thrust of the change in thinking involved the recognition that the use of leverage in and of itself could not, in most situations, add anything to market power. It would, at most, only dictate who would get the benefit of the already existing monopoly power.

${ }^{158}$ Actually the criticism started much earlier but began to attract significant attention in the 1970 s. Matsushita Electric Indus. Co. v. Zenith Radio Corp., 475 U.S. 574 (1986); Catlin v. Washington Energy Co., 791 F.2d 1343 (9th Cir. 1986); Alaska Airlines, Inc. v. United Airlines, 948 F.2d 536 (9th Cir. 1991), cert. denied, 503 U.S. 977 (1992). See generally, Bork, The Antitrust Paradox, Chapters 14 \& 15 (Basic Books 1978); Posner, Antitrust Law, Chapter 8 (1976); Kattan, "Developments - The Decline of the Monopoly Leveraging Doctrine," 9 Antitrust 41 (ABA Section of Antitrust Law, Fall 1994). Krattenmaker \& Salop, "Anticompetitive Exclusion: Raising Rivals' Costs to Achieve Power Over Price," 96 Yale L.J. 209 (1986) contains an excellent summary of the criticism. See also Hovenkamp, supra note 26, at $\$ 7.9,283-$ 85; Sullivan, "Section 2 of the Sherman Act and Vertical Strategies by Dominant Firms," 21 Sw. U. L. Rev. 1227 (1992). 
For example, in the Griffith case ${ }^{159}$ Justice Douglas was concerned that the defendant would use its monopoly position in towns where it was the only theatre, to force distributors of films to deal only with it in towns where it faced competition, thus hurting the competitor theatres in those other towns. However, the power in the monopoly towns only gave the defendant so much monopsony power. That power could be extracted from the distributor either in a price concession in that market or in the preferred position in the town where competition existed. But the distributor obviously would not concede to the monopoly position in the second town if it meant a loss to the distributor that was not outwieghed by some offsetting concession in the first market. Again the monopolist can only extract its monopoly power once. Thus, the argument goes that the total amount of power is not increased. Total output, prices, and power will stay the same, although they may be split differently between the two markets. The leverage has added nothing to the total market power or to the exploitation of consumers as a group.

The same argument can be made where the defendant has tied two products together. $^{160}$ The consumer demand curve for the package constrains the amount of monopoly rent that can be extracted from the tied set of products. If a desire to have the tying product is dependent upon the consumer also buying a tied product, which the consumer would not buy but for the tie, the buyer, as a practical matter, is going to subtract the price of the tied product from that which the buyer is willing to pay for the tying product. Again the use of the leverage does not alter the quantity produced or the total price to the consumer.

The tying requirement can hurt competitors in the second market but in general it does not change the performance that would be produced in the market - the output would not be reduced and prices to ultimate consumers would not be increased as a result of the leverage in most situations. The competitive structure of the market, as measured by performance, would not change. Only the identity of the participants in

159 United States v. Griffith, 334 U.S. 100 (1948).

${ }^{160}$ See generally, Wollenberg, "An Economic Analysis of Tie-In Sales: Re-examining the Leverage Theory," 39 Stan. L. Rev. 737 (1987). 
the market would change. Thus the practices might hurt competitors, but not competition.

The Supreme Court, as noted earlier, now articulates the guiding standard for application of the antitrust laws to be the protection of the competitively structured market place, not the protection of particular competitors. Thus, the leverage theory has had to be significantly reworked in recent years. The argument is made that the theory no longer has any validity, but that is too strong a characterization of where the courts are today. ${ }^{161}$ In many situations, there is still life in a modified version of the leverage theory.

One reason for its continued validity may be that the critique of the theory reflects too static an analysis of markets. Markets on both the demand and supply side are very dynamic, constantly susceptible to change. It can be argued that this dynamic nature suggests the desirability of protecting competitors in order to protect diversity in the firms available to react to changing circumstances. In other words, there is benefit to the competitive market place in preserving competitors when that is possible without sacrificing economic efficiencies, even though competitive performance in price and output would not change in the short run. This idea reflects the view that preserving diversity may enhance development of consumer choices over time and this is a value worth protecting unless it means sacrificing current consumer welfare.

Current consumers, however, should not be asked to subsidize inefficient markets just to protect competitors, as has happened in the past. If such sacrifice is not involved (that is, if there are no apparent efficiencies sacrificed), diversity in the market may be worth preserving as an end in itself. This is obviously a very different rationale than that underlying the populist approach of the Court during the middle of this century, described above, which was based more on a political view that small, independent business entities should be protected for their own sake.

${ }^{161}$ See Aspen Skiing Co. v. Aspen Highlands Skiing Corp., 472 U.S. 585 (1985); Eastman Kodak Co. v. Image Technical Servs., Inc., 504 U.S. 45 (1992); Brooke Group; Ltd. v. Brown \& Williamson Tobacco Corp., 509 U.S. 209 (1993) (dicta); Berkey Photo, Inc. v. Eastman Kodak Co., 603 F.2d 263 (2d Cir. 1979), cert. denied, 444 U.S. 1093 (1980); Kerasotes Mich. Theatres v. National Amusements, 854 F.2d 135 (6th Cir. 1988), cert. dismissed, 490 U.S. 1087 (1989); Advanced Health-Care Servs. v. Radford Community Hosp., 910 F.2d 139 (4th Cir. 1990). 
While the courts today no longer apply the leverage theory generally to protect competitors, it does continue to have considerable force in some situations. For example, tying law under Sherman Act Section One and Clayton Act Section Three is still quite powerful if the defendant has significant market power in the tying product. However, the courts do now require a showing of that significant power before condemning the tying arrangements, modifying the per se rule of earlier times to that degree. ${ }^{162}$ Even in the Section Two monopolization cases, the courts are probably still reluctant to allow leveraging of market power, unless some good business justification, aside from controlling the second market, is present. Cases turn on the possible consumer or efficiency justification rather than on the leverage power itself. ${ }^{163}$

Another set of cases in which it is still clearly recognized that the leverage theory may be applicable is where there is some imperfection in the market that does permit the monopolist to add to its power by leveraging power from one market into another. An example is the Court's analysis of the possible information market imperfection in the recent Kodak case. ${ }^{164}$

An example more directly relevant to the public utilities, and thus directly relevant to this study, may occur when price in the monopoly market is regulated so that the firm cannot extract the optimum monopoly rent in that market. The firm may try to leverage its monopoly power into another market that is unregulated, and take its full monopoly rent out in that second market. Here the firm can enhance its total monopoly rent and reduce output compared with what the performance would be if it faced competition in both markets and thus was unable to exploit its monopoly power. This was clearly the underlying situation in the Otter Tail case, although Justice Douglas in his opinion never

${ }^{162}$ See, e.g., United States Steel Co. v. Fortner Enters., Inc., 429 U.S. 610 (1977); Jefferson Parish Hosp. Dist. No. 2 v. Hyde, 466 U.S. 2 (1984).

${ }^{163}$ See, e.g., Aspen Skiing Co. v. Aspen Highlands Skiing Corp., 472 U.S. 585 (1985); Berkey Photo, Inc. v. Eastman Kodak Co., 603 F.2d 263 (2d Cir. 1979), cert. denied, 444 U.S. 1093 (1980); Telex Corp. v. International Business Machs., 510 F.2d 894 (10th Cir), cert. dismissed, 423 U.S. 802 (1975).

${ }^{164}$ Eastman Kodak Co. v. Image Technical Servs., Inc., 504 U.S. 45 (1992). 
directly relied upon this approach to the leverage theory in reaching the decision. ${ }^{165}$ Alternatively, when both markets are regulated to control the extraction of the monopoly rent, it will not, at least in theory, be possible to extract the monopoly rent in either market.

Yet another line of cases in which the leverage theory may still be alive and well, is the "anticompetitive intent" cases. The Supreme Court has long recognized probable liability where the defendant has engaged in leverage with a clear intent to injure competitors as part of a strategy to hurt the competitive market. ${ }^{166}$ It is the clear evidence of intent here that is critical. If it is truly present, it shows that at least the defendant believes that it is worthwhile to pursue the behavior, so the court can assume that an illegal effect may result.

The difficulty came in being certain of the clear predatory intent. The courts, as well as the commentators, have become very much aware of the fact that such evidence can be misinterpreted and must be viewed very cautiously. ${ }^{167}$ It may be difficult to distinguish between utterances that prove predatory, anticompetitive intent, as opposed to the same utterances reflecting healthy, robust competitive behavior. After all, in both cases the objective is to better one's competitors and take business

165 Otter Tail Power Co. v. United States, 410 U.S. 366 (1973). The case involved a refusal to deal. The leverage argument would have Otter Tail trying to enhance its monopoly power over transmission by capturing or preserving control over the retail market. Under conventional economic analysis, Otter Tail could have only taken its monopoly rent once, however, and thus if it was taking it at the wholesale level, or if rates at both levels were regulated, it would gain nothing by controlling the retail market, as well. The wholesale rate, in fact, was regulated by the Federal Power Commission (FPC [FERC's predecessor agency]), but at that time the retail rates were effectively not regulated. The case arose before Minnesota had adopted comprehensive rate regulation at the retail level. Thus Otter Tail could, at least in theory, extract the monopoly rent at the retail level that it was not able to take at the wholesale level, where it has the monopoly, by leveraging its power into the retail market.

${ }^{166}$ Aspen Skiing Co. v. Aspen Highlands Skiing Corp., 472 U.S. 585 (1985); Great Western Directories, Inc. v. Southwestern Bell Tel. Co., 63 F.3d 1378 (5th Cir. 1995) (involving publication of phone directories), modified on reh'g, 74 F.3d 613 (1996) (damages for future possible violations are not permitted).

167 See, e.g., Matsushita Elec. Indus. Co. v. Zenith Radio Corp., 475 U.S. 574 (1986); Brooke Group, Ltd. v. Brown \& Williamson Tobacco Corp., 509 U.S. 209 (1993); MCl Communications Corp. v. American Tel. \& Tel. Co., 708 F.2d 1081, 1114 (7th Cir.), cert. denied, 464 U.S. 891 (1983); Barry Wright Corp. v. ITT Grinnell Corp., 724 F.2d 227, 233-36 (1st Cir. 1983); cf., Note, "Intent as An Element of Predatory Pricing Under Section 2 of the Sherman Act," 76 Cornell L. Rev. 1242 (1991). 
away from them. Some courts now limit such "intent" evidence to situations where the behavior of the firm is clearly not in the firm's best interest except by its gaining market power as a result. With that caveat, the intent theory cases are probably still good law.

\section{The Foreclosure Theory}

From very early in the development of antitrust law, ${ }^{168}$ one of the concerns has been the ability of one firm, or group of firms in concert, to foreclose markets to competitors and thus increase or at least solidify market power. The foreclosure could be either forward into markets in which the defendant and its competitors sold or backward into markets from which the defendant and its competitors had to seek their products or their components. The argument holds that the ability to control such markets makes it more difficult for others to either continue or enter the primary market. A competitive firm would have to acquire its own outlets or sources of supply, making entry or continuation in the market more costly for the competitor or potential competitor. In addition, even if the defendant is not able to build more monopoly power as a result, the number of firms in the market is diminished, which might have an adverse effect upon the dynamic quality of the market — its innovation, adaptability, and so forth.

Most of the modern law dealing with vertical antitrust problems rests in large measure upon this foreclosure theory and, in general, requires a threshold showing of substantial market power on the part of the firm engaged in the foreclosure activity. It is generally thought now that harmful foreclosure is impossible without such significant power because competitors and potential competitors continue to have adequate

${ }^{168}$ In fact, one of the well-established offenses at common law upon which the antitrust laws were arguably premised, was the offense of forestalling, closely related to the modern concept of foreclosure. See Letwin, "The English Common Law Concerning Monopolies," 21 U. Chi. L. Rev. 355 (1954). The modern doctrine is explained and explored in an article reporting on an in-depth study, including interviews with witnesses, of the Lorain Journal case - Lorain Journal Co. v. United States, 342 U.S. 143 (1951). See Lopatka \& Kleit, "The Mystery of Lorain Journal and the Quest for Foreclosure in Antitrust," 73 Texas L. Rev. 1255 (1995). 
outlets for their products or sources for their supplies. ${ }^{169}$ Note that while this theory is used primarily in vertical cases - mergers, exclusive dealing, tying, exclusive outlets, and the like - the impact that is of concern is to the horizontal market; that is, injury to interbrand competition in the markets in which the defendant and the foreclosed firms primarily compete.

\section{New Strategic Behavior Theories}

In recent years several theories have been suggested aimed at identifying specific strategic behavior that may not involve price directly but that attempts to explain certain behavior and may lay a basis for antitrust concern. ${ }^{170}$ The two most frequently noted approaches are the application of game-theory economics ${ }^{171}$ and what is referred to as "raising rivals' costs."172 Neither has been clearly adopted by any court yet for the basis of an antitrust decision, although some of the literature has been cited. ${ }^{173}$

The raising rivals' costs theory has greater potential for use in antitrust enforcement decisions. It posits that an existing well-established firm can behave strategically in such a way that it is more expensive for much smaller rival firms or potential new entrants to operate than the firm engaging in the behavior. Many of the actual examples used to demonstrate the phenomenon, however, can be explained by

${ }^{169}$ See, e.g., Tampa Elec. Co. v. Nashville Coal Co., 365 U.S. 320 (1961); Jefferson Parish Hosp. Dist. No. 2 v. Hyde, 466 U.S. 2 (1984); Fruehauf Corp. v. FTC, 603 F.2d 345 (2d Cir. 1979). See generally, IV Areeda \& Turner, supra note 26, at ๆ 1004; Hovenkamp, supra note 26, at $§ 9.4$ (addressing the theory primarily in its vertical merger context); Ross, supra note 26, at 303-307.

${ }^{170}$ See generally, Baker, "Recent Developments in Economics That Challenge Chicago School Views," 58 Antitrust L.J. 645 (1989); Brodley \& Ma, "Using Insights from Game Theory: Penalty Contracts and Monopolizing Strategies," 9 Antitrust 6 (ABA Section of Antitrust Law, Fall 1994). 1989).

171 See, e.g., Rasmussen, Games and Information: An Introduction to Game Theory (B. Blackwell

${ }^{172}$ Krattenmaker \& Salop, "Anticompetitive Exclusion: Raising Rivals' Costs to Achieve Power Over Price," 96 Yale L.J. 209 (1986). See generally, Nonprice Predation Under Section 2 of the Sherman Act (ABA Antitrust Section, Monograph No. 18, 1991); Hovenkamp, supra note 26, at $\S 7.10,285-290$.

${ }^{173}$ Eastman Kodak Co. v. Image Technical Servs., Inc., 504 U.S. 451 (1992). 
protective government policies, the lobbying for which falls under the Noerr-Pennington Doctrine ${ }^{174}$ or by advantages resulting from economies of scale or scope.

${ }^{174}$ See notes $300-01$, infra, and accompanying text. 
. 


\section{CHAPTER 5}

\section{SPECIAL APPLICATIONS}

\section{Price Squeeze ${ }^{175}$}

The price squeeze is a classic example of the abusive use of market power. It is a specific example of predatory pricing, to be taken up next, and has produced a significant jurisprudence of its own since first suggested in the public utility context in the early 1970s. The underlying concept was recognized and articulated as a possible Section Two, Sherman Act, violation in the Alcoa Case. ${ }^{176}$ The basic idea is that suppliers dealing with customers, not only in that capacity, but also as a competitor in the customer's market, may price the product at wholesale so expensively that the buyer will find it impossible to compete with the lower price offered by the integrated seller. Of course, this is only possible if the seller has monopoly power in the wholesale market, precluding the buyer from simply turning to other wholesalers for its supply. Thus, a firm with market power in one market can drive out competitors in the other market and gain a monopoly in that market, as well.

However, as pointed out in the earlier discussion of leverage theory, ${ }^{177}$ a monopolist can normally only once take any monopoly profit permitted by the degree of price elasticity in the ultimate consumer market. It can take it out either at the

\footnotetext{
${ }^{175}$ Much of the following analysis is taken from the excellent treatment of the subject by Lawrence J. Spiwak, in his article, "Is the Price Squeeze Doctrine Still Viable in Fully-Regulated Energy Markets?" 45 Energy L. Rev. 75 (1993). See also Lopatka, "The Electric Utility Price Squeeze as an Antitrust Cause of Action," 31 UCLA L. Rev. 563 (1984).

176 United States v. Aluminum Co. of Am., 148 F.2d 416, 436-48 (2d Cir., sitting in lieu of the Supreme Court, 1945).

${ }^{177}$ See notes 157-68, supra, and accompanying text.
} 
wholesale level or at the retail level, or some combination, but only once. Thus, the monopolist's optimum price to the ultimate consumer will be the same whether the monopolist controls the second market or not. For this reason, a number of economists argue that from an efficiency, consumer welfare perspective, it makes no difference whether a price squeeze is used to force out competitors in the second level market. ${ }^{178}$ However, for reasons about to be explored, this reasoning does not necessarily hold in a regulated market.

Moreover, it is not clear in this context that efficiency economics should be the only concern taken into account. In the somewhat unusual market for public utility services, perhaps a somewhat stronger argument can be made for the need for local ownership and control and for diversity in management. ${ }^{179}$

By the mid-1970s smaller, frequently municipal, electric systems had become heavily dependent upon the vertically integrated, dominant investor-owned system in the area for the wholesale purchase of bulk electric power, as well as back-up emergency power. They began to complain that their suppliers were engaged in just the kind of price squeeze described above - pricing wholesale power to the buying system at prices higher than, as high as, or almost as high as the retail price that the wholesale firm was charging its retail customers or potential customers. Plaintiffs asserted that they were particularly harmed on sales or potential sales to large industrial customers choosing a location on the fringe of normal service territories where it was possible for the retail customer to take its service from either the wholesale purchaser or its wholesale supplier.

Cases were brought both in federal district courts, claiming a violation of Section Two of the Sherman Act, and in the FERC (originally the FPC) claiming that the rates were unfair. These cases tried to avoid the criticism of the Alcoa-type price squeeze

\footnotetext{
${ }^{178}$ Thus, the price squeeze theory set out in Alcoa has generally been in disrepute in recent years, since it affects only who gets the monopoly rent, not whether it can be taken at all. See generally, Ross, supra note 26, at 80-82; Hovenkamp, supra note 26, at \$7.6b, 268-70; Bork, The Antitrust Paradox, 243-44 (Basic Books 1978).

${ }^{179}$ See, e.g., Trebing, "Equity, Efficiency, and the Viability of Public Utility Regulation," in Sichel and Gies, eds., Applications of Economic Principles in Public Utility Industries (U. of M. 1981); Graniere, Post-Reform Continuation of Social Goals (NRRI Mono. \#96-07, 1996).
} 
case. While here both the retail and wholesale prices were regulated, and thus the seller should not, in theory, be able to take out the monopoly price in either market, the price at retail and the price at wholesale were regulated by two different agencies, one federal and one state. It was argued that it was possible to gain some of the monopoly rent by playing the state regulatory approach off against the federal regulatory authority, and vice versa, thus producing a total return higher than either authority would permit if it controlled both prices.

When the FERC was initially presented with a challenge to a wholesale rate by an intervenor - a wholesale customer/retail competitor - the agency held that it did not have jurisdiction to deal with the problem, other than to decide whether the wholesale rate was reasonable or not. It found that it could not adjudicate the antitrust, abuse of monopoly power, issue. ${ }^{180}$

The Commission, however, was reversed by the District of Columbia Circuit Court of Appeals, which, in turn, was affirmed by the Supreme Court. Those courts found that the Commission did have jurisdiction to determine whether a wholesale rate was in the public interest. A rate that was unfair because it caused injury to competition (that is, violated the antitrust laws), was not in the public interest. ${ }^{181}$ The Court did recognize a limit to the FERC authority. It could not set a rate so low as to be confiscatory, even if the rate set still put the buyer in a price squeeze. ${ }^{182}$ In other words, if the state-set rate was the one unreasonably out of line, the FERC did not have authority to force a confiscatory wholesale rate on the firm. Thereafter, in a series of cases, the FERC, along with the D.C. Circuit Court of Appeals reviewing the Commission's action, ${ }^{183}$ started considering the price squeeze idea and came to

${ }^{180}$ F.P.C. Order of Oct. 29, 1973, as described in Conway Corp. V. FPC, 510 F.2d 1264 (D.C. Cir. 1975), affd, 426 U.S. 271 (1976). Also see, Arkansas Power and Light Co., 54 F.P.C. 2812 (1975) (on motion for rehearing).

${ }^{181}$ FPC v. Conway, 426 U.S. 271 (1976), cf., Gulf States Utils. Co. v. FPC, 411 U.S. 747 (1973).

182426 U.S. at 279.

${ }^{183}$ Boroughs of Elwood City v. FERC, 731 F.2d 959 (D.C. Cir. 1984); Illinois Cities of Bethany et al. v. FERC, 670 F.2d 187 (D.C. Cir. 1981); Kansas Cities v. FERC, 723 F.2d 82 (D.C. Cir. 1983); Cities of Batavia et al. v. FERC, 672 F.2d 64 (D.C. Cir. 1982); Cities of Anaheim et al. v. FERC, 941 F.2d 1234 (D.C. Cir. 1991). 
articulate the circumstances under which it might find that a price was unreasonable in an alleged price squeeze situation.

Simultaneously, municipal system plaintiffs were bringing antitrust actions using the same theory in federal courts. The first major case, and perhaps the high point for price squeeze claims, was City of Mishawaka v. American Electric Power $\mathrm{Co}^{184}$ The lower court had found monopolization in violation of Section Two of the Sherman Act and had awarded damages of three times the difference between the wholesale rate to the plaintiff and the retail rate to retail customers. The Seventh Circuit affirmed the finding of a violation of Section Two but differed both as to certain critical elements of the appropriate legal rule and as to the relevant measure of damages.

The court began its analysis by acknowledging that regulation of the rate at both the wholesale and retail level made a price squeeze case considerably less likely to cause competitive harm. It also noted that in the regulated utilities, opportunities for normal competitive sales were substantially reduced, especially if potentially competitive sellers operated under a state-imposed scheme of exclusive retail territorial service. But the court pointed out that there was, nevertheless, competition for the franchise to serve the retail territory, for potential new customers, and for service on the fringe of territories. In fact, the court put special emphasis in its analysis upon the competition for the franchise, pointing out that over time the price disparity that the wholesale customers were complaining about had to make their franchises vulnerable.

The court found some evidence to suggest that, in fact, there was a concerted strategy on the part of American Electric Power (AEP), the wholesale seller, to acquire franchises that were having financial difficulty. The court also recognized that a firm acting strategically could whipsaw the regulatory processes at the state and federal levels, in such a way as to cause significant injury to competitors at the retail level. This was especially true given different rules and theories of regulation and timing under the different regulatory schemes.

The appellate court took issue, however, with the lower court's finding that in a monopolization case only a general intent, satisfied essentially by evidence that the firm

${ }^{184} 616$ F.2d 976 (7th Cir. 1980), cert. denied, 449 U.S. 1096 (1981). 
had monopoly power and exercised it in a way that harmed competitors, was all that was needed. ${ }^{185}$ The court seemed concerned that an "innocent" firm could get caught in the middle of this regulatory maze and unintentionally engage in a price squeeze. The court, therefore, held that in this special situation calling for an accommodation of the regulatory scheme controlling prices and the antitrust laws, a violation should only be found if there is more specific evidence of an intent to create, enhance, or extend monopoly power. If that were present one could more safely infer that the price squeeze was a strategic tactic. ${ }^{186}$

The court went on to find that there was sufficient evidence of the requisite intent here based in part on the nature and magnitude of the price squeeze. In addition, the court relied upon evidence that AEP had been warning its wholesale customers that they should seek other possible sources of power in case of a shortage on the AEP system because AEP intended to give preference to its own retail service areas. It was made apparent that, if the ultimate customers in these franchise areas wanted a secure supply of electricity, they might want to shift the retail franchise to AEP. Finally, the court relied upon evidence that AEP had in fact been buying up municipal franchises in the area from economically weakened municipal systems. While the court noted that none of this conduct alone would be sufficient to trigger a Section Two violation, together this congery of activities was sufficient for the lower court to infer intent on the part of AEP to behave strategically to enlarge its monopoly. ${ }^{187}$

${ }^{185}$ This interpretation was consistent with the then prevailing articulation of the requirements of Section 2, laid out in a series of Supreme Court cases, as well as the important decision of the Second Circuit sitting as the Supreme Court in the Alcoa case.

${ }^{186}$ The court said that:

In the particular circumstances, however, of a regulated utility struggling with dual regulation, bearing in mind that the utility is entitled to recover its cost of service and to provide its investors with a reasonable rate of return, we believe that something more than general intent should be required to establish a Sherman Act violation. . . The trial court discerned from a consideration of all the evidence of the utility's activities, not only a general intent which it considered to be adequate, but also a specific utility intent to serve its monopolistic purposes at municipal expense. We concur in that assessment of the evidence as a whole.

City of Mishawaka, 616 F.2d at 985.

187 "It is the mix of the various ingredients of utility behavior in a monopoly broth that produces the unsavory flavor." Id. at 986. 
On the damages issue the court held, similarly, that in these circumstances, where most possible competition, and therefore competitive injury, was going to be very different than in the normal competitive market place, the measure of damages had to be carefully tailored to the circumstances. Thus, instead of the difference between the two prices, the plaintiffs would have to show that they suffered actual injury in the sense of lost sales, lost opportunities, a loss of franchise (which none of them had), or some other specific injury. Part of the concern here was not to interfere with the relevant regulatory agency's finding of what was a reasonable rate, since at the federal level there had been partial rate relief granted, accompanied by refunds of the amount that had been collected over the granted rates during the pendency of the rate proceeding. While the court did not talk in terms of the filed rate doctrine ${ }^{188}$ the same principles seemed to be bothering the Seventh Circuit as it dealt with the remedy issue.

After the Mishawaka case, several other antitrust cases were brought using the theories of a Section Two violation articulated in that and the parallel FERC cases. However, in no other case has a court actually found a violation. In each case one or more of the problem areas recognized by the court in Mishawaka has been found determinative. ${ }^{189}$ Then, in 1990, the First Circuit, in an opinion by Judge, now Justice,

${ }^{188}$ Discussed at notes 282-91, infra, and accompanying text.

${ }^{189}$ See City of Groton v. Connecticut Light \& Power Co., 662 F.2d 921 (2d Cir. 1981) (court refused to address issue of whether there was a price squeeze; district court's narrow definition of competition may have led it to place burden on plaintiffs of showing anticompetitive effect); City of Kirkwood v. Union Elec. Co., 671 F.2d 1173 (8th Cir. 1982), cert. denied, 459 U.S. 1170 (1983) (defendant's alleged price squeeze is not protected from antitrust attack by the exclusive jurisdiction of state and federal regulatory agencies, the filed-rate doctrine, the state-action doctrine, and the NoerrPennington doctrine); Borough of Lansdale v. Philadelphia Elec. Co., 692 F.2d 307 (3d Cir. 1982) (no price squeeze because defendant did not have monopoly power in the relevant market; plaintiff had a number of options for obtaining the desired power); Borough of Ellwood City, Pa. v. Pennsylvania Power Co., 570 F. Supp. 553 (W.D. Pa. 1983) (price-squeeze claim remains viable despite previous FERC finding that price squeeze was not present; district courts can afford relief that FERC cannot provide); City of Malden, Mo. v. Union Elec. Co., 887 F.2d 157 (8th Cir. 1989) (because jury found that defendant did not possess monopoly power, court need not address issue of whether a Section Two monopolization claim requires general or specific intent); City of Anaheim v. Southern Cal. Edison Co., 955 F.2d 1373 (9th Cir. 1992) (for price squeeze violation to be found, must have something more than a mere price differential; specific intent is required).

THE NATIONAL REGULATORY RESEARCH INSTITUTE- 66 
Breyer, ${ }^{190}$ found, on balance, that a price squeeze should rarely if ever give rise to a Section Two violation. ${ }^{191}$ In reaching its decision, the court relied and elaborated on some of the same points that the court in Mishawaka had mentioned as troublesome. Specifically, Judge Breyer, in finding against the viability of a price squeeze case in most circumstances, pointed out the lack of much danger that such situations will really harm competition and the existence of the regulatory regime that can deal with the issues involved much more easily than the courts. According to the court, the agency also had a much better ability to accommodate antitrust concerns to the regulatory goals.

The court alternatively held that there was not sufficient evidence upon which the jury could have found that Boston Edison had monopoly power, a prerequisite of any Section Two case. Reviewing the evidence the court found that there were many alternative sources of wholesale power available to the plaintiffs, if wheeling of that power across Boston Edison's transmission lines was available. The record included substantial evidence that Boston Edison would have provided wheeling if asked. ${ }^{192}$ This part of the decision is particularly important in the emerging market for electrical power. With the development of a competitive market in electrical power generation,

${ }^{190}$ Town of Concord, Mass. v. Boston Edison Co., 915 F.2d 17 (1st Cir. 1990), cert. denied, 499 U.S. 931 (1991).

191 The court stated:

Effective price regulation at both the first and second industry levels makes it unlikely that requesting such rates will ordinarily create a serious risk of significant anticompetitive harm. At the same time, regulatory circumstances create a significant risk that a court's efforts to stop such price requests will bring about the very harms - diminished efficiency, higher prices that the antitrust laws seek to prevent. We conclude, therefore, that price regulation will, in most cases, prevent a price squeeze from constituting an "exclusionary practice" of the sort that Sherman Act $\$ 2$ forbids.

Id. at 19.

192 "[T]he record clearly demonstrates that Boston Edison will "'wheel' (i.e., transmit) electricity from other producers to any distributor upon request, all for a nominal transmission charge that no one claims is unreasonably high." Id. at 29. See also, City of Mt. Pleasant, lowa v. Associated Elect. Coop., Inc., 838 F.2d 268 (8th Cir. 1988) ("defendants had never denied any request that they wheel power to the City from outside sources"). 
and the emerging law and policy regarding transmission access for wheeling such power, it would appear that few price squeeze cases under the Mishawaka approach could be presented in the future, even without the first holding in Town of Concord. Rather, such cases will increasingly have to turn on the failure to get access to wheeling, dealing with the monopoly power over transmission, rather than relying upon monopoly power in the generation market. ${ }^{193}$

The few cases that have been decided since Town of Concord have generally been treated similarly, although stressing different points. ${ }^{194}$ Thus, it would appear that the courts' approach has made it very difficult to successfully pursue a price squeeze case in markets where both prices are regulated. However, the nature of the industries in this study are changing and we will be seeing many more situations in which one but not necessarily both markets may be subject to regulation and to those issues we now turn.

\section{Predatory Behavior in the Public Utility Context}

As noted earlier, ${ }^{195}$ while predatory pricing is generally thought to be rarely a successful strategy, in the public utilities it has greater potential. Predatory pricing could make economic sense and, therefore, pose a significant antitrust problem when

${ }^{193}$ This aspect is treated in more depth in the section on the essential facilities doctrine, infra, notes 244-55, and accompanying text.

194 See City of Anaheim v. Southern Cal. Edison Co., 955 F.2d 1373 (9th Cir. 1992), in which the court, while generally agreeing with the reasoning of Town of Concord, refused to go quite as far in articulating the difficulty of making out a case. Rather it stressed the specific intent of the pricing action as demonstrated, for example, by whether the defendant had any viable business explanation for the action, other than putting the plaintiffs at a competitive disadvantage. Thus the court, as the Supreme Court has recently in Kodak, see note 85, supra, and Aspen Ski, see note 100, supra, emphasized the absence of a legitimate business explanation as decisive. Where such a defense is presented it will offset the intent element of the monopolization conduct allegations. See also note 254 , infra.

${ }^{195}$ See notes 102-05, supra, and accompanying text. See also North Carolina Elect. Membership Corp. v. Carolina Power \& Light Co., 780 F. Supp. 322, 337 (M.D.N.C. 1991) (finding on the record presented that it was "implausible" that the firm had engaged in predatory pricing). 
the firm operates in both regulated and unregulated markets. It may be able to charge off to the regulated market (and thus be assured of recouping) costs, such as joint and fixed costs, that its competitors, only operating in the unregulated market could not avoid. Then the firm could charge a below cost price in the unregulated market, driving out the competition and recoup its losses in the regulated market. Of course, it can be argued that the regulatory authorities would not permit that kind of cost subsidization built into the regulated prices. However, it may be very hard for a regulatory agency to detect such subsidies. Moreover, from an economic point of view the assignment of such joint costs is purely arbitrary. The leverage created by the government sanctioned monopoly can also be used to gain nonprice advantages. ${ }^{196}$

In all three public utilities regulated and unregulated markets are emerging. For the foreseeable future, one may assume continued regulation of the cost of access to the local retail serving distribution systems - wire or pipe. Since that function will in most instances continue to be controlled by a monopolist, ${ }^{197}$ which also is offering unbundled products and services in the "competitive" market, the potential for the regulated firm to act predatorily against its competitors is present.

In Town of Concord, ${ }^{198}$ Judge Breyer briefly alluded to the problem faced when one of the markets involved is regulated and the other is not. The court recognized that in such situations there is much greater potential for a successful price squeeze or predatory pricing and specifically stated that the law might treat this situation very

${ }^{196}$ See Sievers \& Albery, "Strategic Allocation of Overhead: The Application of Traditional Predation Tests to Multiproduct Firms," 60 Antitrust L.J. 757 (1992); Noll \& Owen, "The Anticompetitive Uses of Regulation: United States v. AT\&T," in The Antitrust Revolution, at 290 (Kwoka \& White, eds., Scott, Foresman 1989).

${ }^{197}$ This is particularly true of electricity and gas, except, perhaps, for very large users. In telecommunications the situation is less clear. There are several viable alternatives in place or on the horizon. The growth of use of radio waves and satellites have certainly made inroads on the need for a wire connection. However, at present, cost differences still give wire service great advantages. In addition, competition between traditional telephone service and cable television service is at hand. However, at best this provides a tight oligopoly market, since it should be unthinkable to have multiple distribution networks. Sharing of that local distribution network on some kind of terms is essential. Thus, some form of regulatory control of that function will almost have to continue.

${ }^{198}$ Supra, note 190 , and accompanying text.

THE NATIONAL REGULATORY RESEARCH INSTITUTE - 69. 
differently. ${ }^{199}$ Most scholars, even those generally critical of the price squeeze approach and the more general leveraging idea, concede that one instance in which such conduct might lead to larger monopoly reward, and thus inefficient, anti-consumer welfare conduct, occurs when a firm can escape effective control of a regulated monopoly price.

Thus far, there has been relatively little clear litigation involving these kinds of price squeeze-leveraging ideas. However, a recent case in the Public Utilities Commission of Ohio illustrates the potential. It should be noted, however, that the decisions in the case thus far fall under the Ohio regulatory statute, not the antitrust laws, ${ }^{200}$ and the regulatory statute is considerably more specific in its application to the situation. ${ }^{201}$ The Commission found that the local electric company had entered into a contract to provide cooling service to a customer at a price below cost, ${ }^{202}$ making it

199 The court stated:

We recognize that a special problem is posed by a monopolist, regulated at only one level, who seeks to dominate a second, unregulated level, in order to earn at that second level the very profits that regulation forbids at the first. See 3 Areeda \& Turner [supra note 26, at] 1726 , at 217-20.

Town of Concord, Mass. V. Boston Edison Co., 915 F.2d 17, 29 (1st Cir. 1990), cert. denied, 499 U.S. 931 (1991). The same point is made in Judge Posner's opinion in Olympia Equipment Leasing Co. v. Western Union Tel. Co., 797 F.2d 370 (7th Cir. 1986), cert. denied, 480 U.S. 934 (1987). See also United States v. American Tel. \& Tel. Co., 524 F. Supp. 1336 (D.D.C. 1981). See generally, Ross, supra note 26 at 74-75.

${ }^{200}$ A parallel antitrust action raising the same issues has recently been filed in federal district court. See PUR Utility Weekly, October 6, 1995; "Ohio Edison Faces Antitrust Suit," Pub. Util. Fort. at 13 (December, 1995).

201 Youngstown Thermal Ltd. v. Ohio Edison Co., 163 P.U.R.4th 471 (Ohio P.U.C., Aug. 31, 1995), order clarified on reh'g in part, 165 P.U.R.4th 135 (Ohio P.U.C., Oct. 18, 1995). The case is currently pending on appeal to the Ohio Supreme Court.

The Ohio statute, R.C. 4905.26, provides in part that the Public Utilities Commission set for hearing and resolve any complaint against a public utility whenever reasonable grounds appear that "any rate, fare, charge. . .classification, or service rendered [or] charged. . .or proposed to be rendered [or] charged,. . . is in any respect unjust, unreasonable, unjustly discriminatory, unjustly preferential, or in violation of law. ..."

A similar situation may be posed when a telephone company with market power uses "predatory" tactics to make it difficult for competitive publishers of phone directories to compete. See Great W. Directories, Inc. v. Southwestern Bell Tel. Co., 63 F.3d 1378 (5th Cir. 1995), modified on reh'g, 74 F.3d 613 (1996) (damages for future possible violations are not permitted).

202 The case also illustrates the difficulty of deciding on the appropriate definition of cost in these predatory pricing cases. The Commission appears to have correctly used long-run avoided cost as its definition of "actual cost," below which the pricing had to fall to violate the statute. 
impossible for a potential competitor to bid successfully on the contract. The customer also took electric service from the defendant for other purposes. The Commission found that the price on the cooling service offered by the defendant was "predatory." It was being subsidized out of the profits from the portion of the total service that was regulated. The Commission expressly stated that was the reason why such predatory pricing, which in most situations might not make economic sense, would be in the firm's interest here. Thus, in any context in which a product or service is being sold in a competitive market but is closely related to a price regulated service, one must look very carefully at whether the power in the regulated market is being used to gain an enhanced position in the unregulated market and a monopoly rent, which otherwise could not be recovered, is now being extracted.

A number of cases have also been brought in recent years that involve independent power producers or similar non-utility generators. They have sued alleging predatory behavior by the dominant utility firm in the area that erected road blocks to their entry, growth, or development. In most of these cases the plaintiffs have lost, either because they could not prove a causal link between the utility's conduct and their financial plight or because the injury was the result of more efficient operations by the utility. The courts have recognized that this is not the type of injury the antitrust laws were designed to protect against. ${ }^{203}$

\section{Territorial Divisions}

As noted earlier, ${ }^{204}$ horizontal agreements to divide territories is one of the clearest per se violations of Section One of the Sherman Act. In the public utilities

${ }^{203}$ See, e.g., Nugget Hydroelectric v. Pacific Gas \& Elect. Co., 981 F.2d 429 (9th Cir. 1992), cert. denied, 508 U.S. 908 (1993) (also dismissed on state action grounds); Kamine/Besicorp Allegheny L.P. v. Rochester Gas \& Elec. Corp., 908 F. Supp. 1194 (W.D.N.Y. 1995). But see Long Lake Energy Corp. v. Niagara Mohawk Power Corp., 700 F. Supp. 186 (S.D.N.Y. 1988) (denying defendant a summary judgment on the issue).

${ }^{204}$ See note 53 , supra, and accompanying text. 
area, however, exclusive territorial integrity has long been a part of regulatory policy in many states. ${ }^{205}$ This policy reflected the view that competition at the local distribution level, at least, would be destructive and not in the public interest. With the unbundling of services and products and the changing market conditions at each level of distribution, that approach is subject to rethinking. As applied to unbundled products and services that are no longer directly related to the natural monopoly aspects of the business, the traditional idea of territorial exclusivity is out of place. There is already case law holding that, absent a clear state policy demanding exclusive territories, an agreement between two utilities not to compete in each others territories will be illegal. ${ }^{206}$ If one can clearly identify a natural monopoly submarket, there is continued validity to territorial division. Of course, when there is a clear state policy of territorial exclusivity, recent cases have continued to apply the state action doctrine $e^{207}$ to immunize such behavior. ${ }^{208}$

${ }^{205}$ See, for example, Fuchs v. Rural Elec. Convenience Coop., 858 F.2d 1210 (7th Cir. 1988), cert. denied, 490 U.S. 1020 (1989); Re Natural Gas Pub. Util. Serv. Expansion, 164 P.U.R.4th 589 (N.C.U.C. 1995); cf., Somerset Rural Elect. Coop. v. Pennsylvania Pub. Util. Comm'n, 641 A.2d 1249 (Pa. Commw. Ct. 1994). See generally, Phillips, supra note 10, at 120; 2 Kahn, The Economics of Regulation 8 (1988); Meeks, "Concentration in the Electric Power Industry: the Impact of Antitrust Policy," 72 Colum. L. Rev. 64, 95-99 (1972).

${ }^{206}$ See Consolidated Gas Co. of Fla. v. City Gas Co. of Fla., 880 F.2d 297 (11th Cir. 1989), cert. granted and judgment vacated after parties settled, 499 U.S. 915 (1991).

${ }^{207}$ For a discussion of the state action doctrine, see notes $277-81$, infra, and accompanying text.

${ }^{208}$ See Municipal Utils. Bd. v. Alabama Power Co., 21 F.3d 384 (11th Cir. 1994), cert. denied, 115 S.Ct. 1096 (1995); Columbia Steel Casting Co. v. Portland Gen. Elec. Co., 60 F.3d 1390 (9th Cir. 1995); Fuchs v. Rural Elec. Convenience Coop., 858 F.2d 1210 (7th Cir. 1988), cert. denied, 490 U.S. 1020 (1989); Praxair, Inc. v. Florida Power \& Light, 64 F.3d 609 (11th Cir. 1995). It is interesting to compare this case with the Consolidated Gas case cited in note 206, supra, since both involve an application of Florida law. In the case of electricity, the court found a clear articulation of a territorial integrity policy on the part of the state. However, in the case of natural gas, no such policy was found. Cf., Northwestern Bell Tel. Co. v. lowa Util. Bd., 477 N.W.2d 678 (lowa 1991) (state action protects exclusive dealing arrangement approved by public utilities commission). 


\section{Restrictive Vertical Distribution Policies and Tying Arrangements}

As noted earlier, ${ }^{209}$ the courts in recent years have held that for a non-price vertical distribution policy, such as an exclusive dealing arrangement or a full requirements contract, to be illegal under the antitrust laws, the defendant had to have substantial market power. The concern is that competitors will be foreclosed from adequate access to the controlled market and that consumers will not have adequate choice and, in the usual situation, that will only happen if the defendant has market power. ${ }^{210}$ Thus, several recent public utility related cases, presenting the context of the newly emerging competitive markets, have held that there was no violation because the defendant did not have sufficient market power. ${ }^{211}$

${ }^{209}$ See notes 78-89, supra, and accompanying text.

${ }^{210}$ As noted in the earlier discussion, the most important recent cases are Jefferson Parish Hosp. Dist. No. 2 v. Hyde, 466 U.S. 2 (1984) and Eastman Kodak Co. v. Image Technical Servs., Inc., 504 U.S. 451 (1992).

211 See, e.g., Continental Trend Resources, Inc. v. Oxy USA Inc., 44 F.3d 1465 (10th Cir. 1995) (allegation that pipeline company tied use of pipeline to use of compression and treatment plant - held, defendant only controlled about 10 percent of market and therefore tie not illegal); Consolidated Gas Co. of Fla. v. City Gas Co. of Fla., 880 F.2d 297 (11th Cir. 1989), cert. granted and judgment vacated after parties settled, 499 U.S. 915 (1991) (illegal tying found not to exist because of absence of market power where alleged tying involved tying bottled gas purchases to purchase of home).

Some recent cases have involved television programing and are perhaps relevant to the study as the telecommunications industry's potential for involvement in cable television programing increases. See Northeastern Educ. Television of Ohio, Inc., v. Educ. Television Assoc. of Metropolitan Cleveland, 758 F. Supp. 1568 (N.D. Ohio 1990) (exclusive licensing arrangement between television station and programming company was not in violation of the antitrust laws); Futurevision Cable Systems of Wiggins, Inc. v. Multivision Cable TV Corp., 789 F. Supp. 760 (S.D. Miss. 1992), affd without opinion, 986 F.2d 1418 (5th Cir. 1993) (exclusive dealing arrangement between cable system and program provider did not violate the antitrust laws). But see Storer Cable Communications, Inc. v. City of Montgomery, $826 \mathrm{~F}$. Supp. 1338 (M.D. Ala.), vacated at request of both parties, 866 F. Supp. 1376 (M.D. Ala. 1993) (allegations regarding exclusive dealing arrangement between cable operator and program supplier stated cause of action under antitrust laws). 
Turning to tying cases, recent cases have held that for the tie to be illegal, the party must have market power in the tying product. ${ }^{212}$ Perhaps, the most notable of these cases is the decision that led to the consent decree dismembering AT\&T. The court indicated that the long-time policy of AT\&T to tie the phone service with the use of AT\&T furnished equipment and the bundling of various services into a single product, presented a prima facie case of an illegal tying arrangement.

The AT\&T case probably illustrated the historic development of bundling at its most extreme. But the telephone business was not the only instance. The electricity and, to a lesser extent, gas industries were also marked by extensive combinations of various products and services into a single offering. The patterns were probably largely an outgrowth of historic technological interdependence and marketing evolution in each industry. Most importantly, perhaps, the transportation and delivery function was commonly tied to the sale of the product or service.

As noted earlier, recent developments have forced the unbundling of the various separate products and services in the interstate telecommunications industry and the interstate natural gas wholesale market. Unbundling is also rapidly being adopted at the state level for these two industries. Moreover, there is increasing attention to unbundling in the electric power market at both the federal and state level. The critical aspect, however, will be the likely continuation of pockets of market power, especially in local delivery systems, that could provide the monopoly power in the tying product.

With deregulation, the potential for tying arrangements to re-establish these bundling practices is present when significant market power remains. There may be real economies in some tying arrangements, and consumers may voluntarily opt for the

${ }^{212}$ See, e.g., United States v. El Paso Natural Gas Co., 1995 WL 623097, Util. L. Rep. (CCH) II 14,062 (D.D.C. 1995) (tying meter installation to natural gas gathering services); Yeager's Fuel, Inc. v. Pennsylvania Power \& Light Co., 22 F.3d 1260 (3d Cir. 1994) (possible tie between energy saving heatpump and other promotional programs to "all electric service" agreement).

See also, United States v. American Tel. \& Tel. Co., 524 F. Supp. 1336, 1348-1352, 13791380 (D.D.C. 1981). These aspects of the AT\&T case, as well as others, are discussed in depth by two of those directly involved in framing the government's case in Noll \& Owen, "The Anticompetitive Uses of Regulation: United States v. AT\&T," in The Antitrust Revolution, at 290 (Kwoka \& White, eds., Scott, Foresman 1989). For a description of the AT\&T policy with regard to equipment, challenged in an antitrust case the opinion in which deals with other matters, see Phonetele, Inc. v. American Tel. \& Tel. Co., 664 F.2d 716 (9th Cir. 1981), cert. denied, 459 U.S. 1145 (1983). 
bundled service or product. These should survive antitrust concern, at least where they are also available unbundled so that consumers are provided the opportunity to buy separately. The courts and the enforcement agencies will have to be very alert to possible abuse, however.

A critical problem is to distinguish in any given situation whether one is dealing with a single product or service or multiple products and services that are tied. As noted earlier, ${ }^{213}$ the prevailing test used by the Supreme Court currently is whether a market exists or could exist for the products or services in their separate state.

Applying this test to the public utility contexts is not easy. The products and services tend to be closely related and different consumers may view the situation quite differently. We have already decided many of these questions in the telecommunications industry. For example the AT\&T case clearly established that long distance and local service are two separate products, even though long distance service is difficult without access to the local service network to reach the originator of the call and the destination for the call.

Similarly, it is now clear that generation, transmission, and distribution are different services in the electricity industry. In gas, production, gathering, long-distance transportation, storage, and local distribution can be marketed separately. Finally, there is clear recognition today that the transport function can be offered separately from the sale/marketing function.

Many difficult questions remain, however. For example, in the electric power industry is the reserve component of service separable from base service? Is access to the entire network different than "point-to-point" service? Can stranded investment be tied to access to the transmission bottleneck?

The recent Cajun Elec. Power Coop. case illustrates this problem. ${ }^{214}$ The case specifically only dealt with whether the FERC had to provide a hearing upon a rate filing. That turned upon whether there were disputed questions of fact. Entergy Corporation provided wholesale electric power to the Cajun Electric Power Cooperative

\footnotetext{
${ }^{213}$ See notes $82-84$, supra, and accompanying text.

${ }^{214}$ Cajun Elec. Power Coop. v. FERC, 28 F.3d 173 (D.C. Cir. 1994).
} 
and many other wholesale customers. Entergy filed proposed rates with the FERC which unbundled the sale of the bulk power itself from the transmission function. In general, these rates were designed to implement the policy objective of the FERC to promote greater competition at the generation/wholesale level by separating the merchant function from the transmission function. However, Entergy had included in the rates the "stranded investment" costs to Entergy. Stranded investment cost "are the costs Entergy incurs due to any surplus in generation (or other) facilities resulting from introduction of open access to its transmission service."215 In other words, "if Entergy loses a customer of generation capacity to a competitor but the customer continues to employ Entergy's transmission grid, the charge for the transmission will include not only costs directly associated with it, but also the cost of Entergy's generation capacity idled by the switch." ${ }^{216}$

This involves policy concerns over the transition to competitive markets beyond the scope of this report. However, the interesting aspect of the court's opinion for present purposes is the court's characterization of this problem as involving regulatory approval of a tying arrangement. The court said

both parties agreed. . . [that] the primary source of Entergy's market power in generation sales is its bottleneck monopoly in transmission services. Given this market power, a classic tying problem exists: Entergy could use its monopoly over transmission services to eliminate competition in the market for generation services....

.. [l]f a company can charge a former customer for the fixed cost of its product whether or not the customer wants that product, and can tie this cost to the delivery of a bottleneck monopoly product that the customer must purchase, the products are as effectively tied as they would be in a traditional tying arrangement. ${ }^{217}$

\footnotetext{
${ }^{215}$ Id. at 175.

${ }^{216}$ Id. at 177.
}

${ }^{217}$ Id. at 176, 178. The Massachusetts Department of Public Utilities has recently decided that combining stranded costs with regular transmission rates was not a tying arrangement raising antitrust problems. Re Cambridge Electric Light Co., 164 P.U.R.4th 69 (Mass. D.P.U. Sept. 8, 1995). 
In other contexts, other courts have dealt variously with whether differences in transmission services made them separate products. ${ }^{218}$

\section{Price Discrimination under the Robinson-Patman Act $^{219}$}

\section{A price discrimination charge under the Robinson-Patman $A c{ }^{220}$ frequently} accompanies a price squeeze or predatory pricing allegation, as well as occasionally being the primary basis for an alleged cause of action. As noted earlier, ${ }^{221}$ the Robinson-Patman Act may be violated anytime there are sales of a commodity of like grade and quality to two different buyers at different prices where the affect may be substantially to lessen competition. The Act also requires that at least one of the sales be in interstate commerce. Unlike Sherman Act violations, which only require that the transaction involved affect interstate commerce, under the Robinson-Patman Act, one of the sales must actually be in interstate commerce. ${ }^{222}$ Given the local nature, at least traditionally, of most retail utility sales, this requirement will often present an impediment to a Robinson-Patman Act allegation in the industries under study. Today, on the other

${ }^{218}$ For example, granting a summary judgment under the "filed rate doctrine," a lower court has held that point-to-point service and network service are the same products. However, the Circuit Court on appeal held that the issue presented a question of fact, which could not be decided on a summary judgment. Florida Mun. Power Agency v. Florida Power \& Light Co., 839 F. Supp. 1563 (M.D. Fla. 1993), rev'd and remanded for factual hr'g, 64 F.3d 614 (11th Cir. 1995) (discussed in depth at note 286, infra, and accompanying text.)

${ }^{219}$ Unjust or unreasonable price discrimination is almost always prohibited by the rate regulation provisions of regulatory acts applicable to the public utilities under study here. However, the law under that regulatory prohibition is quite different than under the Robinson-Patman Act and will not be discussed here. See Phillips, The Regulation of Public Utilities, Chapter 10 (3d ed. 1993). See also Henderson \& Burns, An Economic and Legal Analysis of Undue Price Discrimination (NRRI Mono. \#89-12 1989), Chapter 3.

22015 U.S.C. 13.

${ }^{221}$ See notes $120-23$, supra.

${ }^{222}$ (1974); McCallum v. City of Athens, Ga., 976 F.2d 649 (11th Cir. 1992) (involving a water utility system); S \& M Materials Co. v. Southern Stone Co., 612 F.2d 198 (5th Cir. 1980). See generally, "Note, Antitrust Law - Robinson-Patman Act - To Satisfy the 'In Commerce' Requirement of Section 2(a) at Least One of the Allegedly Discriminatory Sales in a Secondary-Line Case Must Cross A State Line," 27 Vand. L. Rev. 539 (1974). 
hand, there is less chance of failing this test where wholesale transactions are involved or in the developing direct interstate retail market.

A Robinson-Patman violation must involve sales of a commodity. In the public utility context this requirement becomes problematic. The sale of telecommunication services, including cable service, has been, almost universally, held to involve the sale of services and not commodities, thus taking such transactions outside the scope of the Robinson-Patman Act. ${ }^{223}$ On the other hand, while there is very little case authority, it is almost certain that the sale of natural gas does involve a commodity. ${ }^{224}$ Turning to electricity, the courts are split but a majority appear to hold that the sale of electricity involves a commodity and thus the Robinson-Patman Act does apply. ${ }^{225}$

The rapid changes occurring in these industries makes the law on the subject quite open to question, however. The primary change is the unbundling of products and services that is occurring, either voluntarily or as a result of regulatory action. For example, as the interstate pipeline industry shifts from a predominantly market function to a transportation function, the prevailing view that the sale of gas involves the sale of a commodity becomes obsolete, as far as the pipeline function is concerned. It has long been held that the provision of the transportation function did not involve the sale

${ }^{223}$ See, e.g., Metro Communications Co. v. Ameritech Mobile Communications, Inc., 984 F.2d 739 (6th Cir. 1993) (cellular telephone system a service, not a commodity); Satellite Ass'n v. Continental Cablevision of Va., Inc., 586 F. Supp. 973 (E.D. Va. 1982), affd, 714 F.2d 351 (4th Cir. 1983), cert denied, 465 U.S. 1027 (1984); TV Signal Co. of Aberdeen v. American Tel. \& Tel. Co., 462 F.2d 1256 (8th Cir. 1972) (attachment space on utility poles is not a commodity); National Communications Assoc., Inc. v. American Tel. \& Tel. Co., 808 F. Supp. 1131 (S.D.N.Y. 1992) (long distance voice telecommunication services are not commodities); Rankin County Cablevision v. Pearl River Valley Water Supply Dist., 692 F. Supp. 691 (S.D. Miss. 1988) (cable television is not a commodity within meaning of the RobinsonPatman Act); H.R.M., Inc. v. Tele Communications, Inc., 653 F. Supp. 645 (D. Colo. 1987) (same); TriState Broadcasting Co. v. United Press Int'l., Inc., 369 F.2d 268 (5th Cir. 1966) (news information service is not a commodity).

${ }^{224}$ B \& W Gas Inc. v. General Gas Corp., 247 F. Supp. 339 (N.D. Ga. 1965).

${ }^{225}$ See City of Kirkwood v. Union Elect. Co., 671 F.2d 1173 (8th Cir. 1982), cert. denied, 459 U.S. 1170 (1983); Town of Concord v. Boston Edison Co., 676 F. Supp. 396 (D. Mass. 1988), rev'd on other grounds, 915 F.2d 17 (1st Cir. 1990), cert. denied, 499 U.S. 931 (1991); Borough of Ellwood City v. Pennsylvania Power Co., 570 F. Supp. 553 (W.D. Pa. 1983); City of Gainesville v. Florida Power \& Light Co., 488 F. Supp. 1258 (S.D. Fla. 1980).

Cases holding that the sale of electricity does not involve sale of a commodity for RobinsonPatman Act purposes are City of Groton v. Connecticut Light \& Power Co., 497 F. Supp. 1040 (D. Conn. 1980), affd in part and rev'd on other grounds, 662 F.2d 921 (2d Cir. 1981); City of Newark v. Delmarva Power \& Light Co., 467 F. Supp. 763 (D. Del. 1979). 
of a commodity. ${ }^{226}$ The same concept would be involved in the sale of "wheeling" of power or "mere delivery" over local lines or pipelines to retail consumers. Similarly, the unbundling of products and services in the telecommunications industry will provide much more potential for Robinson-Patman Act cases when the product part of the service is at issue.

In addition, in the public utilities, especially with the unbundling of services, it is often problematic whether the two sales alleged to be discriminatory involve commodities of "like grade and quality." Unlike the sale of most commodities at which the Robinson-Patman Act was aimed, the sales of utilities often involve different combinations of factors. For example, is it clear that the sale of firm electrical service is of a different grade or quality from interruptible service? Similarly, is it obvious that network access is different than point-to-point service? No case law was found applying the Robinson-Patman Act to these issues in the new environment that now exists in these industries.

\section{Joint Ventures ${ }^{227}$}

In today's utility world, joint activity among otherwise independent companies is relatively common. Here joint ventures in the electric power industry will be analyzed in some depth because it is in that industry in which the concept has been most fully

${ }^{226}$ See, e.g., Alliance Shippers, Inc. v. Southern Pac. Transp. Co.. 673 F. Supp. 1005 (C.D. Cal. 1986) (transportation is not a commodity), affd, 858 F.2d 567 (9th Cir. 1988); TV Signal Co. of Aberdeen v. American Tel. \& Tel. Co., 462 F.2d 1256 (8th Cir. 1972) ("commodity" is restricted to products, merchandise, or other tangible goods); Baum v. Investors Diversified Servs., Inc., 409 F.2d 872 (7th Cir. 1969) ("commodity" refers to products as distinguished from services).

${ }^{227}$ A somewhat analogous area is presented by the need for network joint ventures in the credit card industry. In recent years there has been considerable attention to this area and the cases and commentary are relevant to one working in the public utility area. See, e.g., National Bancard Corp. (NaBANCO) v. Visa U.S.A., Inc., 779 F.2d 592 (11th Cir.), cert. denied, 479 U.S. 923 (1986); South Trust Corp. v. Plus System, Inc., __ F. Supp. __ (D.N. Ala. 1995); SCFC ILC, Inc., v. Visa U.S.A., Inc., 36 F.3d 958 (10th Cir. 1994). See generally, Baker, "Compulsory Access to Network Joint Ventures Under the Sherman Act: Rules or Roulette?" 1993 Utah L. Rev. 999; Carlton \& Frankel, "The Antitrust Economics of Credit Card Networks," 63 Antitrust L.J. 643 (Winter 1995). 
used. ${ }^{228}$ However, it should be noted that joint ventures may also be present now and in the future in both gas and telecommunications as well.

Joint ventures, as noted above, ${ }^{229}$ obviously involve an agreement, often among competitors, that frequently will involve some restraint of trade among the participants. The legality of the arrangement turns upon how much restraint of trade is involved, what other competition is present, and the justification for the joint venture and whether that particular restraint is necessary to accomplish a legitimate goal. ${ }^{230}$ Even if the joint venture itself is legal, its provisions will be looked at very carefully to determine whether the particular restraint of trade at issue is necessary to accomplish the goal of the joint venture and whether there are less restrictive alternatives.

There are at least three types of important joint ventures in the electric power industry that may pose problems. First there is the joint venture to build and operate large, expensive facilities. At one time construction of such facilities was a very important factor, as the economies of scale involved made it economically imperative that large, efficient base load generating facilities be built if a firm was to operate efficiently. ${ }^{231}$ Often, because of the expense and the timing of the need for new generation capacity, construction by a given utility could only be justified if the facility was jointly financed and operated by two or more systems. With the changes that have occurred in the industry in recent years, it would appear that the basic need for such

${ }^{228}$ For a general discussion of joint ventures in the electric power industry, see Cohn, "The Promise of Regional Coordination and Power Planning," 8 Nat. Res. \& Env't. (Winter 1994), 23; Rokach, "Antitrust in the Electric Utility Industry: Regional Transmission Groups," 14 J.L. \& Com. 39 (1994); Atwood, "Antitrust, Joint Ventures, and Electric Utility Restructuring: RTGs and Poolcos," presented at annual meeting of ABA Section of Public Utilities, August 7, 1995, published in 64 Antitrust L.J. 323 (1996); cf., Makhom, "Gas Pipeline Capacity: Who Owns It? Who Profits? How Much?" Pub. Util. Fort. (Oct. 1, 1994), 17.

${ }^{229}$ See notes 69-74, supra, and accompanying text.

${ }^{230}$ Piraino, "Reconciling Competition and Cooperation: A New Antitrust Standard for Joint Ventures," $35 \mathrm{Wm}$. \& Mary L. Rev. 871 (1994) (this article contains an excellent review of the cases and authorities in this area of antitrust law); Jorde \& Teece, "Innovation, Cooperation and Antitrust," 4 High Tech. L.J. 1 (1989).

${ }^{231}$ See Meeks, "Concentration in the Electric Power Industry: The Impact of Antitrust Policy," 72 Colum. L. Rev. 64 (1972); Federal Power Commission, National Power Survey (1964); Federal Power Commission, National Power Survey (1970). 
joint ventures in construction of large generating units is less important, at least for the moment. However, existing joint ventures must be adaptable into a more competitive market environment in such a way that the antitrust laws will not be violated.

The second form of joint venture of importance is that involving simple power pooling. ${ }^{232}$ Involved is an agreement among neighboring systems to interconnect facilities for the exchange of power, serving the need for emergency and backup, as well as providing the availability of economy energy sharing among the participants. This pooling requires agreement on control of transmission and distribution facilities, exchange of information regarding costs of production, coordination of new construction of generating capacity and delivery systems, agreement on the requisite interconnections, and coordinated monitoring of line flow and power movements to maintain reliability and the security of the participating systems.

Such power pools have become very common since the 1960 s, dictated in part by the economics and technology that systems faced and the very aggressive policies of the FPC/FERC. Today virtually all systems are interconnected to at least a minimal extent and participate at some level in these joint ventures. Very significant efficiencies that redound to the benefit of consumers are achieved by such activity. However, these contractual arrangements, unlike those about to be discussed, do not include completely integrated operation. Each firm maintains essentially independent operations, coordinating with the joint venture similarly to what would occur in any complex vertical supply or purchase situation.

Finally, and most important today, are the joint ventures that more or less fully integrate the participating independent systems for most operating purposes. These are simply more sophisticated pooling arrangements than those just discussed. Such agreements delegate a large degree of responsibility for operations to the joint venture operating managerial team or by contract to an independent system operator (ISO). On

${ }^{232}$ For a description of a power pool, see New England Power Pool Agreement, 56 F.P.C. 1562 (1976), affd, Municipalities of Groton v. FERC, 587 F.2d 1296 (D.C. Cir. 1978). For a general discussion of power pooling approaches, see Charles F. Phillips, Jr., The Regulation of Public Utilities, Chapter 13 (3d ed., Public Utilities Reports 1993). 
its face this type of integration clearly raises some potential antitrust problems. But such joint ventures can also provide very substantial public interest benefits. ${ }^{233}$

Given the large diversity of generating capacity potentially available in such a joint venture, ${ }^{234}$ by incrementally loading first the cheapest available generating capacity to meet the incremental demand considering all the circumstances, large cost savings can result. The potential for lowering the price to consumers, increasing the reliability of the system, and using the whole system more efficiently is very substantial. Moreover, reserve capacity can be provided much more efficiently and emergency conditions dealt with more easily. Finally, transmission capability can be used to optimize delivery of power to off-system purchasers much more easily if one controlling system operator (perhaps an ISO) has access to a large network of lines to balance power flow. Thus the basic justification, in the public interest, for such complex operating joint ventures is very high.

${ }^{233}$ See, generally, Jorgensen \& Felder, "New England Power Pool: A Bridge to Competition," Pub. Util. Fort. 47 (July 1, 1995)

A good, currently important example of such joint ventures are the "regional transmission groups" (RTGs) being formed in the industry. These have been strongly encouraged by the FERC (Policy Statement Regarding Regional Transmission Groups, 58 Fed. Reg. 12,626 [1993], 18 C.F.R. § 2.21) and arguably by Congress in the legislative history of the EPAct of 1992 . They are viewed as the primary means of gaining universal access to the necessary transmission network to establish a truly competitive wholesale market in electric power generation. See, Rokach, "Antitrust in the Electric Utility Industry: Regional Transmission Groups," 14 J.L. \& Com. 39 (1994); Cohn, "The Promise of Regional Coordination and Power Planning," 8 Nat. Res. \& Env't. (Winter 1994), 23; Brand, "Breaking the Bulk-Power Bottlenecks," Pub. Util. Fort. (March 15, 1995), 21; Atwood, "Antitrust, Joint Ventures, and Electric Utility Restructuring: RTGs and Poolcos," presented at annual meeting of ABA Section of Public Utilities, August 7, 1995, published in 64 Antitrust L.J. 323 (1996). See generally, Green, "A New Generation of Electric Utility Cases Emerge," 7 Antitrust 28 (ABA Section on Antitrust Law Fall/Winter 1992).

${ }^{234}$ The diversity relates to fuel source, operating cost variation, size, location to load, and many other factors. Thus hydro-generated power and, perhaps, (depending upon how one calculates operating costs) nuclear power have very high sunk costs in capital investment, but relatively low operating costs. On the other hand, hydro power may be somewhat dependent upon long-term weather conditions and nuclear upon safety factors not present in other generation methods. Diesel and natural gas-fired units may be small and very versatile but have relatively high operating costs, depending upon the market in petroleum-based fuels at the time.

Finally, since point-to-point, true, physically isolated transmission is still not completely feasible in most instances, relative location of generation to load may affect the efficient choice of generation source. It may now be technologically possible through the use of Flexible AC Transmission Systems (FACTSs) to control the exact flow of electricity over the network to a greater extent than in the past, but as a practical matter, such control is expensive, still difficult to manage, and perhaps not cost justified. Rather, the interconnected network must, for the time being, be viewed as a commons, where contributions to it and takes from it affect all of the other parties to the network operation. 
It has to be recognized that most of these same efficiencies can be had by formal vertical integration into one corporate entity, as illustrated by such large, integrated systems as American Electric Power or the Southern Company, to name two. However, such formal integration to achieve these efficiencies also entails integration at other levels where diversity of ownership and management may still be possible and desirable. Moreover, the size of such large industrial amalgamations may introduce their own "firm" inefficiencies. Thus, of the two options available to achieve the efficiencies in the business of generation loading and transmission, the joint venture may be the preferred route. ${ }^{235}$

It would appear that there is little doubt that these various forms of joint ventures often can be justified under the antitrust laws because of the efficiencies created. ${ }^{236}$ Moreover, in general, there does not appear to be a way of achieving these efficiencies in a way that poses less of a threat to competition. Since they are the direct result of networking and integrating very large facilities and very complex distribution systems, they can probably be achieved alternatively only by formal integration of ownership, clearly from an antitrust point of view a more, not less, restrictive alternative. Thus, the inquiry shifts to the terms of the joint venture, not the joint venture itself.

${ }^{235}$ [J]oint ventures may pose less of a threat to competition than a merger involving the same parties. The antitrust enforcement agencies have permitted some joint ventures to proceed in circumstances in which they had or would have challenged a merger of the same parties. These decisions were grounded in the belief that restrictions on the scope and duration of joint ventures limit their anticompetitive effects. Unlike mergers, joint ventures may maintain the participants' status as independent competitors outside the framework of the collaborative effort.

"PLI Conference Explores Ins and Outs of Federal Agencies' Antitrust Enforcement," 63 Antitrust \& Trade Reg. Rep. (BNA) No. 1591, at 615, 623 (Nov. 19, 1992) (comments of Joseph Kattan) as quoted in Piraino, "Reconciling Competition and Cooperation: A New Antitrust Standard for Joint Ventures," $35 \mathrm{Wm}$. \& Mary L. Rev. 871 (1994).

${ }^{236}$ See Department of Justice, Antitrust Division comments to FERC, discussed in Eaton, "Recent United States Department of Justice Actions in the Electric Utility Industry," 9 Conn. J. Int'l. L. 857 (1994); also discussed in Hovert, "The Enforcer," Publ. Util. Fort. (Feb. 15, 1994) 10. See generally, Green \& Bouknight, "Electric Utility Antitrust Issues in an Era of Bulk Power Market Competition," 8 Nat. Res. \& Env't. 20 (Winter 1994); Cohn, "The Promise of Regional Coordination and Power Planning," 8 Nat. Res. \& Env't. 23 (Winter, 1994). For an in-depth review of a pooling agreement, see Municipalities of Groton v. FERC, 587 F.2d 1296 (D.C. Cir. 1978).

On February 22, 1996, The Department of Justice issued two business review letters stating that the Department had no objection to joint ventures forming real-time tracking markets for electric power. See 70 Antitrust \& Trade Reg. Rep. (BNA) No. 1751, at 233-34 (Feb. 29, 1996). 
Joint venture agreements may, however, pose problems in both the wholesale market for generation and also in the retail market, where the energy is sold from the network. In this sense, the joint venture forms a bottleneck through which all transactions at both the market level "above" and the market level "below" are potentially affected. Therefore, arrangements must be looked at very carefully to assure that any restraint of trade involved goes no further than necessary to capture the legitimate benefits of the joint venture at the transmission level.

The first problem that may arise is restrictions on membership or, in other words, access to the joint venture. As pointed out earlier, access to bottleneck facilities has been one of the clearest areas of antitrust concern in the public utility industries, at least since the Otter Tail case in 1972. ${ }^{237}$ Thus, denial of full participation in the joint venture to any qualified system will raise problems, if the joint venture is in fact significantly beneficial and if the entity seeking access can show any injury to competition, in any of its forms: direct at either the wholesale or retail level, franchise, or perhaps yardstick..$^{238}$ Of course, the firms seeking participation must be qualified and agree to reasonable terms of participation. ${ }^{239}$ However, those qualifications and terms must not be discriminatorily applied and probably have to be justified as truly necessary to the successful operation of the joint venture. The terms of the participation should be able to be varied to reflect the contribution to the joint venture that the applicant brings. For example, the terms applicable to an independent generator should arguably be different from the terms for a fully integrated generation, transmission, distribution system.

A second area of concern involves price fixing. Obviously, in such a joint venture there must be agreement on the formula for distributing costs and payments among the

${ }^{237}$ Otter Tail Power Co. v. United States, 410 U.S. 366 (1973). Though Otter Tail did not involve a joint venture, the legal issues are the same. The issues raised concerning access to essential facilities are discussed in the next section.

${ }^{238}$ See generally, Piraino, "Reconciling Competition and Cooperation: A New Antitrust Standard for Joint Ventures," 35 Wm. \& Mary L. Rev. 871, 924 (1994).

${ }^{239}$ In Northwest Wholesale Stationers, Inc. v. Pacific Stationery \& Printing Co., 472 U.S. 284 (1985), the Supreme Court recognized that reasonable membership restrictions in a cooperative organization should be upheld when they are "substantially related to the efficiency-enhancing or procompetitive purposes that otherwise justify the [joint venture's activities]". 
members of the joint venture for use of the various individually owned facilities dedicated to the joint venture. Thus, for transactions within the group there must be price fixing. However, such price setting is no different than that found legal in cases such as $\mathrm{BML},{ }^{240}$ where the price fixing was merely an ancillary aspect of carrying out the main purpose of the enterprise. It can be justified as essential to accomplishing the primary goal of the joint venture, the integrated operations at the cheapest possible cost. ${ }^{241}$ On the other hand, any agreement on the price at which the independent members of the joint venture will buy from or sell to others, outside the parameters of the joint venture, would probably not be necessary to accomplish the purposes of the joint venture. Therefore, any agreement upon the price of such transactions with those outside the joint venture could be a violation of Section One.

Similarly, any attempt to define or restrict the nature or the quality of the product or service being delivered to or from outsiders would have to be justified by an essential need related to achieving the joint activity, such as technical compatibility. Moreover, a collusive agreement not to deal with outside parties would require some special circumstance directly related to the heart of the joint venture's technical ability to operate; for example, a threat to the integrity/security of the network.

Finally, exchange of information can raise antitrust problems to the extent that it can facilitate overt or tacit price collusion. ${ }^{242}$ On the other hand, very detailed cost, capacity and other information must be exchanged in a sophisticated pooling joint venture in order to get the maximum efficiencies and in order to maintain reliability and integrity of the systems. The precedent in this area permits sharing of information to

${ }^{240}$ Broadcast Music, Inc. v. Columbia Broadcasting Sys., Inc., 441 U.S. 1 (1979). See also, Eaton, "Recent United States Department of Justice Actions in the Electric Utility Industry," 9 Conn. J. Int'l. L. 857, 866 (1994).

${ }^{241}$ By contrast, the price setting aspects did not appear to be essential to the joint selling agency challenged in Virginia Excelsior Mills, Inc. v. FTC, 256 F.2d 538 (4th Cir. 1958), although that case, and others like it, may also be distinguishable on the ground that, on balance, the benefits derived from the joint venture did not outweigh the anticompetitive effects.

${ }^{242}$ See notes $59-60$, supra. 
the extent that the need can be technically justified. It seems clear here that some possibility of misuse of the information to facilitate a restraint of trade is tolerable given the strong public benefit of such joint activity. However, any exchange that exceeds the need presented by the justification will put the joint venture in jeopardy. This seems especially critical given the likely market structure in parts of these industries and the accompanying strong possibility of tacit or oligopoly pricing.

\section{Access and the Essential Facilities Doctrine ${ }^{243}$}

In a number of public utility contexts one runs into a demand by one firm for access to a "bottleneck" facility of another firm or group of firms. The basic approach to this problem arises in two different antitrust contexts but has been handled very similarly. Under Section One of the Sherman Act the issue comes up when a group of firms, such as under a transmission or generation pooling agreement (as just discussed) refuses to deal with a firm that wants access to the benefits of the pool. Such a refusal by the group may constitute an unreasonable restraint of trade violative of Section One.

Alternatively, the issue can arise when a single firm controls an essential link for a product or service to reach its market. Section Two of the Sherman Act then becomes the legal focus. The defendant is claimed to have monopoly power because of its control over the essential facility and a refusal to deal on fair terms - to accord

\footnotetext{
${ }^{243}$ See generally, Meeks, "Concentration in the Electric Power Industry: The Impact of Antitrust Policy," 72 Colum. L. Rev. 64 (1972); Werden, "The Law and Economics of the Essential Facility Doctrine," 32 St. Louis U. L.J. 433 (1987); Baker, "Compulsory Access to Network Joint Ventures under the Sherman Act: Rules or Roulette?" 1993 Utah L. Rev. 999 (1993); Stevens, "Antitrust Law and Open Access to the NREN," 38 Vill. L. Rev. 571 (1993); Larson, Kovacic \& Mudd, "Competitive Access Issues and Telecommunications Regulatory Policy," 20 J. Contemp. L. 419 (1994); Lyon \& Hackett, "Bottlenecks and Governance Structures: Open Access and Long-term Contracting in Natural Gas," 9 J.L. Econ. \& Org. 380 (1993); Edgar, "The Essential Facilities Doctrine and Public Utilities: Another Layer of Regulation?" 19 Idaho L. Rev. 283 (1992-93); Ratner, "Should There Be an Essential Facility Doctrine?" 21 U.C. Davis L. Rev. 327 (1988).
} 
reasonable access to the essential facility - may constitute the "monopolization" aspect of a Section Two offense. ${ }^{244}$

The legal issues raised in these two contexts have come to be known as the essential facilities doctrine. ${ }^{245}$ The prerequisites of the application of the doctrine are frequently present in the utility contexts. Both historically and in the foreseeable future there have been, and will continue to be, pockets of natural monopoly in all three industries. Thus, in electricity, access to transmission and local distribution facilities will continue to pose the kind of bottleneck that makes access essential if there is to be any competition at any level of the industry. ${ }^{246}$ Similarly, at least for the time being, the same is true of the local loop needed to render telecommunication services to ultimate customers. ${ }^{247}$ In the gas industry, also, the local distribution facilities for delivering gas

${ }^{244}$ The possession of monopoly power and its use to injure possible competition are the essential elements of a Section Two offense. See notes 90-91, supra, and accompanying text.

${ }^{245}$ The issue was first referred to as the "essential facilities doctrine" apparently in Hecht v. ProFootball, Inc., 570 F.2d 982, (D.C. Cir. 1977), cert. denied, 436 U.S. 956 (1978). See, Werden, "The Law and Economics of the Essential Facility Doctrine," 32 St. Louis U. L.J. 433 (1987). However, the doctrine has its antecedents in a long line of cases starting with United States v. Terminal R.R. Assoc. of St. L., 224 U.S. 383 (1912). In the public utility field, the doctrine has been used or alluded to in a host of cases. The lower court judge relied upon the "bottleneck" doctrine, as it is sometimes called, in an alternative holding in the Otter Tail case. United States v. Otter Tail Power Co., 331 F. Supp. 54 (D. Minn. 1971), affd, 410 U.S. 366 (1973). While Justice Douglas does not expressly mention the doctrine in the Supreme Court's affirmance of the case, it certainly underlies his analysis.

The doctrine was explicitly relied upon in finding a possible violation in Judge Greene's ruling on the defendant's motion for summary judgment in the AT\&T case, preceding the settlement decree. United States v. American Tel. \& Tel. Co., 524 F. Supp. 1336, 1352-53 (D.D.C. 1981). The doctrine also formed the heart of the decision finding that AT\&T had violated Section 2 of the Sherman Act in the MCI case. $\mathrm{MCl}$ Communications v. American Tel. \& Tel. Co., 708 F.2d 1081 (7th Cir. 1982), cert. denied, 464 U.S. 891 (1983).

${ }^{246}$ In an interesting case, the court held that a Section 2 monopolization charge was successfully pled when the plaintiff alleged that the defendant had denied the use of its telephone poles to run plaintiff's television cable lines. TV Signal Co. v. American Tel. \& Tel. Co., 462 F.2d 1256 (8th Cir. 1972). The court did not mention the essential facilities doctrine but the reasoning is essentially the same.

${ }^{247}$ As noted elsewhere, this monopoly is beginning to break down with the advent of cellular phone, satellite transmission, and multiple wires (cable television and telephone) to some customers. Nevertheless, in many settings real competition at other levels of the industry is very limited without access to the local loop. Moreover, at best, we may be limited to a tightly structured oligopoly market.

See also Waterman," Vertical Integration and Program Access in the Cable Television Industry," 47 Fed. Comm. L.J. 511 (1995). 
to the consumer are usually a monopoly, constituting an essential facility to have competition at other levels of the industry. Even long distance pipeline transportation is often still a natural monopoly or, at best, a tight oligopoly. ${ }^{248}$ Thus, the abuse of power by a firm or group of firms that controls the bottleneck facility can, if unimpeded, control other levels of the industry.

It is now generally agreed that in order to have a violation of the essential facilities doctrine four elements are necessary: (1) there must be control of an essential facility by the defendant(s); (2) the firm seeking access must be unable practically or reasonably to duplicate or circumvent the essential facility; (3) there must be a denial of access on a reasonable basis; (4) it must be feasible to accord access to the firm seeking it. ${ }^{249}$ The first two elements relate directly to the question whether the facility is essential. Does the plaintiff really need access in order to reach the market - are alternative methods available? It is not necessary apparently that the other alternatives may not be as good or as cheap — the defendant has the right to enjoy the economic rents, as opposed to monopoly rents, resulting from its ability to perform better than others. ${ }^{250}$ The constraint must be an external constraint that precludes duplicating the

${ }^{248}$ FERC Order 636 is aimed specifically at opening full access to the pipeline system to make possible competition at other levels of the industry. FERC Order 636 (April 8, 1992), 57 Fed. Reg. 13,267, 1992 WL 75263 (F.R.).

${ }^{249}$ Paraphrased from the MCl case, MCl Communications v. American Tel. \& Tel. Co., 708 F.2d 1081, at 1132-33 (7th Cir. 1982), cert. denied, 464 U.S. 891 (1983).

${ }^{250}$ See, e.g., City of Anaheim v. Southern Cal. Edison Co., 955 F.2d 1373, 1380-1381 (9th Cir. 1992) (defendant, using full capacity, not required to grant plaintiff access simply so plaintiff could achieve savings); City of Vernon v. Southern Cal. Edison Co., 955 F.2d 1361, 1367 (9th Cir.) (noting that plaintiff's demand that defendant turn over its facility to plaintiff simply because plaintiff could save money by obtaining cheaper power "stands the essential facility doctrine on its head"), cert. denied, 506 U.S. 908 (1992); City of Chanute v. Williams Natural Gas Co., 955 F.2d 641, 648 (10th Cir.) ("As the word 'essential' indicates, [plaintiff] must show more than inconvenience, or even some economic loss; [plaintiff] must show that an alternative to the facility is not feasible"), cert. denied, 506 U.S. 831 (1992); Florida Cities v. Florida Power \& Light Co., 525 F. Supp. 1000, 1006-07 (S.D. Fla. 1981) (plaintiff's showing that access to defendant's facilities would be more economical to plaintiff not sufficient to establish the presence of an essential facility). 
facility and over which the plaintiff cannot have any control, such as the physical terrain in the St. Louis terminal case or the physical laws that make electric transmission and distribution a declining cost function at virtually all levels of use. A number of recent cases in the public utility area have failed on this part of the test. The courts found that alternative transmission or other facilities were in fact present or could have been reasonably constructed. ${ }^{251}$

The third element in the test is aimed at making sure that the defendant has really denied access. A number of recent cases in the utilities industries have involved this question. The courts have consistently held that the access need not be accorded on the plaintiff's terms, so long as the defendant's offer is reasonable. For example, the courts have held that a retail distribution electric company seeking access to a transmission network in order to receive wheeled power, may not be able to dictate the points of access or demand full network access, as opposed to a convenient drop point for the power..$^{252}$

Finally, the courts have consistently held that when a defendant has a legitimate business reason for refusing access, not related simply to preventing competition, the

${ }^{251}$ See, e.g., City of Anaheim v. Southern Cal. Edison Co., 955 F.2d 1373, 1380-1381 (9th Cir. 1992) (there was "no dearth" of available power; plaintiff's possible savings at expense of defendant is not enough to create an essential facility); City of Malden, Mo. v. Union Elec. Co., 887 F.2d 157, 161-163 (8th Cir. 1989) (jury finding that alternatives to defendant's transmission line existed not against the weight of the evidence where defendant's testimony showed at least five reasonable alternatives); City of Chanute v. Williams Natural Gas Co., 955 F.2d 641, 649 (10th Cir.) (plaintiff must show that alternative to facility is not feasible, not merely that there is inconvenience or some economic loss), cert. denied, 506 U.S. 831 (1992); City of Mt. Pleasant, lowa v. Associated Elec. Coop., Inc., 838 F.2d 268 (8th Cir. 1988) (plaintiff city had received at least three bids on last contract and defendant cooperative had never denied any request to wheel power); Florida Fuels, Inc. v. Belcher Oil Co., 717 F. Supp. 1528, 1533 (S.D. Fla. 1989) (plaintiff's evidence failed to show that it was unfeasible to duplicate defendant's facilities); Illinois, ex rel. Burris v. Panhandle E. Pipe Line Co., 935 F.2d 1469 (7th Cir. 1991) (dealing with access to pipeline gas), cert. denied, 502 U.S. 1094 (1992).

252 See, e.g., City of Vernon v. Southern Cal. Edison Co., 955 F.2d 1361 (9th Cir.) ("reasonable" access to defendant's facilities need not take the form of plaintiff's desired access), cert. denied, 506 U.S. 908 (1992); Gas Util. Co. of Ala. v. Southern Natural Gas Co., 825 F. Supp. 1551, 1574 (N.D. Ala. 1992) (no antitrust violation where evidence showed that defendant offered access other than in form plaintiff requested), affd, 996 F.2d 282 (11th Cir. 1993), cert denied, 114 S. Ct. 687 (1994). 
refusal to deal can be justified. ${ }^{253}$ Thus, the courts have held that where the integrity of the system is at stake, access can be refused, at least unless conditions can be put upon the access that avoids the technical problem. Refusal to agree to competitively neutral policies to protect others' interests may be grounds for exclusion. Unwillingness to pay reasonable costs of access will justify exclusion. Finally, the courts have generally held that access that would injure or impose greater costs on the base consumers of the essential facility system may justify a refusal to accord access. ${ }^{254}$

It can be expected that as partial deregulation continues in the public utilities, we will see much of the essential facilities doctrine. Since elements of strategic monopoly power will almost certainly continue to exist and since a refusal to share access to these bottleneck facilities will harm the potential for competition to develop in other aspects of the industries, one can expect many antitrust disputes to arise over the essential facilities doctrine.

${ }^{253}$ See, e.g., City of Anaheim v. Southern Cal. Edison Co., 955 F.2d 1373, 1381 (9th Cir. 1992) (utility had a legitimate business reason for denying access); City of Vernon v. Southern Cal. Edison Co., 955 F.2d 1361, 1366 (9th Cir.) (defendant legitimately concerned about retail rates in making its facilities access decisions), cert. denied, 506 U.S. 908 (1992); Illinois, ex rel. Burris v. Panhandle E. Pipe Line Co., 935 F.2d 1469 (7th Cir. 1991), cert. denied, 502 U.S. 1094 (1992) (refusal to deal is permitted given takeor-pay contract obligations); City of Chanute v. Williams Natural Gas Co., 743 F. Supp. 1437 (D. Kan. 1990), affd, 955 F.2d 641 (10th Cir.), cert. denied, 506 U.S. 831 (1992) (defendant established a legitimate business reason for its decision to close pipeline to interim open access, precluding finding of intent to monopolize); but see, Consolidated Gas Co. of Fla. v. City Gas Co., Inc. of Fla., 665 F. Supp. 1493 (S.D. Fla. 1987), aff'd, 880 F.2d 297 (11th Cir. 1989), cert. granted and judgment vacated after parties settled, 499 U.S. 915 (1991) (refusal to deal constituted an unlawful maintenance of monopoly power absent any legitimate justification).

In Gas Utils. Co. of Ala. v. Southern Natural Gas Co., 825 F. Supp. 1551 (N.D. Ala. 1992), affd, 996 F.2d 282 (11th Cir. 1993), the court held that the defendant had a legitimate business reason when plaintiff sought taps to its gas line that would put it in competition with the defendant and other purchasers from the defendant. To this author, the court's treatment of what is "a legitimate business reason" as including a competitive harm goes too far.

${ }^{254}$ See, e.g., City of Anaheim v. Southern Cal. Edison Co., 955 F.2d 1373, 1381 (9th Cir. 1992) (defendant's cost savings, resulting in a savings to all of its customers, serves the public interest and "gives even more weight to the propriety of the refusal"); City of Vernon v. Southern Cal. Edison Co., 955 F.2d 1361, $1366 \mathrm{n.9}$ (9th Cir.) (defendant can legitimately refuse access that will affect its rates to the detriment of its customers), cert denied, 506 U.S. 908 (1992); City of College Station v. City of Bryan, 1996 WL 86747, 1996 Trade Cas. I 71,280 (S.D. Tex. 1996). The last case is particularly interesting because it involves one municipal system suing another municipal system and a municipal power agency for refusal to wheel on reasonable terms. The court held that it was not a violation for the defendants to refuse to wheel except at a price that reflected their fully imbedded costs.

THE NATIONAL REGULATORY RESEARCH INSTITUTE - 90 


\section{Mergers and Acquisitions}

Mergers of business entities or acquisition of significant assets from another firm are dealt with in the antitrust laws primarily under Section Seven of the Clayton Act, ${ }^{255}$ although, as noted earlier, such transactions may also be covered by Section One and Two of the Sherman Act. Nevertheless, it must be remembered that Section Seven seems to apply a more demanding standard of illegality to mergers and acquisitions ${ }^{256}$ than the standards for illegality under Section One ${ }^{257}$ and Section Two. ${ }^{258}$ Significant mergers and acquisitions in the gas, electric, and telecommunications industries are also subject to approval by the respective federal regulatory agency and usually by applicable state regulatory agencies. ${ }^{259}$ These agencies today will take into account the antitrust concerns involved in the merger as part of the "public interest" regulatory standard. The Justice Department usually registers with the applicable agency its view regarding the antitrust issues, as well. As a result, no merger or acquisition case filed initially in the courts has been found in the last several years. ${ }^{260}$ The deference to agency expertise and regulatory preeminence in this area has been dominant.

25515 U.S.C. $\S 18$. A general discussion of merger and acquisition law is contained in notes 129149 , supra, and accompanying text. This section is referred to as the Celler-Kefauver Act as a result of the extensive amendment of the original act in 1950.

${ }^{256}$ That is, "may be substantially to lessen competition or tend to create a monopoly."

257 That is, "unreasonable restraint of trade."

${ }^{258}$ That is, "monopolize or attempt to monopolize."

${ }^{259}$ Public Utility Holding Company Act, $\S 9,15$ U.S.C. $\S 79 i$ (applicable to any public utility holding company in all three industries under consideration here); Natural Gas Act, $\S 7,15$ U.S.C. $\$ 717 f$; Federal Power Act, $\S 203(a), 16$ U.S.C. $\S 824 b ; 47$ U.S.C. $\S 310$ (d) (requiring permission to transfer license to use radio waves).

${ }^{260}$ A strong argument can be made, in fact, that Congress originally intended all merger and acquisition matters to be handled under the regulatory regime, starting in the respective agencies. There is language in Section 7 of the Clayton Act that would appear to exempt mergers and acquisitions that fell under administrative agency jurisdiction. In a strained interpretation of the statute, however, the Supreme Court did not accept this position. See California v. Federal Power Comm'n, 369 U.S. 482 (1962). As a result there remains dual jurisdiction, at least in theory. As noted in the text, the Justice Department has largely abstained from bringing cases outside the regulatory context. 
Moreover, private treble damage actions in the courts are very difficult for a plaintiff to bring. The Supreme Court has held that for a competitor, the most likely plaintiff in a merger or acquisition situation, to have standing to bring a case, the plaintiff must prove injury, not to itself as a competitor, but to the competitive market process. ${ }^{261}$ Thus, a merger which produces efficiencies that will allow the new firm to offer lower prices may cause injury to a competitor, but that will not constitute injury to competition. On the other hand, if the merger will lead the new firm to charge higher prices noncompetitive prices - the plaintiff cannot be injured. In fact, the competitor ought to be better off. Only in those cases where the plaintiff can prove injury as a result of an increased ability to leverage or foreclose will a merger or acquisition arguably be subject to private challenge.

In the telecommunications industry, since 1982, any merger or acquisition involving a post-consent decree company emerging from the old AT\&T, at least as a practical matter, had to be approved by the court pursuant to the consent decree. ${ }^{262}$ As a practical matter this has precluded any merger or acquisition activity between any of the competing or potentially competing operating companies or between the rebuilt AT\&T and any of the operating telephone companies. The court has approved acquisitions that amount to market extension mergers, involving one of the companies subject to the decree moving into an area of business or service unrelated to the

\footnotetext{
${ }^{261}$ Cargill, Inc. v. Montfort of Colo., Inc., 479 U.S. 104 (1986); Brunswick Corp. v. Pueblo Bowl-O-Mat, Inc., 429 U.S. 477 (1977).

262 United States v. American Tel. \& Tel. Co., 552 F. Supp. 131 (D.D.C. 1982), aff'd mem., sub nom., Maryland v. United States, 460 U.S. 1001 (1983). Cases seeking modification of the settlement decree to allow mergers, acquisition or joint activity, include: United States v. Western Elec. Co., 154 F.R.D. 1, reconsidered, 158 F.R.D. 211 (D.D.C. 1994), aff'd, 46 F.3d 1198 (D.C. Cir. 1995); United States v. Western Elec. Co., 1990 WL 126492, 1990-2 Trade Cases If 69,139 (D.D.C. 1990).

With the passage of The Telecommunications Act of 1996, Pub. Law 104-104, signed into law on Feb. 8,1996 , the status of consent decree as it applies to such issues as mergers and acquisitions is not clear. The judge handling the case has indicated that the Act may have mooted such issues but has asked the parties to submit briefs on the point. The United States Department of Justice has now moved to terminate the consent order completely in light of the new statute. 70 Antitrust \& Trade Reg. Rep. (BNA) No. 1752, at 256 (March 7, 1996). Of course, such mergers and acquisitions would still fall under the potential coverage of Section 7 of the Clayton Act.
} 
antitrust concerns that had given rise to the original case. Moreover, as noted earlier, ${ }^{263}$ the attempt by Congress to keep the telephone operating companies out of the television cable industry has been struck down by the courts on Constitutional grounds.

In all segments of the telecommunications industry today we see a restructuring by merger and acquisition. The industry is so volatile that it is almost impossible to assess the anticompetitive threats, if any, posed by this realignment. Many of the mergers can be designated as vertical mergers, or market extension mergers. Few thus far have had significant horizontal components, particularly at the local regulated service level. In the rest of the industry, as it is evolving, the prevailing view among the confronted agencies and many commentators, to date, is that there is sufficient competition or potential competition that most mergers are not thought sufficiently dangerous to be challenged by antitrust enforcers. Also, thus far, the regulatory agencies have not been very concerned by any anticompetitive threat and have generally viewed the mergers as neutral or efficiency creating. ${ }^{264}$ When there have been concerns, modification of the proposal that satisfied the agencies were arrived at.

Potentially, however, there is one area of concern. For the time being, at least, local operating telephone companies still have a great deal of control over access to ultimate customers by controlling the local loop, particularly for those customers with relatively restrictive budget constraints. Mergers or acquisitions that enhance that

\footnotetext{
${ }^{263}$ See note 15, supra. See also Sigal, "Challenging the Telco-Cable Cross-Ownership Ban: First Amendment and Antitrust Implications for the Interactive Information Highway," 22 Fordham Urb. L.J. 207 (1994).

${ }^{264}$ See, e.g., SBC Communications, Inc. v. FCC, F.3d (D.C. Cir. 1995) and the related antitrust suit, United States v. American Tel. \& Tel. Co., No. 94-CV01555 (D.D.C.). These cases involved the acquisition by AT\&T of McCaw Cellular Communications, Inc. The Justice Department had agreed to a consent decree, 59 Fed. Reg. 44,159 (1994), but, initially, it was not accepted by Judge Greene, reviewing the acquisition under the AT\&T consent decree. Upon reconsideration, he allowed the acquisition to go forward and this was affirmed by the Court of Appeals. The United States Department of Justice has now moved to discuss its cases in light of the 1996 Act. 70 Antitrust \& Trade Reg. Rep. (BNA) No. 1752, at 256 (March 7, 1996). See also, cases cited in note 262, supra. See also, United States v. TeleCommunications, Inc., No. 94-0948 (D.D.C. 1994) (involving merger between two firms with substantial cable markets and substantial interests in popular video programming; settled by consent decree, 59 Fed. Reg. 24,723); United States v. Primestar Partners, L.P., No. 93 Civ. 3913 (S.D.N.Y. April 4, 1994), 58 Fed. Reg. 33,994 (1994) (involving a joint venture of several large cable systems); In Re Boulder Ridge Cable TV, FTC Docket No. C-3537 (Oct. 21, 1994) (consent decree approved but conditioned on removal of a territorial limitation clause, prohibiting competition between the participants). But cf., Waterman, "Vertical Integration and Program Access in the Cable Television Industry," 47 Fed. Cornm. L.J. 511 (1995).
} 
control, or that increase the ability to leverage that power into control of other markets, may pose a significant antitrust concern.

In the electric power industry there have also recently been a large number of proposed mergers between integrated power companies. ${ }^{265}$ These cases have been handled almost entirely within the FERC and the SEC (under the Public Utility Holding Company Act [PUHCA], where applicable), with the only court involvement being appeals from the agency decisions. ${ }^{266}$

One must first address a jurisdictional issue. Under section 203 of the Federal Power $\mathrm{Act}^{267}$ the FERC has jurisdiction over all mergers of electric utility companies that fall under the Act's coverage. Many mergers in this industry also fall within the PUHCA ${ }^{268}$ because they involve a structure in which one company holds the ownership of another company. ${ }^{269}$ Given this dual jurisdiction, an issue has existed for several years as to which agency is the primary authority for passing on the antitrust aspects of a merger. Recently one court has resolved this question. In City of Holyoke Gas \&

${ }^{265}$ See, e.g., Northeast Utils. Serv. Co. v. FERC, 993 F.2d 937 (1st Cir. 1993), affd, Northeast Utils. Serv. Co., and New Hampshire Pub. Serv., 56 FERC \ 61,269 (1991); Utah Power \& Light Co. \& PacifiCorp, 45 FERC ๆ 61,095 (1988), aff'd in part, rev'd in part sub nom., Environmental Action, Inc. v. FERC, 939 F.2d 1057 (D.C. Cir. 1991), on remand, 128 P.U.R.4th 113 (1991); Entergy Serv., inc. and Gulf States Util. Co., 65 FERC ๆ 61,332 (1993); Midwest Power Systems, Inc. and lowa-III. Gas \& Elect. Co., 71 FERC $\Uparrow 61,386$ (1995).

${ }^{266}$ See, e.g., Northeast Utils. Serv. Co. v. FERC, 993 F.2d 937 (1st Cir. 1993). See generally, Spiwak, "Expanding the FERC's Jurisdiction to Review Utility Mergers," 14 Energy L.J. 385 (1993); Kalis, "The Role of Antitrust Law in Promoting Competition in Electricity Generation and Transmission," $11 \mathrm{~J}$. Energy, Nat. Res. \& Envt'l. L. 287 (1991); Michael, "Electric Utility Mergers: The Answer or the Question?" Pub. Util. Fort. 20 (Jan.1, 1996); Burkhart, "Evolving FERC Merger Policy Delays 'ALTUS' Deal," Pub. Util. Fort. 37 (Feb. 1, 1996).

The Justice Department has also indicated that it has been devoting increased resources to antitrust enforcement with regard to the increașe in merger activity in the electric power industry. See Remarks of David S. Turetsky, Deputy Asst. Attorney General, Antitrust Division, at Edison Electric Institute Conference, reported in Utility L. Rep. (CCH), at 4 (Newsletter No. 1153, Feb. 22, 1996).

26716 U.S.C. Section 824a. For a general discussion of this jurisdictional issue, see Spiwak, "Expanding the FERC's Jurisdiction to Review Utility Mergers," 14 Energy L.J. 385 (1993).

${ }^{268}$ See 15 U.S.C. Section $79 j$.

${ }^{269}$ This structure is frequently dictated, if for no other reason, by the home state of the utility. That state often insists that companies subject to its regulatory jurisdiction be incorporated in the state. 
Electric Dept. v. S.E.C., ${ }^{270}$ the Securities and Exchange Commission (SEC) had deferred to the FERC on questions of the public interest taking into account the antitrust questions once it was satisfied that the PUHCA standards had been met. The court approved of this approach.

Mergers in the electric power industry today are hard to characterize as either horizontal or vertical, since they typically have elements of both. They also illustrate market extension mergers. Typically involved are adjacent systems that historically have not been in direct competition. They also typically are operationally related in a power pool or similar joint venture for reliability and economy energy sharing. At one level these mergers illustrate a formal integration of what had been a contractual integration. This makes them essentially market extension mergers, with an element of vertical merger included. But today, with the advent of competition or potential competition at the generation level, such mergers usually also involve the elimination of horizontal competition among potential generation competitors. However, treated as horizontal mergers alone, these mergers have generally been thought not to pose much of a problem. ${ }^{271}$ So long as access to sufficient transmission capacity is available, ${ }^{272}$ the wholesale market for generation appears to be so large and diverse, on both the supply and demand sides, that one may need not worry as much about any significant concentration problem.

The FERC in recent years has been vitally interested in preserving and promoting the development of that wholesale competition. To that end, as noted earlier, ${ }^{273}$ the FERC has proposed a generic open access policy on transmission,

${ }^{270} 972$ F.2d 358 (D.C. Cir. 1992). This was one chapter in the many involving the acquisition of New Hampshire Public Service by Northeast Utilities, pursuant to the bankruptcy of the former.

${ }^{271}$ However, there is some indication that this attitude may be changing. See Remarks by David S. Turetsky, cited note 266 , supra.

${ }^{272}$ A competitive market for generation is absolutely dependent upon access to the transmission network required to get the power from seller to purchaser. As will be discussed below, the FERC has been pursuing an aggressive policy to open access. The use of the antitrust laws to force access is treated in the discussion of the essential facilities doctrine, notes $244-255$, supra, and accompanying text.

${ }^{273}$ See note 24 , supra. 
similar to its restructuring of the natural gas industry. ${ }^{274}$ It had even earlier used its merger approval power to further that policy objective whenever possible by insisting that the merger agreement include free access provisions before Commission approval would be forthcoming. The courts so far have gone along with this approach. ${ }^{275}$

It has pursued this policy recognizing two potential anticompetitive harms if such access is not assured. First the FERC is concerned that the combined firm might use control of the transmission network to insist that wholesale customers buy their needs from the company rather than from alternative generation sources that would need to wheel the power over the merged firm's lines. Second there has been concern that the combined firm might buy power from other generation sources and then resell it at inflated prices to wholesale customers, reflecting its monopoly power over the essential transmission network.

This approach by the FERC reflects the concern that the transmission bottleneck would permit merging firms to engage in successful leverage. As such, the essential facilities doctrine, as well as the more general concern regarding the use of leverage in these partially regulated, partially competitive situations, is served by the FERC approach, while permitting the mergers, which may well enhance efficiencies. The policies of the FERC on this issue fit well within the prevailing approach to mergers and acquisitions under Section Seven of the Clayton Act. One would therefore expect the antitrust enforcement agencies and the courts applying strictly antitrust law, as opposed

${ }^{274}$ Congress, in the Energy Policy Act of 1992, see note 23, supra, gave the FERC the power to order wheeling. It has used that power to serve its policy mission to open access to transmission in cases in which a potential wholesale buyer has sought wheeling. See, e.g., Florida Municipal Power Agency v. Florida Power \& Light Co., 67 FERC $\Uparrow 61,167,1994$ WL 182802 (1994).

The Commission has recently moved even further in this direction by proposing a Rule that would require all systems to provide open transmission access. This proposed rulemaking has come to be known as the Mega-NOPR. FERC Notice of Proposed Rulemaking, 60 Fed. Reg. 17,662 (1995) (to be codified at 18 C.F.R. $§ 35$ ) (proposed April 7, 1995). See "FERC Seeks More Fully Competitive Wholesale Electric Power Market," Util. L. Rep. (CCH) No. 1108 (April 13, 1995).

${ }^{275}$ Northeast Utils. Serv. Co. v. FERC, 993 F.2d 937 (1st Cir. 1993); Utah Power \& Light Co. \& PacifiCorp, 45 FERC $\uparrow 61,095$ (1988), aff'd in part, rev'd in part sub nom., Environmental Action, Inc. v. FERC, 939 F.2d 1057 (D.C. Cir. 1991), on remand, 57 FERC 1 61,363 (1991). The FERC's first decision is discussed in detail in Kalis, "The Role of Antitrust Law in Promoting Competition in Electricity Generation and Transmission," 11 J. Energy Nat. Res. \& Envtl. L. 287, 307-11 (1991). 
to regulatory law, to continue to be a presence in the background rather than a main player.

Turning to the natural gas industry, interestingly despite the restructuring of the market promoted by the FERC, there has been relatively little movement toward consolidation by merger or acquisition. ${ }^{276}$ The legal principles will be the same as those discussed with regard to telecommunications and electricity should such a trend develop. The potential is there for either horizontal mergers, among pipelines for example; conglomerate market extension mergers, for example among adjoining local distribution systems; or vertical, among suppliers and deliverers of gas. But except in a few special instances, no movement in the direction of consolidation seems present.

${ }^{276}$ Although note should be taken of a recent FTC action. The agency moved to stay the acquisition by a pipeline of a $\mathbf{5 0}$ percent ownership interest in its only competitor serving the Salt Lake City area. The FTC was concerned that the acquisition might allow the pipeline to reestablish its former monopoly position as the only pipeline serving the market. Questar Corp. et al., Court Complaint, Federal Trade Commission, File No. 961 0001, Dec. 27, 1995, reported in Util. L. Rep. (CCH) at 3 (Newsletter No. 1147, Jan. 11, 1996). 



\section{CHAPTER 6}

\section{DEFENSES OF SPECIAL RELEVANCE IN THE PUBLIC UTILITY INDUSTRIES}

\section{The State Action Doctrine 277}

The basic premise of the state action doctrine, first articulated in Parker v. Brown, ${ }^{278}$ rests upon the determination that Congress in adopting the antitrust laws did not intend to preempt direct state regulation schemes that might lead to incompatibility with the antitrust laws. Rather, the assumption was that Congress had intended the antitrust laws to apply only in the absence of some comprehensive state regulatory program aimed at accomplishing the same goals, that is, serving the consumer interest at the cheapest possible price. In the context of public utility regulation, the state action doctrine has consistently been held to exempt conduct of the regulated utilities that might otherwise violate the antitrust laws, if the conduct is subject to adequate state regulation. The doctrine provides a very effective defense to many possible antitrust actions by public utilities. ${ }^{279}$

277 The state action doctrine is the subject of another study currently under contract by The National Regulatory Research Institute. Therefore, the treatment here will be brief and somewhat superficial.

${ }^{278}$ Parker v. Brown, 317 U.S. 341 (1943). See generally, 1 Areeda \& Turner, supra, note 26, at fiा 207-18; Garland, "Antitrust and State Action: Economic Efficiency and the Political Process," 96 Yale L.J. . 486 (1986); Jorde, "Antitrust and the New State Action Doctrine: A Return to Deferential Economic Federalism," 75 Cal. L. Rev. 227 (1987); Gifford, "The Antitrust State-Action Doctrine After Fisher v. Berkeley," 39 Vand. L. Rev. 1257 (1986); Page, "Antitrust, Federalism, and the Regulatory Process: A Reconstruction and Critique of the State Action Exemption after Midcal Aluminum," 61 B.U. L. Rev. 1099 (1981).

279 The antitrust laws also do not apply to the states acting in their sovereign capacity. Parker $v$. Brown, 317 U.S. 341 (1943). However, they do apply to lower governmental units, such as municipalities and power districts. See, e.g., City of Lafayette v. Louisiana Power \& Light Co., 435 U.S. 389 (1978); Community Communications Co. v. City of Boulder, 455 U.S. 40 (1982). However, to blunt the impact of the treble damages provision of the antitrust laws, in 1984 Congress passed the Local Government Antitrust Act, Pub. Law No. 98-544, 98 Stat. 2750 (1984), 15 U.S.C. $\S \S 234-36$, which limits the remedy against a qualifying lower governmental entity to an injunction. 
The Supreme Court, in a series of cases in recent years, has articulated the prerequisites for a successful use of the state action doctrine. ${ }^{280}$ The defendant must show: (1) that there is a clearly articulated regulatory policy under state law that leads to an inconsistency with the antitrust law as applied in the particular situation; and (2) that there is active, significant state supervision over the conduct that is involved in the alleged antitrust violation. ${ }^{281}$

It is important to note that as deregulation, or relaxed regulation, occurs in these industries, this defense will be available in fewer and fewer situations. This follows both from the change in the "clearly articulated state policy to substitute regulation for competition" and from the likely absence then of "active state supervision of the activity."

\section{The Filed Rate Doctrine}

As pointed out earlier, ${ }^{282}$ the courts have clearly held that there is no general defense to the antitrust laws simply as a result of extensive regulatory control. Nor have the courts generally recognized any doctrine of deference to the regulatory agencies as the appropriate body to interpret the application of the antitrust laws to the

${ }^{280}$ In addition to the City of Lafayette, and City of Boulder, cited in the preceding note and the Ticor, and Town of Hallie cases cited in the next note, see, e.g., Patrick v. Burget, 486 U.S. 94 (1988); Fisher v. City of Berkeley, 475 U.S. 260 (1986); S. Motor Carriers Rate Conference, Inc. v. United States, 471 U.S. 48 (1985); Hoover v. Ronwin, 466 U.S. 558 (1984); California Retail Liquor Dealers Ass'n v. Midcal Aluminum, Inc., 445 U.S. 97 (1980); New Motor Vehicle Bd. of Cal. v. Orrin W. Fox Co., 439 U.S. 96 (1978); Bates v. State Bar of Ariz., 433 U.S. 350 (1977); Cantor v. Detroit Edison Co., 428 U.S. 579 (1976); Goldfarb v. Virginia State Bar, 421 U.S. 773 (1975)

281 The Court's most recent, extensive treatment of this part of the test is in FTC v. Ticor Title Ins. Co., 504 U.S. 621 (1992), in which the court held that the state officials regulating the activity must undertake specific supervision of the activity. A mere rubber stamp approach was not adequate. But see, DFW Metro Line Servs. v. Southwestern Bell Tel., Corp., 988 F.2d 601 (5th Cir.), cert. denied, 114 S.Ct. 183 (1993) (state supervision was adequate); TEC Cogeneration, Inc. v. Florida Power \& Light Co., 1994 WL 242149 (S.D. Fla. 1994) (state supervision not complete), rev'd on this issue, F.3d 1996 WL 75650 (11th Cir. 1996) (also held that Noerr-Pennington Doctrine applied).

The Court has been somewhat less demanding on this aspect of the test when the defendant is a lower governmental agency, which has been delegated responsibility for conducting the activity in the public interest. See Town of Hallie v. City of Eau Claire, 471 U.S. 34 (1985).

${ }^{282}$ See notes 2-7, supra, and accompanying text. 
industry that the particular agency regulates. However, in one area the Supreme Court ${ }^{283}$ and the lower courts ${ }^{284}$ have traced out a related, limited defense applicable only to private treble damage actions. It has come to be referred to as the "filed rate doctrine".

The doctrine, in its broadest terms, holds that a rate legally on file with an administrative agency with jurisdiction to set the rate, cannot be collaterally attacked as unreasonable in an antitrust case. Thus, if the antitrust claim involves any question regarding the reasonableness or appropriateness of a rate, the filed rate doctrine precludes the consideration of that antitrust issue. The courts have consistently held that such an attack upon the reasonableness or appropriateness of the rate must be pursued in an action upon the rate itself in the relevant regulatory agency. ${ }^{285}$ As a practical matter, the doctrine precludes any private antitrust damage action where the amount of damages hinges upon a difference between the "rate on file" and what would have been the appropriate rate without the alleged antitrust violation. Thus, for example, a predatory pricing claim may run squarely into the filed rate doctrine - the challenged rate is on file and if damages are sought as the remedy, the filed rate doctrine will come into play.

The two reasons for the doctrine's exception to what would otherwise be the application of the antitrust laws rests upon two interrelated ideas, as articulated by the courts:

${ }^{283}$ The case in which the Supreme Court first announced this doctrine was Keogh v. Chicago \& N.W. Ry. Co., 260 U.S. 156 (1922) (involving ICC-established rates). See also, Montana-Dakota Utils. Co. v. N.W. Pub. Serv. Co., 341 U.S. 246 (1951) (involving FPC-set electric rates); Arkansas La. Gas Co. v. Hall, 453 U.W. 571 (1981) (involving FPC gas rates); Square D Co. v. Niagara Frontier Tariff Bureau, Inc., 476 U.S. 409 (1986) (involving ICC-set motor carrier rates); cf., Nantahala Power \& Light Co. v. Thornburg, 476 U.S. 953 (1986); Mississippi Power \& Light Co. v. Mississippi, ex rel. Moore, 487 U.S. 354 (1988).

${ }^{284} \mathrm{MCl}$ Telecommunications Corp. v. Graphnet, Inc., 881 F. Supp. 126 (D.N.J. 1995); County of Stanislaus v. Pac. Gas \& Elec. Co., 1994-2 Trade Cas. (CCH) I 70,782 (E.D. Cal. 1994), and again, 1996 Util. L. Rep. (CCH) I 14,082 (D.C. Col. 1996); Florida Mun. Power Agency v. Florida Power \& Light, 839 F. Supp. 1563 (M.D. Fla 1993), rev'd and remanded for factual hearing, 64 F.3d 614 (11th Cir. 1995) (discussed in detail below); Hilling v. Northern States Power Co., 1990 WL 597044 (D. Minn. 1990).

\footnotetext{
${ }^{285}$ Of course, the courts would generally have jurisdiction over the issue on an appeal from the agency decision.
} 
(1) Assuming the regulated firm was charging the filed (that is, approved) rate, that was the only legal rate. The buyer had paid no more than the legal rate and therefore the buyer was not injured in its business or property, a prerequisite of a damage remedy under the antitrust laws.

(2) The agency was the only legal body that could in the first instance establish a legal rate (that is, the courts did not have this power), and therefore, the courts in a collateral action, such as an antitrust suit, do not have the power to declare a rate illegal or, more importantly perhaps, to decide what a hypothetical legal rate would be. The latter determination would be critical to determining the appropriate damages.

A good example of the reach and potential complexity of the doctrine is illustrated in Florida Mun. Power Agency v. Florida Power and Light. ${ }^{286}$ In that case the plaintiff was a municipally-owned agency, organized to sell economic and reliable power to its twenty-six municipal system members. The agency members purchased from the defendant, Florida Power and Light (FP\&L), power at wholesale for resale in their respective territories. The agency sued for damages and an injunction, charging violations of the antitrust laws. The antitrust complaint was directed at FP\&L's refusal to sell power to the Agency on a "network" basis rather than on a "point-to-point" basis. ${ }^{287}$ FP\&L was providing the point-to-point service to the plaintiff under a tariff on file with the FERC. The plaintiff was seeking network service, allowing the members to have ready access to economical energy by being able to integrate its various facilities using FP\&L's transmission network.

The trial court dismissed the part of the case that sought damages for the refusal to render the service. The court reasoned that exactly the same service was involved,

${ }^{286} 839$ F. Supp. 1563 (M.D. Fla. 1993), rev'd and remanded for factual hearing, 64 F.3d 614 (11th Cir. 1995).

${ }^{287}$ Point-to-point service describes the normal sale where the power is coming from a designated source and being delivered at a particular drop point. This has nothing to do with the physics of how the power actually moves but since all power is commingled and fungible, one normally does not have to get more complicated by tracking actual loop flows.

Network service, on the other hand, is where the buying customer simply receives power off the network at any drop point and from any source or sources that happen to be furnishing power to the network at the time. 
whether the power was delivered on a point-to-point basis or a network basis, and that therefore the only thing involved in the damages aspect of the case was the appropriateness of the point-to-point rates. ${ }^{288}$ The court held that the attack was upon the appropriateness of the rate on file at the FERC and thus the antitrust claim for damages had to be dismissed. ${ }^{289}$ The court did state that it would not have dismissed the claim for an injunction, since that would not have entailed an attack upon the filed rate. However, the injunctive remedy had become moot because the FERC had apparently already ordered FP\&L to offer the network service to the plaintiff in an agency proceeding. ${ }^{290}$

On appeal to the Eleventh Circuit, the court reversed the grant of summary judgment on the damage claim. The court held that determining whether point-to-point service was the same product as network service was a factual question and could not

${ }^{288}$ A strong argument can be made, of course, that point-to-point service and network service are quite different products and that for network service the company had no rate on file. Thus, the filed rate doctrine did not apply. In fact, in this period of unbundling and redefinition of service and products in these industries, the lower court's treatment here of the two services as being the same does appear to be wrong. See the discussion of this issue in connection to tying law, supra, note 213-18, and accompanying text. Moreover, the court of appeals seems to have disagreed with the lower court on this point, thinking that it was at least an open question of fact.

On the other hand, for purposes of the damage remedy it is not quite clear how the damages could have been calculated except by constructing a hypothetical reasonable rate for the network service and then subtracting the hypothetical reasonable rate from the filed reasonable rate, exactly the kind of decision that the filed rate doctrine is designed to avoid. The court of appeals held, however, that if the court on remand found the services to be distinct, and that FP\&L had violated the antitrust laws, it could calculate damages based upon an estimate of what the rate for network service would have been.

${ }^{289}$ As the court put it: Since FMPA could have obtained the service it sought at any time, [under the point-to-point tariff rates] its claim for damages reduces to a claim that the rate for transmission on file with FERC was unreasonable.

Florida Municipal Power Agency, supra, note 286.

${ }^{290}$ See note 274 , supra.

Obviously the rule does not normally apply when the remedy sought is an injunction, since the validity of the filed rate is not usually in question. Note however, that if the injunction directly attacks the rate itself, the suit still will be dismissed, even though the remedy sought is an injunction. See Hilling v. Northern States Power Co., 1990 W.L. 597044 (D. Minn. 1990) (remedy sought was injunction on charging the filed rate). Moreover, one court has held that the filed rate doctrine only applies to a customer or seller challenging the rate it has been charged or received, that is, a vertical relationship. It does not apply to an antitrust case brought by a competitor on the basis that it was injured by a rate that violated the antitrust law. City of Groton v. Connecticut Light \& Power Co., 662 F.2d 921 (2d Cir. 1981). While the doctrine has been primarily applied in the federal courts, it has also been recognized in some state courts. See, e.g., Cullum v. Seagull Mid-South, inc., 322 Ark., 190, 907 S.W.2d 741 (1995). 
be decided on a motion for summary judgment. The court, while refusing to decide the issue, clearly implied that it thought point-to-point service and network service were two different animals. ${ }^{291}$

\section{Other Possible Defenses}

\section{Standing}

To sue under the antitrust laws, one must have standing. Of course, the federal government always has standing to enforce the statutes, as do the states in most situations acting in their parens patriae capacity. However, for a private plaintiff to sue under the antitrust laws, it must show that it has been injured in its business or property. ${ }^{292}$ Moreover the injury must be of a kind that the antitrust laws were designed to prevent. Thus cases may be dismissed because the plaintiff has either failed to plead or prove such injury. ${ }^{293}$

Moreover, the plaintiff must be directly injured by the alleged antitrust violation in order to have standing. The Supreme Court has held that an indirect purchaser, for example does not have standing. ${ }^{294}$ After some uncertainty, this rule has been applied

${ }^{291} 64$ F.3d 614 (11th Cir. 1995).

${ }^{292}$ See generally, Brunswick Corp. v. Pueblo Bowl-O-Mat, Inc., 429 U.S. 477 (1977); Gas Utils. Co. of Ala. v. Southern Natural Gas Co., 825 F. Supp. 1551 (N.D. Ala. 1992), aff'd, 996 F.2d 282 (11th Cir. 1973), cert. denied, 114 S. Ct. 687 (1994) (dealing with standing in a suit by wholesale buyer seeking access to pipeline in a bypass situation - held, no standing); Midwestern Waffles, Inc. v. Waffle House, Inc., 734 F.2d 705, (11th Cir. 1984) (no standing unless plaintiff has suffered antitrust injury); John Lenore \& Co. v. Olympia Brewing Co., 550 F.2d 495 (9th Cir. 1977) (no standing); Carter Hawley Hale Stores v. The Limited, 587 F. Supp. 246 (C.D. Cal. 1984) (target of a tender offer does not have antitrust standing); but see, Midland Telecasting Co. v. Midessa Television Co., 617 F.2d 1145 (5th Cir.), cert. denied, 449 U.S. 954 (1980) (refusal to carry plaintiff's VHF signal on its cable gives television station standing to sue).

${ }^{293}$ See, e.g., Gas Utils. Co. of Ala. v. Southern Natural Gas Co., 825 F. Supp. 1551 (N.D. Ala. 1992) (plaintiff's evidence that it would have in fact entered the industry as a competitor was too speculative); cf., North Carolina Electric Membership Corp. v. Carolina Power \& Light Co., 780 F. Supp. 322 (M.D.N.C. 1991)

${ }^{294}$ Illinois Brick Co. v. Illinois, 431 U.S. 720 (1977). The indirect purchasers doctrine, as the rule is referred to, also applies when a state is suing on behalf of ultimate consumers in its parens patriae capacity. See Illinois, ex rel. Burris v. Panhandle E. Pipe Line Co., 935 F.2d 1469 (7th Cir. 1991), cert. 
in the regulated public utility context, even though the plaintiff could show that the entire cost of the antitrust violation had been passed on to ultimate consumers as a result of rate regulation. ${ }^{295}$ However, if the suit is brought under state rather than federal antitrust law, and that law permits indirect purchasers to sue, the plaintiff may still recover. ${ }^{296}$

\section{Statute of Limitations}

The statute of limitations within which one must file an action to recover damages for violation of the antitrust laws is four years from the discovery of the injury. ${ }^{297}$ While the effects of many antitrust violations may continue to have repercussions beyond the statute of limitations, damage actions have been held available only if the conduct that specifically constitutes the elements necessary for the violation have occurred within the four year period. Thus, in North Carolina Electric Membership Corp. v. Carolina Power \& Light Co., ${ }^{298}$ the alleged predatory pricing that had occurred had ceased more than four years before the antitrust action was brought. The court held that although the plaintiff still suffered the consequences of the predatory pricing, which had made it financially impractical for the plaintiff to build

denied, 502 U.S. 1094 (1992).

295 Kansas v. Utilicorp United, Inc. 497 U.S. 199 (1990).

${ }^{296}$ See California v. ARC Am., Corp., 490 U.S. 93 (1989); Illinois, ex rel. Burris v. Panhandle E. Pipe Line Co., 935 F.2d 1469 (7th Cir 1991); Dunlap v. Colorado Springs Cablevision, Inc., 829 P.2d 1286 (Colo. 1992).

${ }^{297}$ The Clayton Act provides:

Any action to enforce any cause of action under sections $15,15 \mathrm{a}$, or $15 \mathrm{c}$ of this title shall forever be barred unless commenced within four years after the cause of action accrued. 15 U.S.C. $\S 15 b$.

${ }^{298} 780$ F. Supp. 322 (M.D.N.C. 1991). See also Kaw Valley Elec. Coop. Co. v. Kansas Elec. Coop., Inc., 872 F.2d 931 (10th Cir. 1989) (holding that statutory period starts to run from time of first refusal to deal and it does not fall within the continuing violation exception). 


\section{CHAPTER 6}

potentially competing generation and transmission facilities, it could no longer sue for damages. ${ }^{299}$

\section{Noerr-Pennington Doctrine}

Under this doctrine the courts have held that one cannot be held to violate the antitrust laws when the only conduct involved is petitioning an appropriate governmental body for political action, no matter how adverse to competition the sought after government action might be. ${ }^{300}$ Such activity is protected by the First Amendment right to free speech and the right to petition government. Thus, a utility defendant, whether as a matter of concerted action with others or in its capacity as a monopolist, may freely petition a governmental body for action that is destructive of competition, such as exclusive territories, for example. The courts have held, however, that where the petitioning of government is merely a sham to mask or shelter clearly violative conduct, the doctrine will not apply. ${ }^{301}$ Needless to say, the point at which legitimate political activity becomes sham activity is not at all clear.

299 One can argue with this court's decision, however. It makes it very difficult for a customer/ competitor system to ever recover for a predatory pricing violation. Granted that such legitimate suits may be rare, see discussion, supra, notes 102-05, 195-202, and accompanying text, but it may be unwise to dismiss such cases based upon the rationale underlaying this application of the statute of limitations. The problem is that the plaintiff will suffer no damages as a purchaser while the prices are at the predatory level. Then, when the prices are later increased to take advantage of the monopoly return possibilities, the statute of limitations will quickly run and in a case like North Carolina Electric Membership Corp. leave almost no damages to provide an incentive to use. However, the court did not dismiss the claim that the defendant had refused to deal with the plaintiff in violation of the antitrust law, and was continuing to do so. In this respect the case is similar to the Otter Tail case. See note 237, supra, and accompanying text.

${ }^{300}$ Eastern R.R. Presidents Conf. v. Noerr Motor Freight Co., 365 U.S. 127 (1961); United Mine Workers of Am. v. Pennington, 381 U.S. 657 (1965); See generally, 1 Areeda \& Turner, supra, note 26, at ITा 201-05; Bien, "Litigation as an Antitrust Violation: Conflict Between the First Amendment and the Supreme Court," 16 U.S.F. L. Rev. 41 (1981).

301 See California Motor Trans. Co. v. Trucking Unlimited, 404 U.S. 508 (1972); Otter Tail Power Co. v. United States, 410 U.S. 366 (1973); Professional Real Estate Investors v. Columbia Pictures Inds., Inc., 508 U.S. 49 (1993); MCl Communications Corp. v. American Tel. \& Tel., 708 F.2d 1081 (7th Cir.), cert. denied, 464 U.S. 891 (1983); Clipper Exxpress v. Rocky Mountain Motor Tariff Bureau, Inc., 674 F.2d 1252 (9th Cir. 1982), cert. denied, 459 U.S. 1227 (1983); cf., Allied Tube \& Conduit Corp. v. Indian Head, Inc., 486 U.S. 492 (1988). 


\section{CHAPTER 7}

\section{CONCLUSION}

In view of the rapidly changing nature of our public utility industries due to technological change and new thinking about the wisdom of pervasive regulation, it is clear that the application of the antitrust laws in these industries will increase in importance. Antitrust enforcement agencies and regulators must understand the impact of antitrust law in these somewhat different contexts. Without such an understanding, the public interest cannot be served. It is also of utmost importance for firms operating in these markets (many of which have officers who are accustomed to the semi-protection of the regulatory regime) to acquaint themselves with these different "rules of the road" as they break out into the previously unchartered territory of competition in these industries.

This report has attempted to provide an overview of the body of antitrust law and the theories that underlie its interpretation with particular concern for how it might be applied in the rapidly changing context of the traditional public utility industries. This report also has included a review of several special problems that have already surfaced or soon will, including a consideration of most of the recent antitrust case law involving these public utility contexts. 